Article

\title{
The Uses of Human Malleability: Images of Hellish and Heavenly Sojourns in Pre-Modern Burma
}

\author{
Lilian Handlin \\ Independent Scholar, Harvard University, Cambridge, MA 02138, USA; lilioscar@aol.com
}

Received: 21 March 2020; Accepted: 27 April 2020; Published: 7 May 2020

\begin{abstract}
For more than a millennium, Burmese donors sponsored elaborately decorated structures to publicize their allegiance to the Buddha's Dhamma in its Pali version, illuminating their understanding of the human predicament. The structures always featured décor informed by revered texts, the Buddha's words or Buddhavacana and its elaborators, that in the context of the biography of Gotama Buddha writ large, recalled numerous sub-chapters en route to Awakening. Throughout that immensely long timeframe, conceptions of retribution, recalling sojourns in various hells or heavenly mansions, remained constant. Their interpretation, however, moved with the times, reflecting the ever-shifting components of the Gotama saga designed to meet changing circumstances. The article explains why and how these two subjects sustained their influence, how their meanings changed, and how their visual interpretation reflected contemporaries' grasp of the future. The core argument asserts that behind the images was a socializing conditioning mechanism revealing this setting's ideational substructure. That substructure's lineaments exploited psychological and physiological assumptions regarding how humans functioned, harnessing emotions evoked by stories and images and utilizing fear as a form of societal control. The aim was to create what throughout Burmese history were called "the good people" —ideal subjects for a dhamma-governed society.
\end{abstract}

Keywords: Pagan; Burma; Pali Daw; niraya; vimānavathu; saṃvega; pasāda; hirī; ottappa

\section{Introduction}

The Dhammapada, a collection of verses, with its commentary that told stories connected with the verses, was one of the Pali texts featured in décor visible on the interiors and exteriors of structures sponsored by Burmese donors over the course of a millennium. Verse 15 reads, "Here he grieves, hereafter he grieves: the evil doer grieves in both existences. He grieves and he suffers anguish when he sees the depravity of his own deeds". The commentator associated these lines with the story of Cunda, a butcher who for 50 years tortured and slaughtered pigs. To begin with, he would beat them while still alive to soften their flesh, pour boiling water down their throat to cleanse their interiors, burn off their body hair, and cut their flesh to collect blood, all the while performing no good deeds. In time, the butcher's body was dotted with oozing canker sores, and he took to crawling around his abode, howling like a pig night and day, preventing neighbors from having a good night's rest. When the end was nigh, Cunda was literally roasted for seven days before being swallowed by Avīci hell, whose temperature the commentator described by quoting the monk Nāgasena's description of the hellfire's intensity to King Milinda in the widely circulated Milindapañho, Questions of King Milinda. The Dhammapada and the The Questions of King Milinda were, among others, for the Burmese, 'living' 
texts, attested by their presence in the public domain. They were visibly used, as opposed to other texts, which were perhaps available, but used by monastics only—as opposed to others on display. ${ }^{1}$

The use of such materials to enhance the significance of a sponsored endowment (Figure 1) illuminates the evolving contours of the Burmese sense of virtue, this society's understanding of the world, and, with it, the human condition. This article does not contend with the question of whether these practices and the ideational assumptions behind them-rituals, liturgies and habits of the heart-amount to a "religion". However defined, the term was unknown to the Burmese until very recent times. ${ }^{2}$

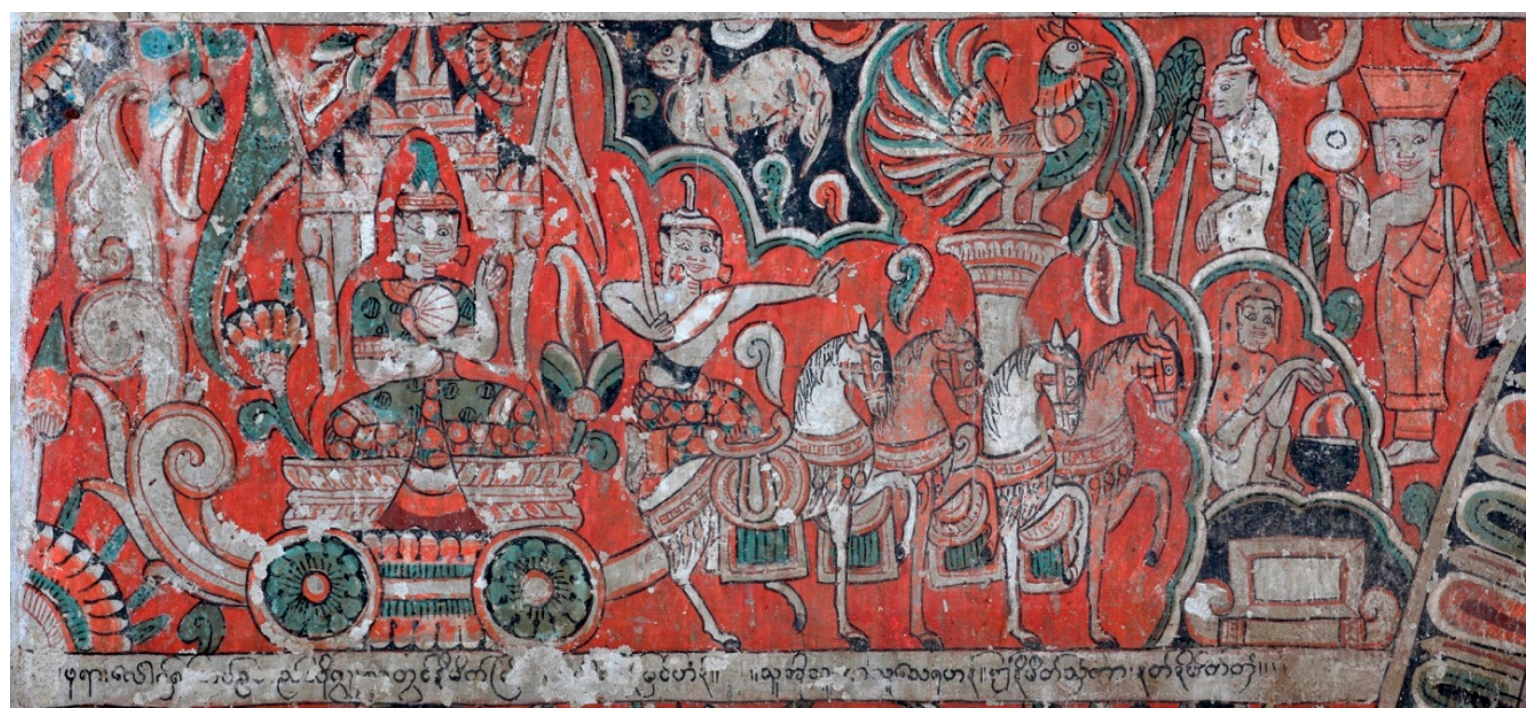

Figure 1. Salyingyi, 18th Century. The Four Omens. In the garden, the prince sees four beings, an old man, a sick man, a dead man and a recluse.

The moral of the story of Cunda, according to a later Burmese commentator, linked behavior to punishment, in this instance informed by his lack of two emotions that will be central to this essay: ottappa and samvega. Ottappa may be translated as fear, samvega as shock, which in the English vernacular is a 'holy shit' moment. Cunda failed to access these available antidotes against a future in hell. He lacked what others had and what worked for them, whatever it was that struck therapeutic terror into "virtuous [or good] people". Such people were shaken up when witnessing the butcher's punishment during his lifetime, which would be continued in the hereafter. Not attending to emotions like samvega or heeding one's inborn guardians like ottappa, were linked by the commentator to karma: "the cause of doing and its effect are the same". This sensibility, regardless of its interpretation, informed Burmese ideational history. How this notion shaped Burmese lives over the centuries remains to be unraveled. ${ }^{3}$

Shifts in how specific narrative components were imaged may serve as evidence of how such heavy-duty concepts embedded in this society's ideational substratum adjusted to daily circumstances. Evidence survives in extant endowments—see Figure 2, for a 18th century example. Visual narratives were one of this substratum's most sophisticated expressions, metamorphosing through time. This article focuses on several components embedded in them, to see how they and others changed.

1 Dhammapada Atthakathā as the commentary to Dhammapada, Cundasukarika Vatthu verse 15 (Burlingame 1921, vol. 28, p. 225ff). Samvegavatthudipani (Jagarabhivamsa 1986 (1348), In Burmese). On the significance of the distinction between the Pali canon and its actually used parts, see (Blackburn 1998; Collins 1998). Pagan is an excellent site to investigate this distinction. For a different treatment of this article's subject, see (Yian 2015).

2 On the broader issues, most recently, see (Schoeber 2008, pp. 255-67; De La Perriere 2009, pp. 185-210).

3 Samvegavatthudipani (Panatipata, 20, pp. 52-54). 
Recognizing variations enables the tracing of important ideational developments-which is valuable, as more conventional historical data are missing.

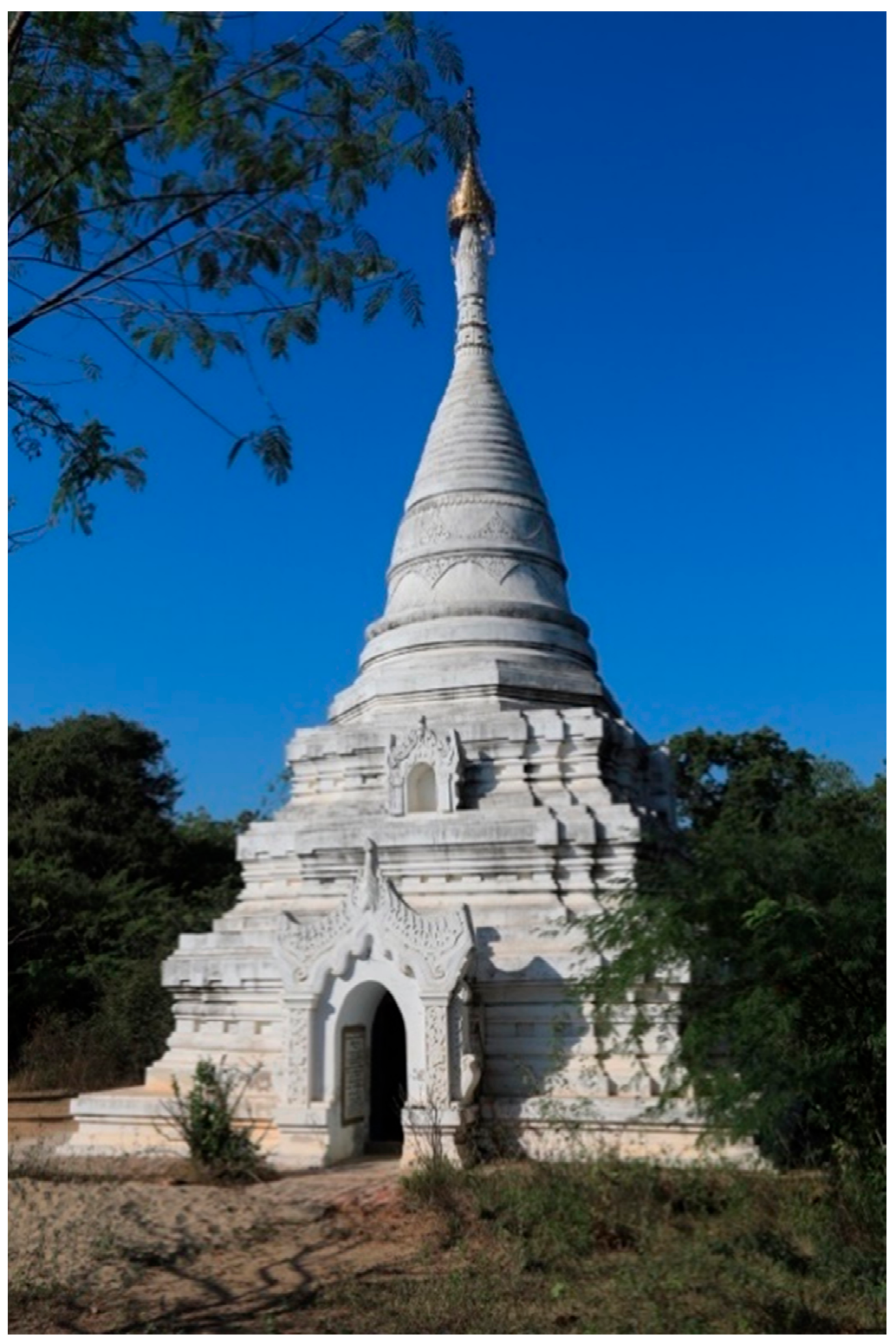

Figure 2. Salyingyi, 18th century-a typical medium sized endowment.

It was not only the meaning of key terms like Dhamma or samvega, that proved flexible, so did the narratives recast for the purpose of being seen. This was also true of their oral echoes, about which nothing is known except for what survives in a handful of extended donative inscriptions that became more prevalent by the 17th century. Changes in narratives' subcomponents indicate ideational developments, illuminating alterations in people's attitudes towards their lot. This is clearly seen in the treatment of the Four Omens or Four Signs that are a key component in narratives concerned with samvega and its resolution, calm or pasāda.

Depictions of the Four Omens appear clearly for the first time in an almost invisible location in the highest tier on the wall of an early Mon inscribed structure (completed in 1112 AD). The surviving sliver features an impressively weaponized entourage not associated with this highly private episode as narrated in the source from which the information to construct the image likely derived, the Pali Nidānakathā. In the latter only the inquisitive prince in the company of his charioteer ventures into the garden. The Mons' interpretation take suggests a textual source different from the one currently 
available in Pali and that, as will be shown, survived when the Burmese vernacular was used. This imagery perhaps explains a puzzling trope in the Pali Nidannakathā, where at each encounter it is reiterated that only Siddhārtha and the charioteer could see the omens, which sounds odd given that supposedly only they were present, although the veritable army of bystanders indicates otherwise. The later Pathamasambodhi, stories of the life of the Buddha composed in Southeast Asia, mentions the battalions that are said to be able to see the Omens. ${ }^{4}$

The popularity of the Four Omens increased considerably in the next two centuries as indicated by their new spatial location in the visual narratives. They descended from the structures' highest and thus less visible tiers to the lower and directly visible ones, situated next to different components, paralleling the changing allocation of space for the Buddha biography in general. These changes occurred at the same time as the growing dominance of Burmese-speaking ethnic groups and dynasties, which meant that most inscriptions were in the vernacular Burmese. By the 13th century, the Omens' importance was underscored by their presence even when the Buddha biography's frame numbers sometimes shrank.

The format of the Four Omens remained unstable; sometimes all four components appear, in other instances only one or two (Figure 3). Their location was also a movable feast, in several instances following immediately, for example, the encounter with the Brahmin predicting the baby's future. At other times the Four Omens appeared shortly after the Birth Episode as an introduction leading to The Great Departure, both interpretations omitting important intermediate episodes, hinting at what interpreters wanted to foreground.

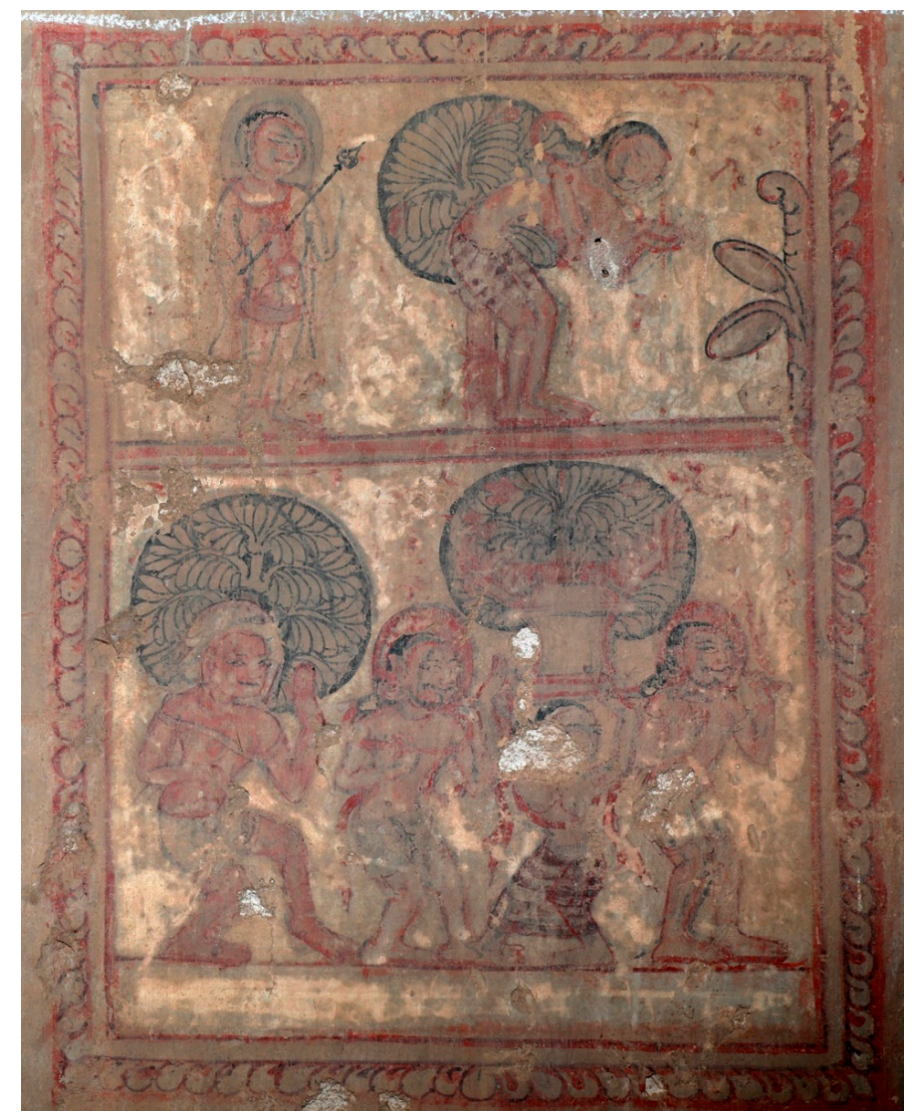

Figure 3. Pagan, Winido, 13th century, Endowment 659. The Four Omens, compressed into one frame, and featured, among numerous others, prince Siddhartha-Buddha Gotama biographical slivers. 
Like the image contexts, the visual narratives' written sources also moved with the times, since the Dhamma, given its users, was always in motion. (Figure 4) In later centuries, for example, unease about the lack of seeming interaction between the prince and what he was looking at during his garden escapades, prompted insertions. This could take the form of a conversation between Siddhārtha and the "rahan", the ascetic, even though the original Pali text emphasized that the "unreal" Omens were but a mirage conjured to hasten the prince's advancement to Awakening, attesting the power of the seen, for emotions like samvega and pasāda. In other cases, the meaning of the Omens could be reinforced by making images interchangeable. Thus, the dead Jūjaka in a Vessantara Jātaka image was made to resemble the Four Omen's dead man in another tier. The ever-plastic Pali terms were also in motion, likely shedding their Pagan era meaning. That meaning is restricted for us, given the meager evidence, to what the Pali texts themselves had to say, the images illustrating the episode and their contextual placement.

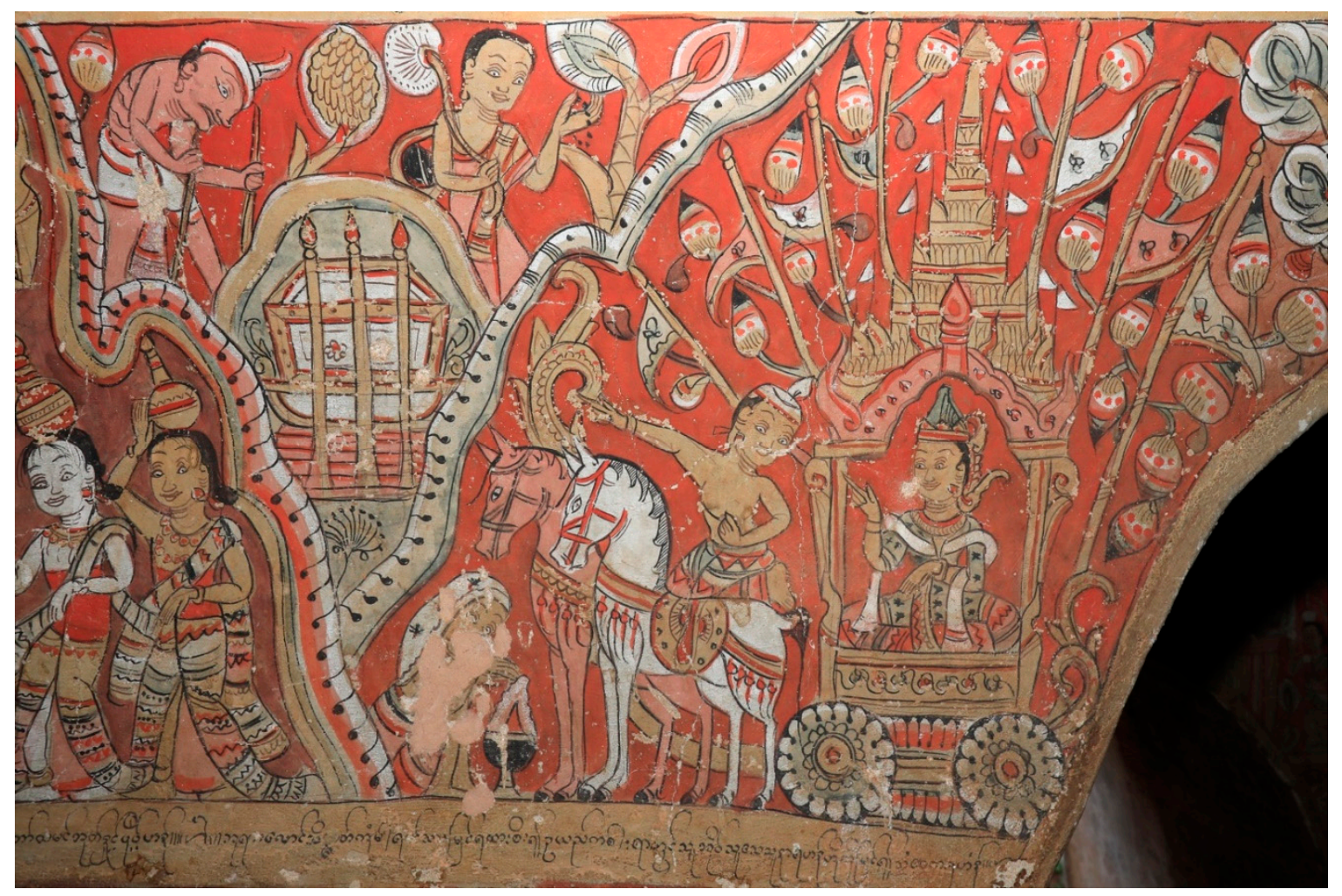

Figure 4. Anaint, Zedi Taw Taik, 18th century. Four Omens in a later interpretation.

Later centuries had their own take on the terms, the story and its context. (Figures 5 and 6). The accompanying army was restored to the visual narrative, soldiers by the 18 th century bearing European arms, with a foreigner positioned as Siddhārtha's bodyguard on the Mingala garden excursion. The appearance of foreigners in these paintings is not unique; for example, the hated Portuguese were often featured as the bad guys, the merchants about to drown, in a Mahājanaka Jātaka (539) interpretation, identifiable by their faces, head gear, as well as tunics. Elsewhere, Muslims were cast as defeated heretics, patterned after common images of what "Indians" were supposed to look like, and adding as an identifier a mosque rooftop highlighted by a crescent moon (a symbol of Islam), conveniently shown sinking into the ocean. ${ }^{5}$ 


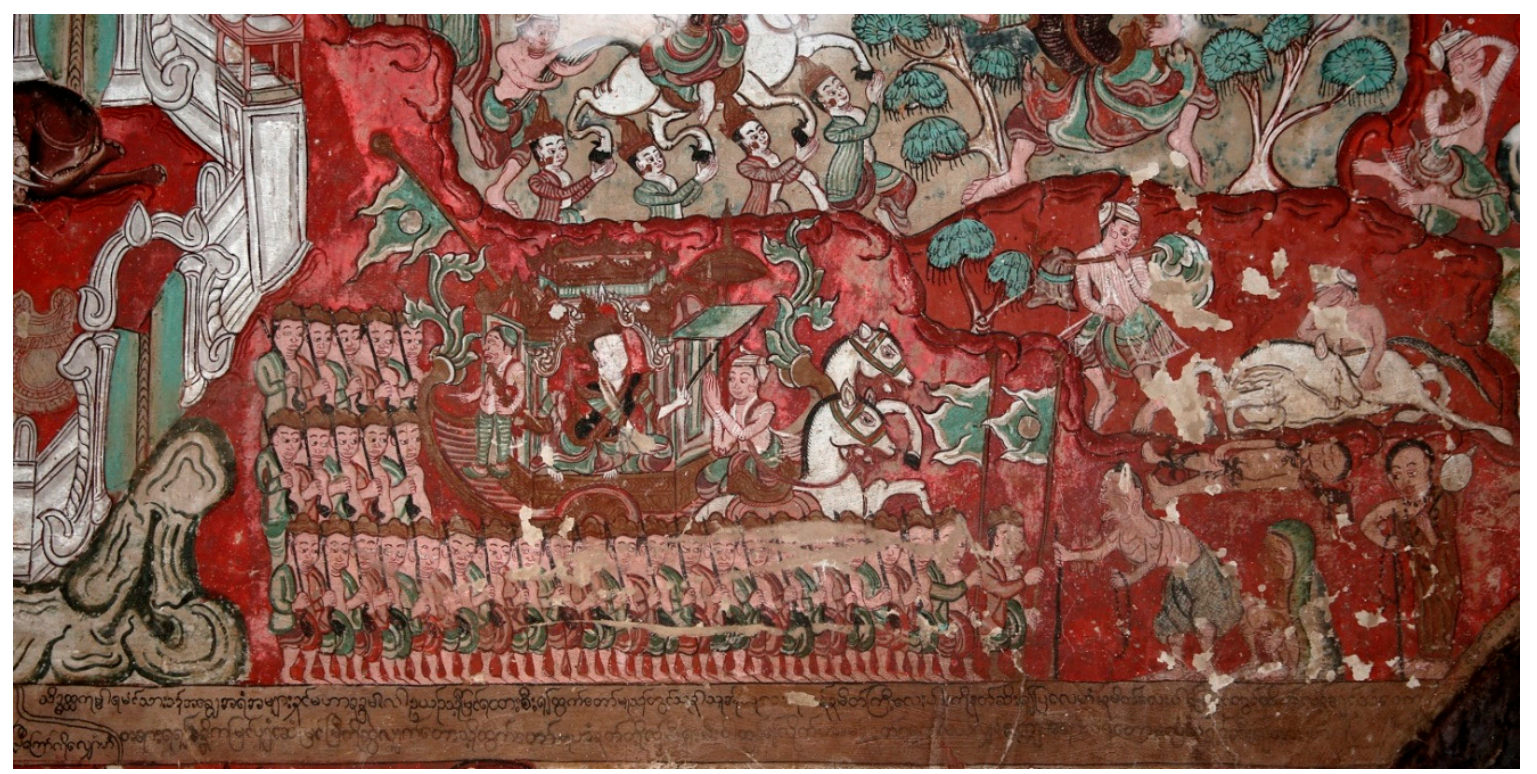

Figure 5. Amyint, Kuntaung Hpaya, 19th Century. Four Omens with embellishments-the dead man being attacked by crows, featuring also an immense army accompanying the garden sojourn, linked above to the Great Departure and, on the right side, the demise of the horse and the always-weeping charioteer dismayed by his master's choice to abandon courtly life.

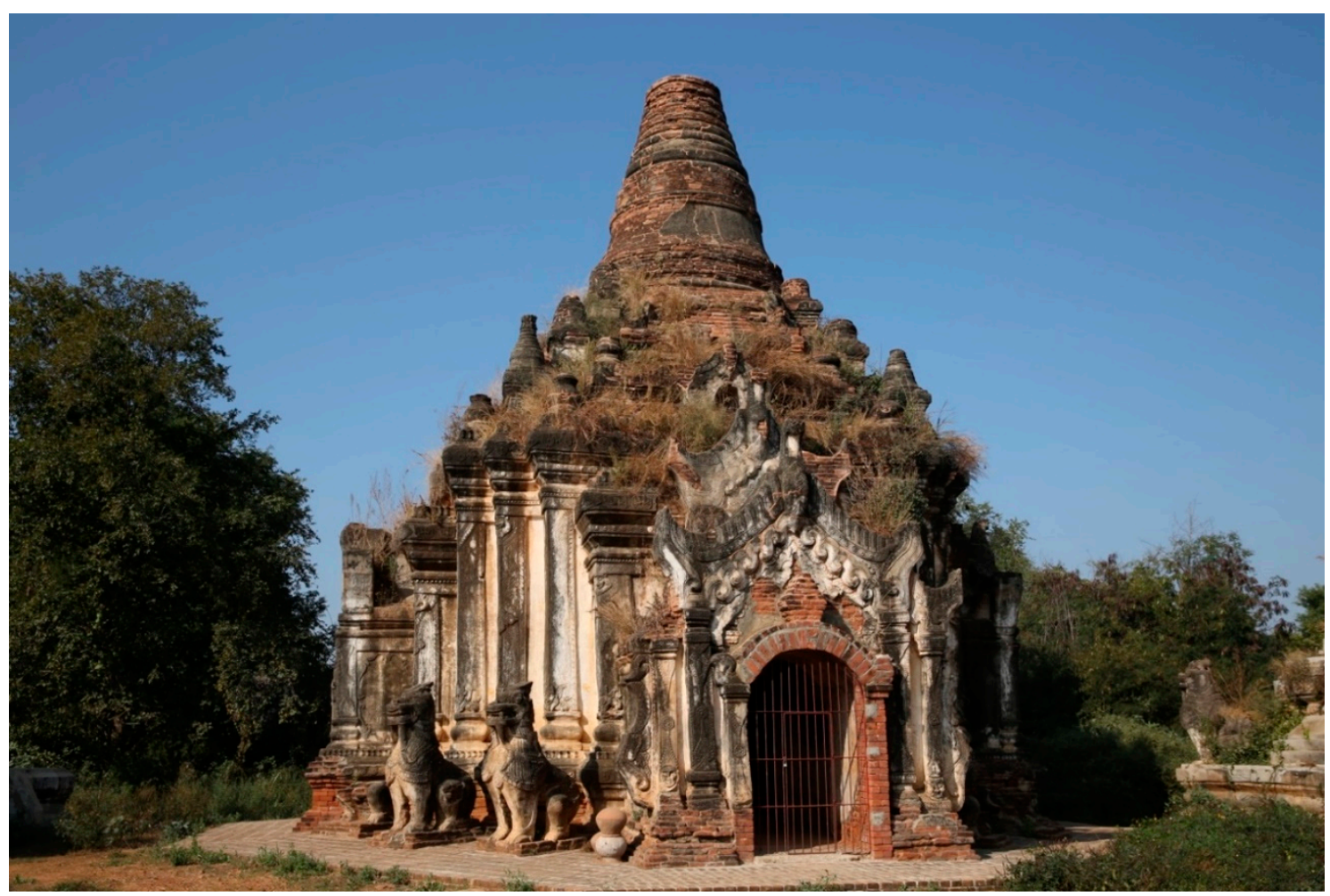

Figure 6. Anaint, 18th century.

Such stories had appeared in shifting garbs since the 11th century, when imagery reflected Northeast Indian origins. More important was what they serviced, an elaborate, sophisticated and influential conditioning mechanism on behalf of royal and communal needs. The mechanism was grounded in prevailing theories of psychology and physiology, meant to harness human emotions to create better royal subjects, referenced in inscriptions as "the good people, sappurisa". This Pali term first appeared in the Mon vernacular before the end of the 11th century and remained a staple of 
Burmese social thought for the next millennium. The conditioning stratagem sanctioned the practice of terrorizing people with frightening images, stories, and what Michel Foucault called spectacles of the gallows, because scaring them dramatically was believed to have positive results. ${ }^{6}$

The most famous hell denizen in the Burmese context was Devadatta, so bad the earth couldn't bear his weight, His evil was counterpart to Vessantara's virtues, which were likewise more than the earth could carry.

Devadatta's iniquities had the miscreant ultimately dropping into the ground en route to Avīci hell, there to keep company with other evil beings such as Ciñcā, who had falsely accused the Tathāgata of causing her (nonexistent) pregnancy. However, in the Dhammapada there was more. By the time Devadatta is in Avīci, his body had become gigantic to amplify the pain; he also wears a red-hot pan on his head and iron stakes pierce his body. For a Dhamma valorizing "loving kindness" or metta, this vindictiveness is telling, placing some beings beyond the pale. For these people, the more suffering inflicted upon them, the better, and letting people know this was a good thing. Nor were there concerns that hating the Buddha's problematic adversary was corrupting. Loving kindness had its limits, legitimating feelings very much its opposite. The psychology such attitudes articulated explains why hells and heavens were components in the kingdoms' socializing strategy and why stories about heavenly abodes that were the foil to stories about the nether worlds provided the equipoise the reigning psychology demanded. They were available as a counterbalance to what samvega wrought.

The settings where these not-easily-documentable practices and aspirations left identifiable traces in the Burmese context are the structures constructed to manifest their donors' Dhamma allegiance, social standing, and at least notional care for the society of which they were a part. Such care, in fact, extended to the universe as a whole, as we see how the merit formula sealing such good deeds was phrased. Embedded in such formulaic expressions was also the donors' explicit support for the conditioning process turning the people surrounding them into a coherently integrated society. The donors sponsored the visibility of the Buddha Gotama story, writ very large by recourse to visual narratives situated in parallel tiers or else within compositional grids, inscribed in the vernacular. The Buddha's story informed a tapestry on behalf of communal solidarity and socialization practices, serviced by visual means. For the purposes of this article, the evidence used covers the centuries between the rise and fall of the Pagan kingdom (9th to 13th century) and its dynastic successors, up until the late 18th century.

Visual narratives painted during these centuries reflect this society's ideational development and its struggles with the human condition. Tracing these contentions and the ideas embedded in visual narratives is a legitimate undertaking, because the Dhamma remained the main and unrivaled answer to life's big questions. This was not the only ideational resource humans drew upon to ease their plight, but it was the most highly articulated and thus has left the most historically reconstructable record. This was the case until the late premodern period, when rival explanations for the human condition, their bearers foreigners unlike any previous dynasties encountered, for the first time challenged its ideational monopoly (Figures 7 and 8).

$6 \quad$ (Foucault 2008). 


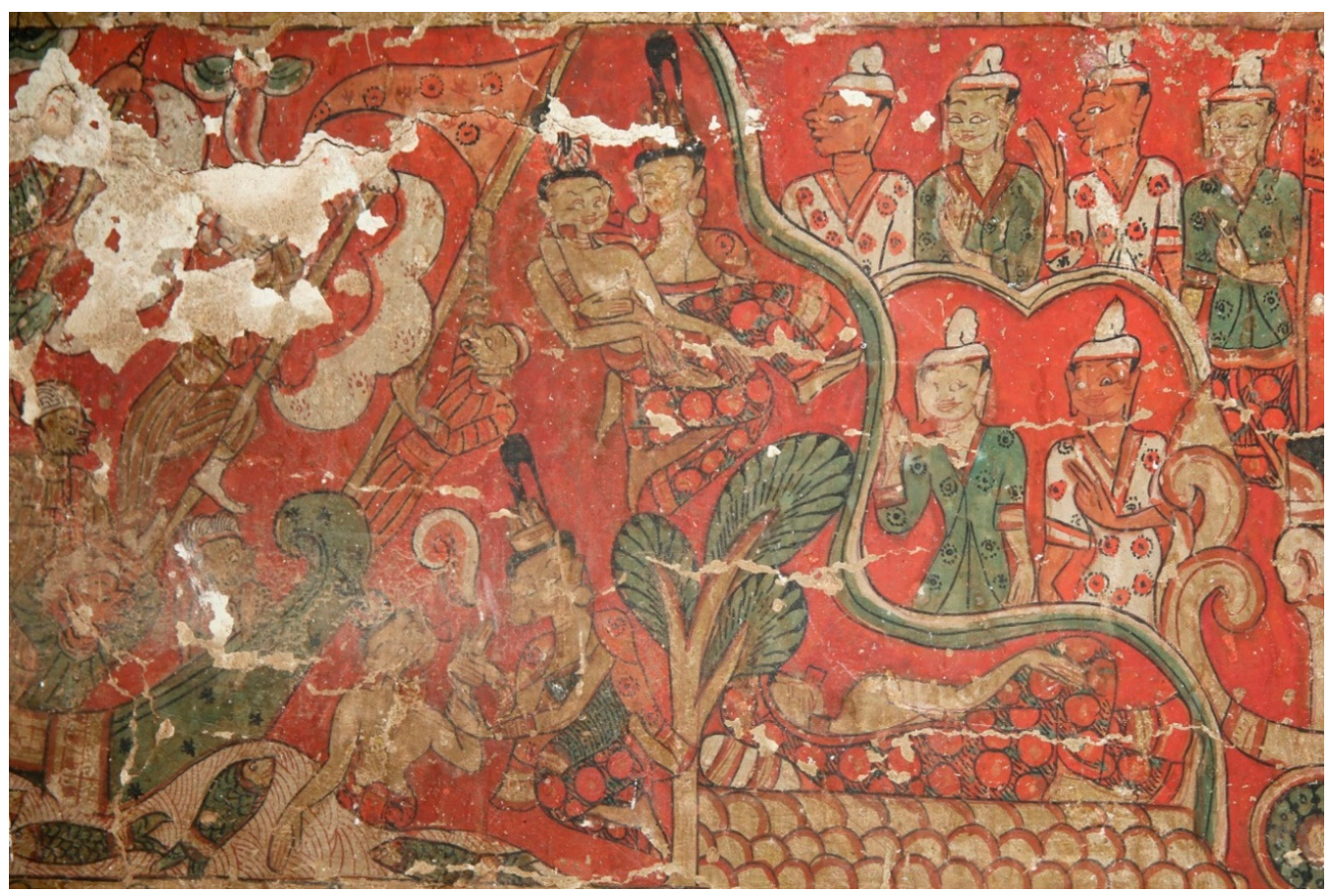

Figure 7. Anaint, 18th century. Foreigners as merchants in the Mahājanaka Jātaka, identifiable by their ugly facial features and attire.

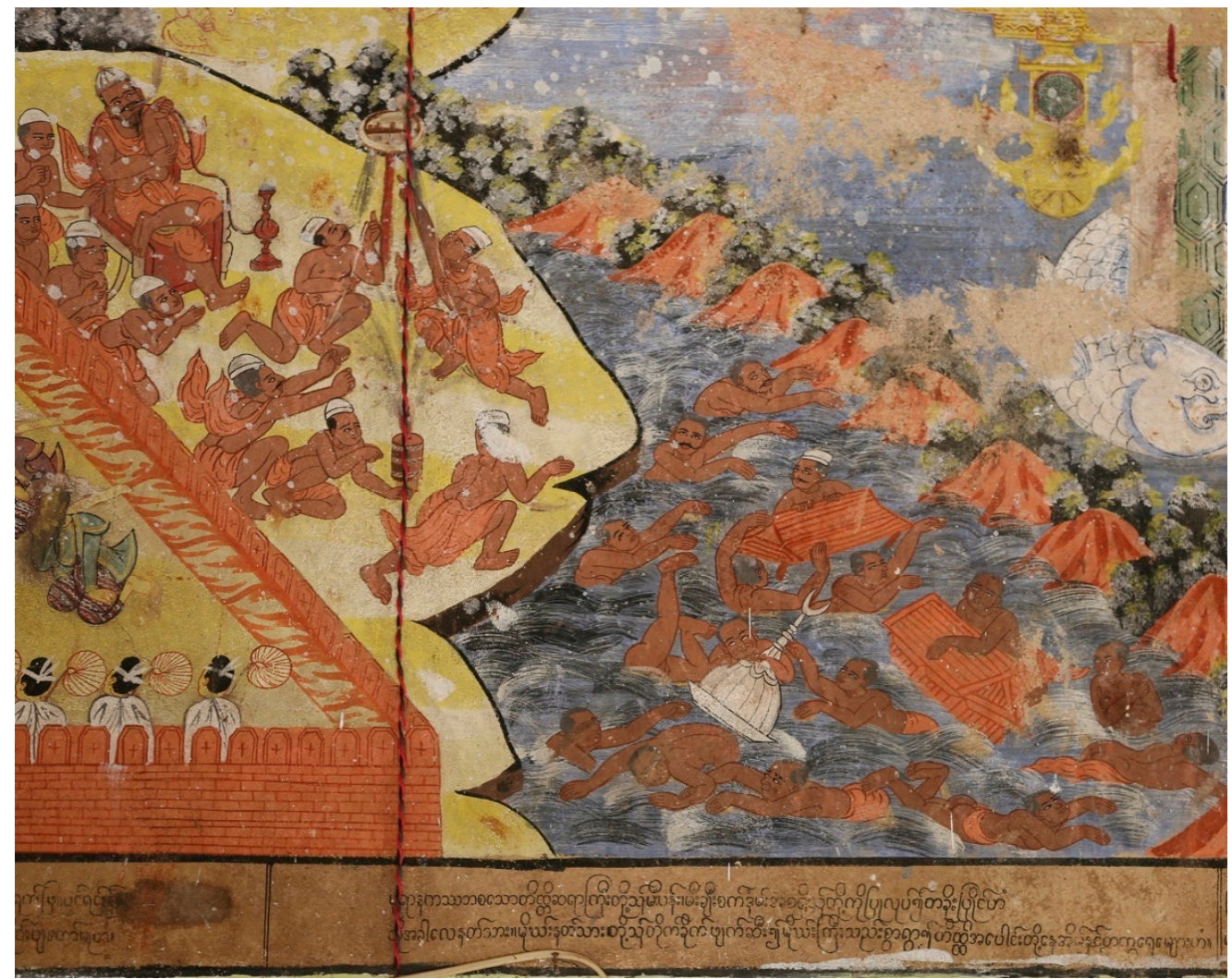

Figure 8. Pakokku, Shwetantit, 1917. Defeat of heretics identified here as Muslims, pointlessly clutching a mosque roof-recognizable by the crescent moon. They are drowning in the ocean surrounding Meru, hinted at by the giant fish encircling the mountain.

The popularity of hell and heavenly subjects in visual and ideational contexts fluctuated with the ebbs and flows of Burmese premodern history, refashioned by historical contingencies. Economists 
have noted, in other theocentrically informed settings, a relationship between interest in hells and economic incentives. Growing economic complexities and prosperity, that at the same time expose hitherto papered-over societal fissures, generate novel disarrays associated with more complex societies and advanced economic activities, encouraging interest in afterlives. Elsewhere, such fundamental historical changes promoted greater ideational investment in afterlife punishments. ${ }^{7}$ Whether this generalization also applies to non-theocentric civilizations, like Burma's, is one of the questions this article answers.

In Aśvaghoșa's Buddhacarita, The Life of the Buddha, during the second watch of the night of awakening, Siddhārtha sees all beings' births and death, including their sojourns in hell: "some are made to drink fiery molten iron ... some are devoured by horrid dogs, with iron teeth...if the evil doers could only see the fruit of their deeds ... they would ... vomit hot blood ... "8 This sliver is absent from the Pali Nidannakathā, one of the sources drawn upon in Pagan to master the complexities of the Buddha's partial biography. ${ }^{9}$ Concerns with hells and the heavens were, however, very much part of Pagan's public face early on, indicating the utility of the ideational construct, of which these two settings were a part. (Figures 9 and 10) Their relevance was broadly spread; meritorious animals also received their heavenly mansions' rewards, like the elephant, the horse, the monkey, and the ox, for example, in the 13th-century Kutha hpaya (845). As later donative inscriptions indicate, and as will be shown more extensively below, the threat of ending up in the netherworld was a living concept that donors feared.

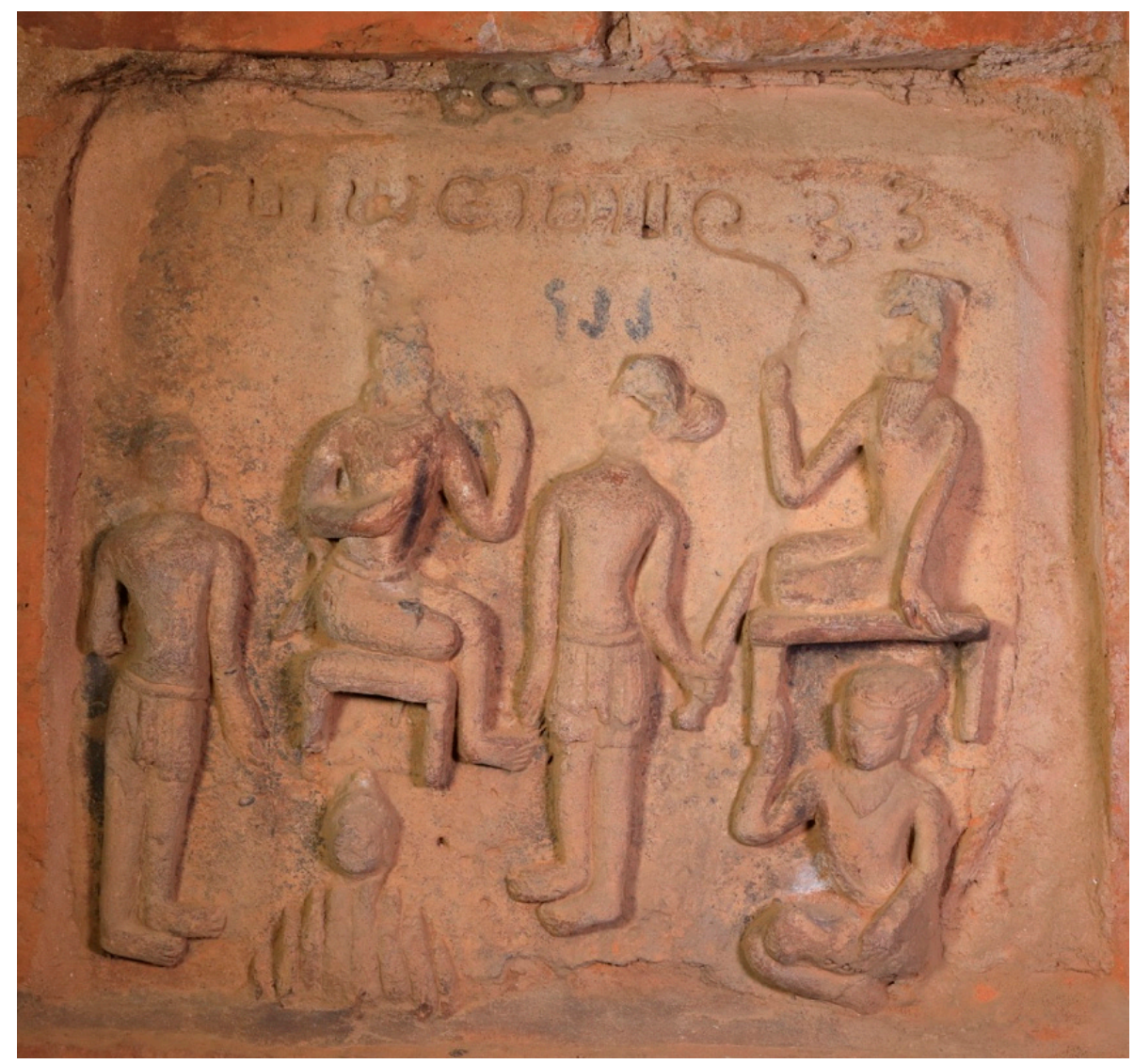

Figure 9. Pagan, Hpetleik Stupa, 11th Century. Jataka 422. Devadatta sinking into the earth, usually shown by a fire bursting from the underground, only the king's head remaining visible.

\footnotetext{
See (Barro and Cleary 2019).

(Olivelle 2008, pp. 405-9).

(Jayawickrama 2000, p. 99).
} 


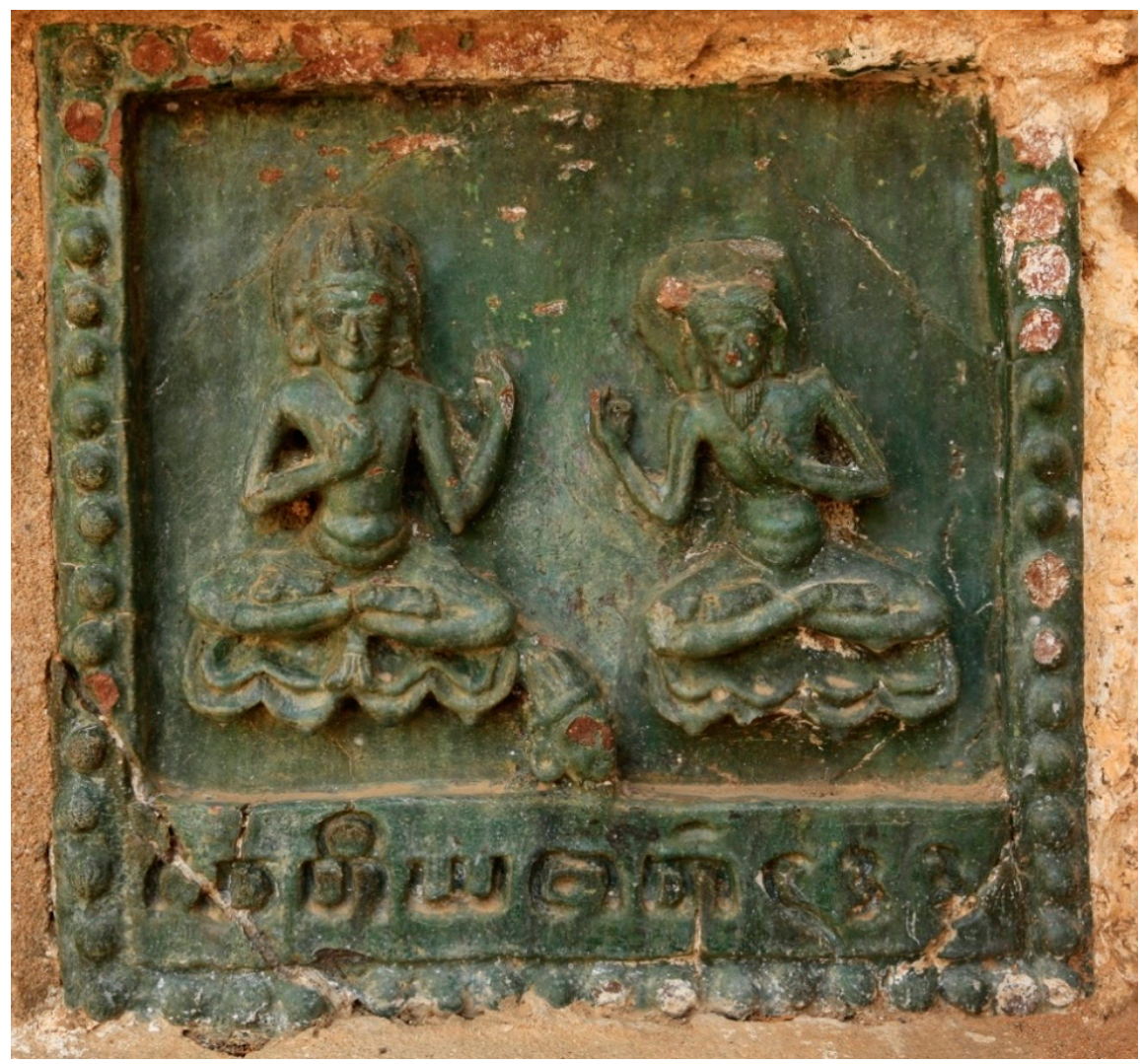

Figure 10. Pagan, Ananda Stupa, 11th Century, Jataka 422. Devadatta sinking into the earth, only the crowned head showing.

If images of hells and heavenly mansions socialized people into certain patterns of behavior, other sub-components of the Buddha tapestries likewise provided behavioral modification prompts. One example was the generosity of king Pasenadi, whose asadisadanna, incomparable donation, merited Pagan billboards, large images framing Gotama with subimages narrating the activities defining that gift's uniqueness, making the term part of the vernacular in later centuries. (Figure 11a,b).

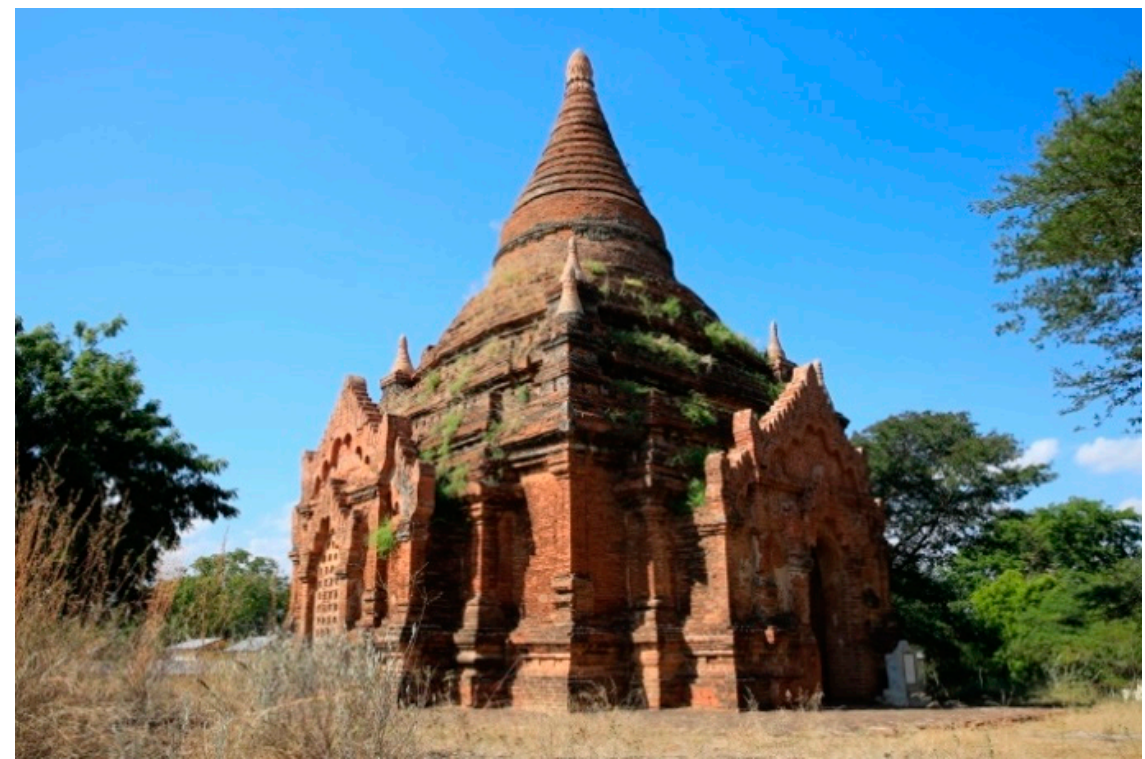

(a)

Figure 11. Cont. 


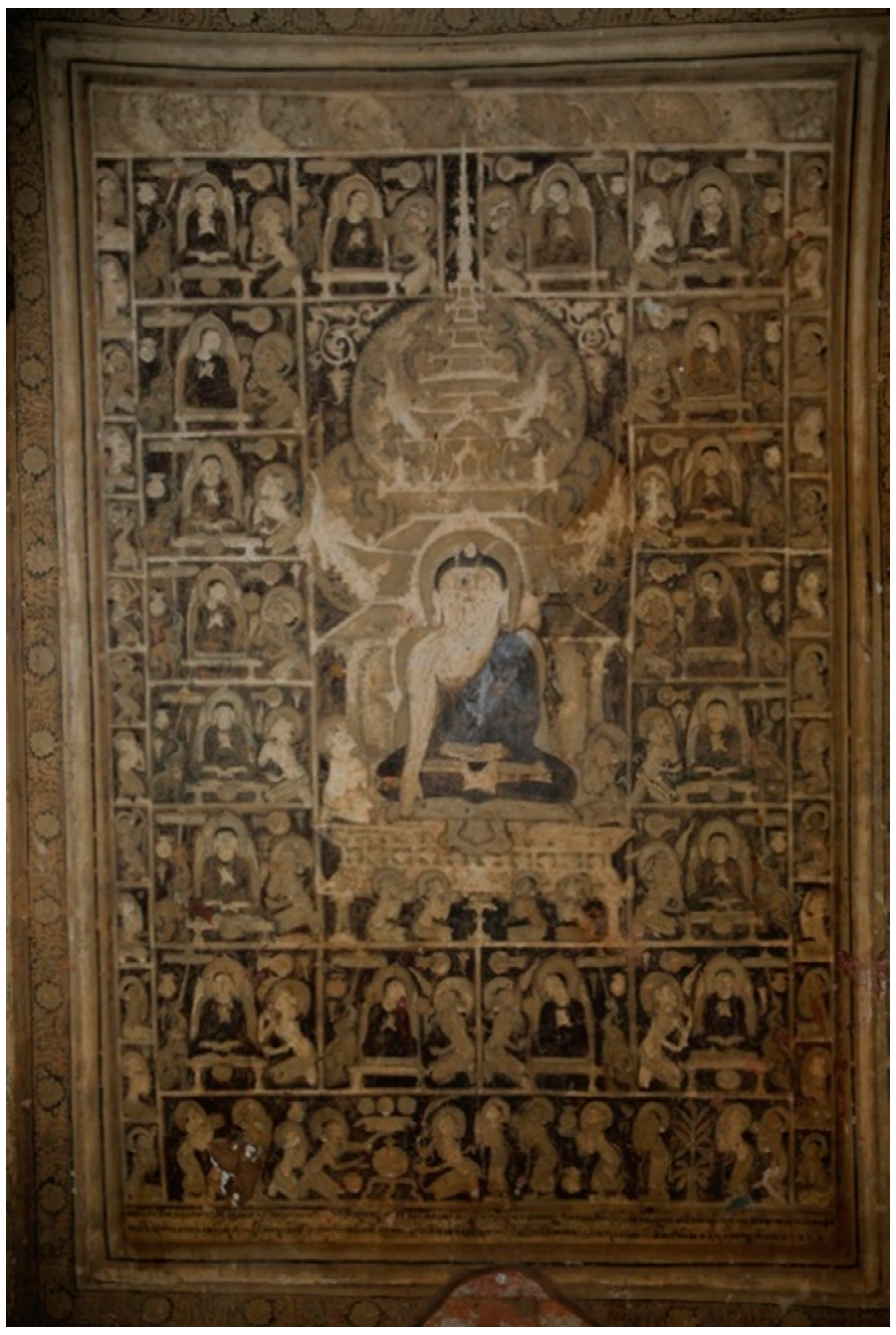

(b)

Figure 11. (a) Pagan, 13th century, endowment 585. (b) Pagan, 13th century, endowment 585. Big image illustrating king Pasenadi's Asadisadana, the incomparable donation.

This article argues that Burmese devotees' response to what they saw on the interior or external walls of endowments was taken into account by whoever inserted hell or heavenly images, and thus their stories, into the panoramas. If literary narratives transmitted orally enabled auditors to envision themselves in the place of another, images functioned likewise, implying anticipated engagement with what was seen. ${ }^{10}$ This we can elicit by examining how it was done, where such depictions appeared, what they transmitted, and why authorities encouraged their presence, thereby perhaps differently answering the question of what this massive financial and ideational investment was good for and why its components were perpetually in motion over the span of a millennium. Buddha bioramas foregrounded new sensibilities, and exposing these chameleon-like alterations illuminates the interplay between visual arts, their sources and message.

The interplay was assumed by scholarly investigators of Burmese history to be on behalf of "education." This explanation was inserted into the Burmese authorized narrative by the great pioneering scholars examining Burma's material culture. What they brought with them unraveled Myanmar's past in academic, but also largely European, terms. They unwittingly introduced into the context of Burmese scholarship their own classic early 20th century European training, in particular an

10 For broader implication of these issues, see (Hallisey and Hansen 1996, pp. 314-16). 
understanding of Western art history. The underlying assumption was that the latter's conclusions were universally valid, good for 6th-century Marseille, Renaissance Florence, as well as 12th-century Pagan. Much of the scholarship reconstructing the Burmese past came to harbor a Christianized vocabulary and conceptualization.

When applied to interpreting visual narratives in the context of Burmese devotional practices, the results were misleading. The interpretation's authority derived from the outcome of one of the more influential moments in European ideational history, when Pope Gregory I in the 6th century, delegitimized the Bishop of Marseille's iconoclasm and sanctioned recourse to visual arts. In doing so, he legitimized the arts not only for his own time but thereafter for the Europeanized world. Gregory I's letter on behalf of the visual arts' educational tasks made images and sculptures books for people unable to read. This was assumed to be notionally relevant to what Burmese royal and elite sponsors hoped to do on behalf of their wards, whose literacy rates, at least to begin with, were not different from that of their European counterparts. Visual arts were meant to compensate for people's inability to read. ${ }^{11}$ It was also assumed that visual prompts were part of a ratiocination process, privileging thinking over emotions, the mind informed by logic, as opposed to feelings.

If, as will be argued below, in the very different Burmese context, emotions determined visual narratives' tasks, pedagogical considerations, in the modern conventional meaning of the term, were likely to be secondary. Hence, using the term "education" to explain the determinative 11th-century visual turn in Pagan is problematic. Most scholars see no incongruities here, but we should, because the result yields a more plausible account of Pagan and subsequent dynasties' investment in visuality.

In the Burmese context, the use of Western paradigms meant not only the explanation that the visual presentations of the Buddha's teachings were meant to be "educational", but also the employment of terms like Buddhism, religion, prayers, temples, faith and Theravāda, for which, during Pagan times, and centuries beyond, there were no Pali, Burmese, or Mon equivalents. Such a vocabulary made no allowance for the essential otherness of the Burmese context and the high likelihood that, in this setting, different thought patterns prevailed, and what viewers anticipated their visual information to accomplish likely differed too. Even the late Steven Collins, who realized the significance of emotions like samvega and pasāda for the Southeast Asian world, credited encounters with images good for arousing "religious feelings or intentions". ${ }^{12}$ However, religion was not what was on display in Pagan and much later, because following the Dhamma in the early and premodern Burmese context was not a religion, in the sense of reflecting a similar ideational realm in which the Latin "religio" originated.

Equally problematic is the still-prevailing supposition that the Buddha's experience was somehow imitable, that what was being featured on endowment walls was the merit path to enlightenment that people were encouraged to follow. If there was one inference that the displays confirmed over all these centuries, it was that this was reserved over unimaginably long-time spans for an exceedingly select few. Awakening, and even Nirvāna (for the time being), given their mind-boggling complexities, were beyond most people's attainment and, as such, aspirations useless for purposes of daily life and organized society. The donative inscriptions' wish list did include Nirvāna, but when they become more loquacious, in later centuries, avoiding hell, guaranteeing either a heavenly mansion or a wonderful life on earth, and yearning for terrestrial wealth and prosperity as well as an easy rebirth were elaborated upon. As the following analysis indicates, exposure to a visual take on the Buddha's immensely complicated past occurred on behalf of more mundane ambitions.

Why this turn to visuality occurred around the middle of the 11th century remains unclear, but the question is worth asking even if no answer is forthcoming. Be that as it may, royal and later elite practitioners began to use their endowments to presence the Dhamma in the public domain, in ways unprecedented in this setting. None of the earlier surviving structures, associated with another group

11 On the larger issues involved, see (Duggan 1989).

12 See (Collins 1998, p. 593). 
influential in the region during the first millennium, now denominated the Pyu, featured anything remotely similar. Clearly, something happened to grant visuality a more central task than ever before. We may not know its causes, but the results made the Dhamma something to be looked at in the region for the next millennium.

\section{Visuality: Samvega, Pasāda, and Malleability}

However defined, visuality assumes seeing, a truism that nonetheless is key to how endowment decors were meant to be understood and what contemporaries believed happened, if only notionally, when people gazed at a structure's interior or a stupa's outer shell. (Figure 12).

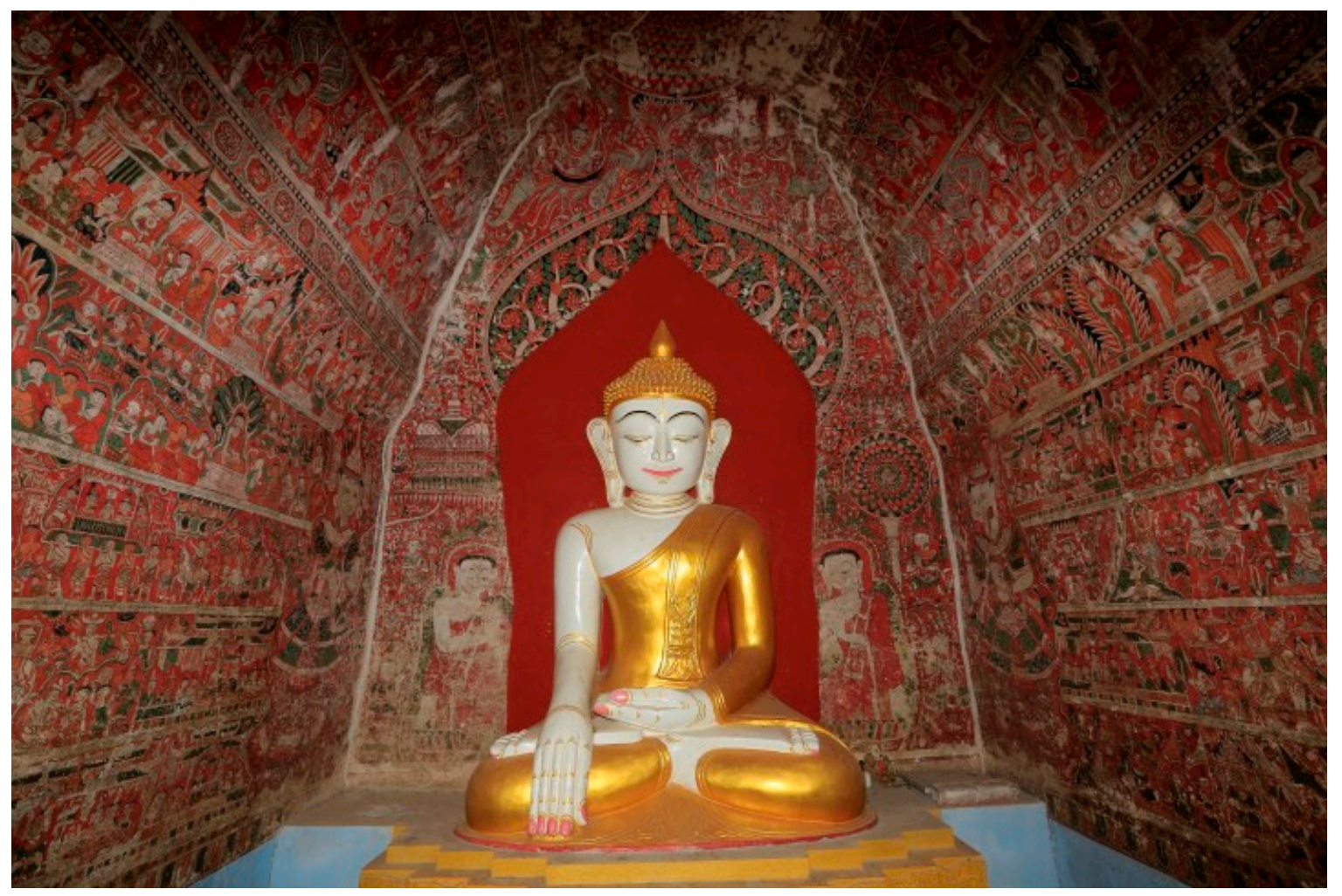

Figure 12. Salyingyi, 18th century, interior.

Unraveling what this meant necessitates unpacking what seeing presupposed according to written texts, the words of the Buddha or Buddhavaccana, used to articulate people's weltanschauung. The availability of such materials, canonical and post-canonical, is attested by inscriptions on endowment walls. How they were actually read, interpreted, and used needs to be teased out of the results, that is, when they became seeable.

What seeing likely meant for contemporaries was linked to the prevailing theories of human physiology and psychology that inter alia also argued that people were emotionally and ideationally pliable, and that this could be utilized. The Dhamma is a testament to this assumption, and the notion is central to texts that bridged the gap between the Buddhavacana and those meant to be governed by it.

In that context, what scholars have called ethically valorized emotions, because they promoted right conduct, were illustrated via stories, sermons, and images as well as through rituals and devotional practices that were grounded in how humans were perceived. ${ }^{13}$ That perception, elaborated below,

13 See (Mrozik 2012, pp. 261-88). 
also posited a connection between the immediate and future outcomes of deeds. Present and future punishments intertwined, becoming a form of social control. The relationship was a staple in the narratives where the amplification of what hells meant frequently straddled both time frames. In the Valāhassa jātaka (no. 196), transgressors became goblins' supper before going to hell. Kokāliya, one of Devadatta's followers, was covered with ulcers discharging pus and blood, resembling a poisoned fish, before the more horrific torments in the netherworld (Sutta nipāta, Kokāliya Sutta, 3.10)

Dread-evoking or hope-inducing images materialized because external prompts like visual narratives generated emotional responses that internalized their import. These images were meant to inform what in contemporary terms is defined as moral agency and the imagination necessary for ethical action, since they facilitated understanding of the consequences of one's choices. ${ }^{14}$

Imagination was linked to images because assimilating what one saw required it, though in the context of the Pali informed world, imagination had a mixed reputation, deemed useful, but also problematic. Buddhaghosa, the great theoretician of the Pali path, regarded images as an inferior form of information transmittal. This was why "guarding" the doors of perception, including seeing, was a desideratum for monks, since unguarded sense faculties facilitated misconduct, which, as another important doctrinal text, the Itivuttaka, warned, led to hell. ${ }^{15}$ (Figure 13)

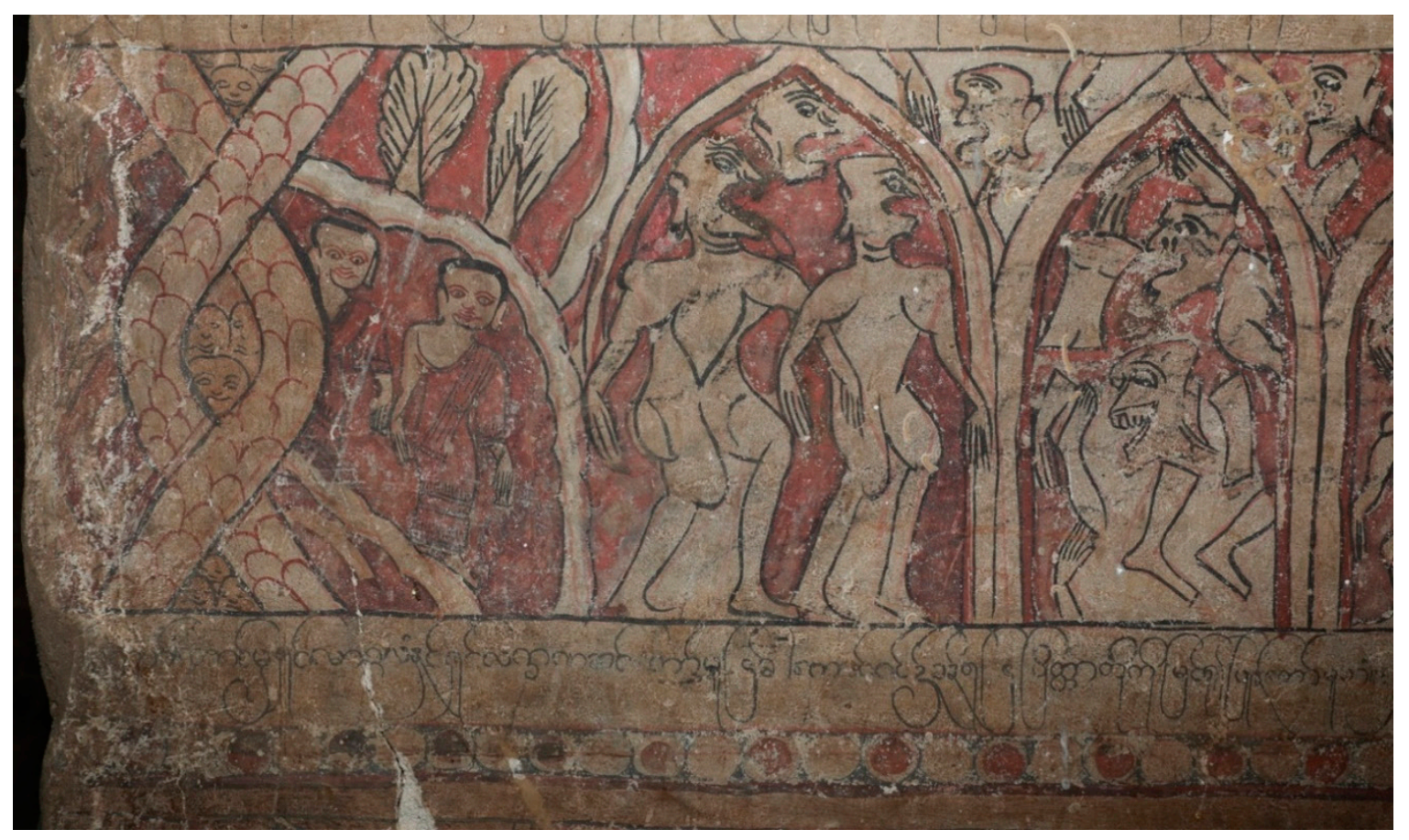

Figure 13. Pakhangyi, Endowment 227, late 18th century. Shin Mogalan and Shin Lakshana descend from the mountain. They see in the sky that there are ghosts and then they smile.

However, as the concept of samvega proved, visual narratives had their uses, especially when grounded in reliable testimony. Canonical and extracanonical texts carried reports from distant shores, as in the story of King Nimi (Nimi Jātaka, 541), or accounts of the travels of wonder-working monks like Moggalāna and Shin Malae, the Burmese equivalent of the better known Thai Phra Malai. Such tales were translated into visual formats. They attested to the existence of realms where either punishments or rewards for earthly deeds materialized. The links were made explicit; thus, for example, in the 
Sarabhanga Jātaka (522) in the story of the present, Moggallāna recounted his adventures in the lower and upper regions, while, in the story of the past, the bodhisatta outlined what brought beings to hell.

There is no indication that, at least on the popular level, anyone thought these cosmic realms were unreal, (Figure 14), nor does anyone seem to have been excited by the problematics of what was being roasted in hell's pots or who was living the high life in a Tãvatimsa palace, given the disintegration of all constituents at death. ${ }^{16}$

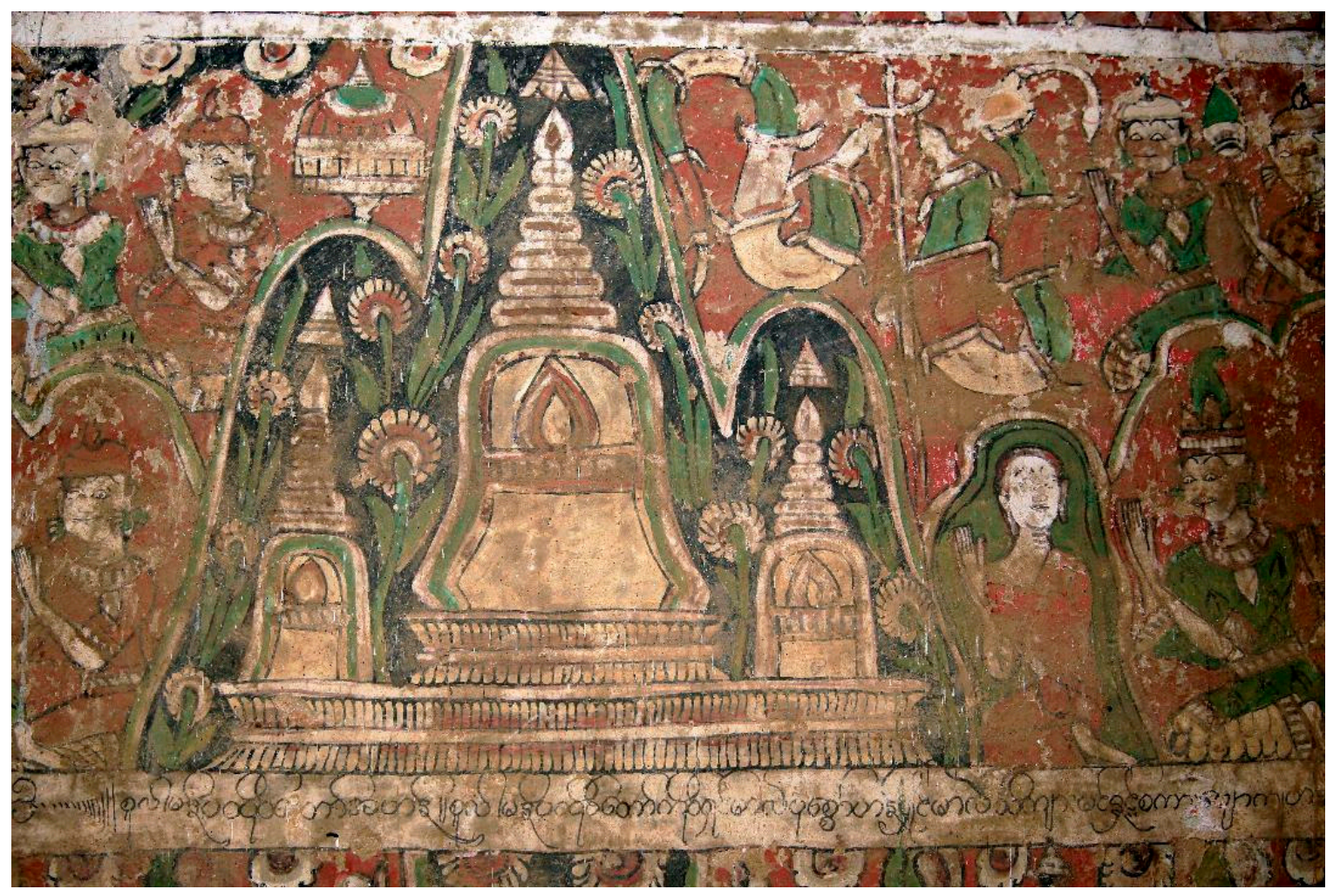

Figure 14. Pakhan nge, Manawyama, 18th century. Shin Malae sweeping Tavatimsa. The gods and Indra make offerings to the Sulamani (Culamani) Hpaya and converse with Shin Malae.

Nāgasena's tutorial for king Milinda considerably simplified the complex issue of how the eye responded to external images and how information was thereby registered physically and ideationally, first by the eye and then by the mind. In his streamlined explication, eye contact (among other sense contacts) evoked feelings, arousing awareness, and eventually reflection and intention. ${ }^{17}$

Buddhaghosa was more precise, elaborating on the relationship between what he called eye consciousness, and how the truly informed were able to see through the charade that is the seemingly perceived reality. He takes as an example the story of Mahā Tissa's encounter with a provocatively dressed young woman. Mahā Tissa became an arahat, because what he truly saw in front of him was a set of repulsive bones, unlike the woman's besotted husband who was unable to distinguish between the seemingly and truly real. Buddhaghosa outlined for monks the safeguards against seeing's deleterious effect when activating eye consciousness, crediting his predecessors' (the ancients or porāna [s]) with unraveling what happened, given that the eye by itself saw nothing, since it was merely an instrument in partnership with something else: mind consciousness. Both needed to be

16 See for a general discussion of the problematics of hell, the pioneering article (Braarvig 2009).

17 (Davids 1890) Rhys Davids, translated. 1890. I:89. 
restrained, ideally by virtue, to avoid misleading impressions. The latter were misleading because they simulated a reality that was not there to begin with. ${ }^{18}$

The most elaborate analysis of what seeing involved posited the existence of seven kinds of eyes, of which the human eye was the most primitive, a tripartite explication thereupon discussing the 13 constituent parts of the physical eye, further segmented into 40 sub-pieces. ${ }^{19}$ However, for more mundane purposes, like structures' visual content, seeing's actual functionality was replaced by the more ordinary uses of exposure to images whose transformational power inhered in their being seen as such, not for the unreality they truly represented. This explains why Nāgasena's elaboration to Milinda resembled a tutorial for dummies, since what Nāgasena stressed was how emotions were elicited by appropriate visual stimuli. This link to emotions was vital, as will be shown below.

Sight, for all its shortcomings, was a crucial capacity, difficult to bypass, and important for two emotions that, among others, informed humans' response to the outside world. These are samvega and pasāda. The two were among the emotions that mediated the processing of what was seen and visual stimuli's utility. No Burmese equivalent from this period survives, but the reaction to hell images experienced by the great 12 th century Japanese monk-poet Saigyo, at around the same time, indicates how, in a setting where similar ideational constructs prevailed, people reacted to what they saw and how they interpreted the experience. For Saigyo, images of lower realms led to despair about his incapacity to avoid a similar fate. ${ }^{20}$

The poet, confronting such images, reacted in a way his Burmese counterparts would have understood. In both settings, samvega was an emotion fraught with terror and trepidation, generated by an ideational assault on the very core of one's being. The resulting turmoil was to be alleviated by pasāda, a form of reassurance. These were two pillars, among others, of a conditioning mechanism on behalf of people's present and future wellbeing.

The conditioning strategies were grounded in the assumption that samvega and pasāda were human emotions whose arousal, through seeing images of hells or heavenly mansions, for instance, were useful. (Figure 15) Today, the method would partially be called aversion therapy. Similar, is the case of monks conditioned to conquer lust by exposure to its provocations, since engaging with temptations overcame their effect. For popular purposes, a carrot was also needed, in the form of stories about lives in the higher realms. The conditioning mechanism, and emotions conducive to its functionality, molded the wished-for "good people"-the kings' ideal subjects, candidates for stupendously happy afterlives. The notion that human nature was pliable was central to this weltanschauung, encouraging recourse to external prompts like visual narratives to evoke ameliorative responses. The Tathāgata used harsh words (an equivalent of horrific images) "to soften beings and make them pliable", and images potentially did likewise. ${ }^{21}$

Pliability facilitated molding moral agency and the imagination necessary for ethical action. Understanding the consequences of one's choices relied in part on a shock and awe strategy. "Seeing hells' fearfulness", said the Ainguttara Nikāya and numerous other texts, hopefully made people "shun wickedness". ${ }^{22}$ This was a desideratum not only because wickedness was punishable with terrible tortures for an unimaginably long time, but also because it fostered societal disarray and thus hindered the king's subjects from living the good life.

The most famous illustrations of what images or visual cues could do and how samvega and pasāda operated were Siddhārtha's encounters with the Four Omens, with which I began this essay. The parable featured also in narratives where the Omens appeared as metaphors for life's realia, most famously in the Majjhima Nikaya's (Middle Length Sayings) Ariyapariyesana sutta that elaborated on

\footnotetext{
(Nanamoli 1999). Buddhaghosa, The Path of Purification, Visuddhimagga, I:53, 55, 57.

See excellent discussion (Anderson 170ff.) (Masefield 2000, p. 52).

See (Sorensen 2012).

(Bodhi 1993, p. 104).

(Woodward and Hare 2008, 3:156).
} 
the broader meaning enveloped in what-in other contexts-were the Four Omens. ${ }^{23}$ The Omens were illusory; gods disguised themselves to reveal life's facts to the pampered prince, presenting what was not physically there, but nonetheless crucial for the response exposure generated. The ruse worked, indicating how what was seen could have profound effects-altering the prince's grasp of reality, generating an emotional upheaval that, in turn, had stupendous consequences-attesting thereby to the utility of manipulated appearances. The prince in the Yuvañjaya Jātaka (no. 460) mastered life's facts by observing the evanescence of dew, experiencing a samvega moment much like prince Siddhārtha's, as befitted his being the bodhisatta in a previous life (Figure 16)

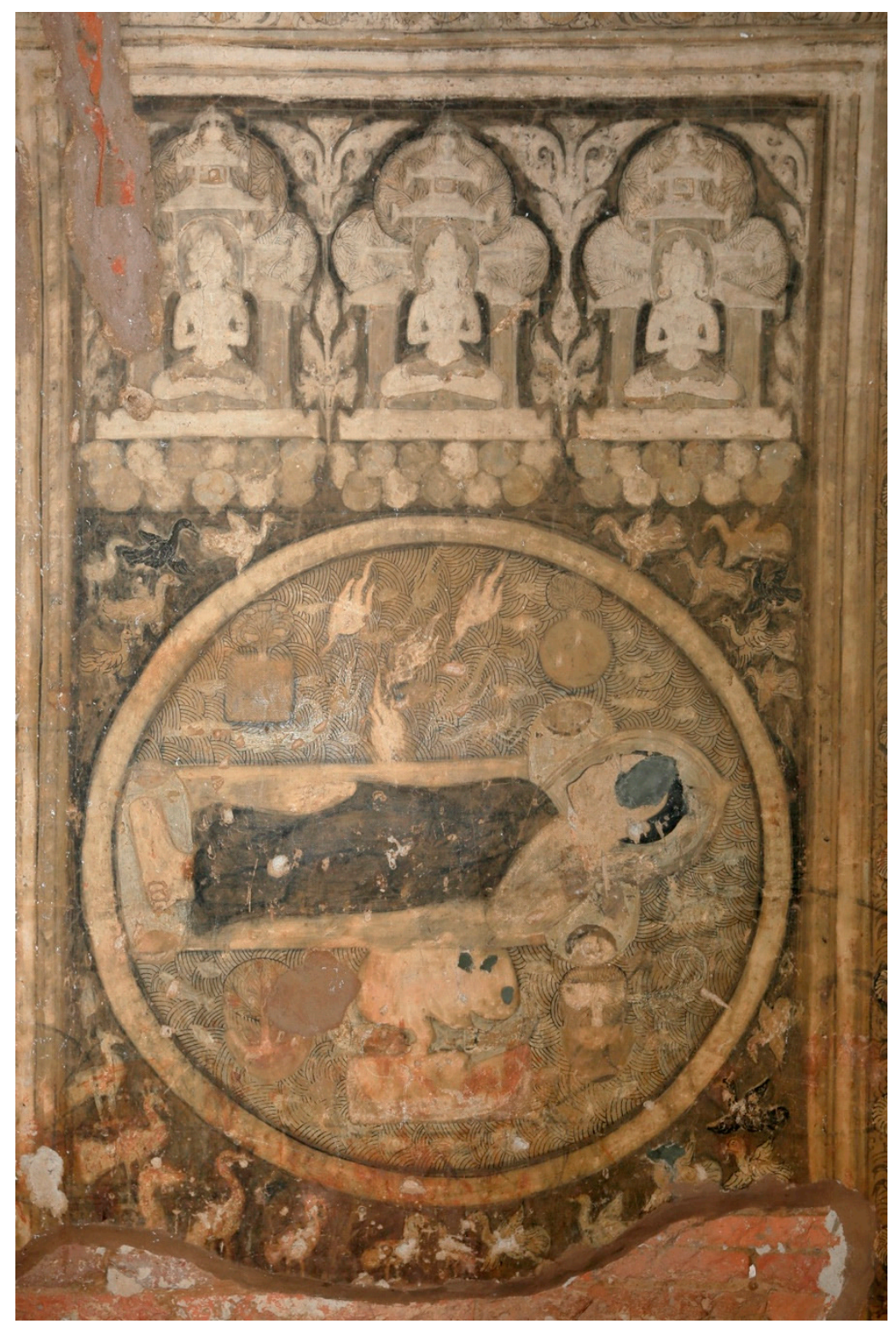

Figure 15. Pagan, 13th Century, endowment 585. The bodhisatta's dreams on the Night of Awakening, linked to three heavenly mansions providing corroboration for the dreams' interpretation.

23 (Nanamoli and Bodhi 1995, pp. 253-68). 


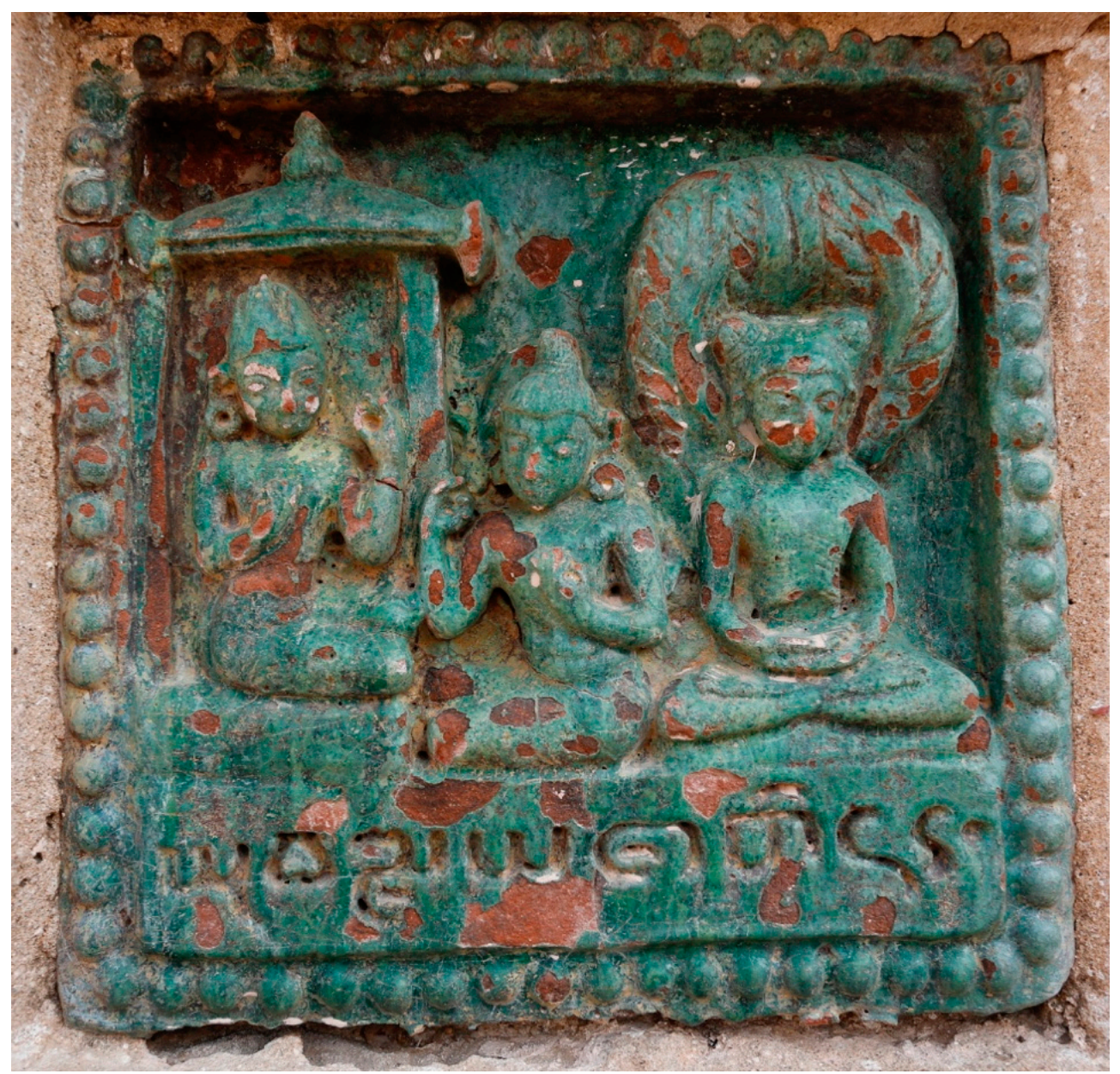

Figure 16. Pagan, Ananda, 11th century. Yuvanjaya, Jataka 460. A monoscenic interpretation, on a glazed plaque, encapsulating a story linking sighting a natural phenomenon-the sun burning away the dew-and grasping thereby life's meaning.

The Anguttara Nikāya insists that the Four Omens are part of everyone's life, but are ignored, and the result is hell. ${ }^{24}$ This is echoed by the Devadūta sutta of the Majjhima Nikāya, where the thickheaded transgressor assumes that the Omens don't apply to him. The Devadūta sutta is one of the texts whose content appeared listed seriatim by title, on endowment walls, a form of footnoting 11th-13th century style. When asked by king Yama whether he stumbled upon "divine messenger(s)" — counterparts of the ones that set prince Siddhārtha on the road to Buddhahood-a miscreant admitted to having encountered them but, misinterpreting their message, failed to draw the right conclusion, namely that what he witnessed applied to him as well and was also a clue to present and future punishments. The sutta also mentioned the "good people", sappurisa, who, unlike this hell inhabitant, heeded omens and dwelled in bliss. ${ }^{25}$

The emotional upheaval samvega evoked was said to resemble what birds sensed at the sight of a falcon, what a monk experienced when forgetting the Buddha, and what the bodhisatta felt when realizing that, left unattended, people floundered like fish in dried up ponds. Agitating him with dismay, anxiety and a sense of urgency, this was what Yasa sensed in the Theraga $\bar{a} t h \bar{a}$ commentary to verse 117, when he woke up surrounded by disgusting looking sleeping women, echoing a subchapter in prince Siddhārtha's biography. Sampvega generates Yasa's receptivity to the Buddha's teaching,

24 (Woodward and Hare 2008, I: 123ff).

25 (Nanamoli and Bodhi 1995, pp. 1029-38). 
making him an instant arahat because, the Buddha explained, his karma caused him to wake up at the right time to be primed for the samvega moment. Buddhaghosa described people's reaction to the news, broadcast to the universe by the loka byuha deities, that the world was about to end, how all "human beings and earth deities [were filled] with samvega. They become kind to each other and make merit with loving kindness ... " It was also what Sakka, his hair standing on end, felt when witnessing Moggallāna's extraordinary powers. Or else it was the emotion that enabled a compassionate tree spirit to restore wayward monks to their senses, including Ānanda, Moggallāna, and Sariputra, who embarked on the right path as a result of samvega experiences, while a paccekabuddha was said to attain paccekabodhi, a form of awakening, having been disturbed by a samvega nimittam, a samvega sign. Luxuriously living devas' samvega moment, when they realized their time was up, meant being "struck with fear, filled with terror, like beasts who hear the lion's roar". ${ }^{26}$

Samvega was also what people were to experience, according to the Buddha's instructions in the Mahāparinibbāna sutta, when in the presence of four sites associated with his life, suggesting the underdetermined term's other connotations and why later generations were able to adjust it to their changing perceptions of the human. The different reading here indicated that an emotional shock need not have been something with only negative connotations-on the contrary, it could evoke awe and overwhelming respect, hinting at a different slant. A 19th century Burmese commentator compiled a lengthy text, grouping stories featuring samvega in conjunction with other inborn qualities attesting to the ideational construct's enduring relevance. ${ }^{27}$

Though, as Trent Walker pointed out, samvega was rarely paired with pasāda in the core Pali texts, in the later commentarial literature and in the most famous instantiation of the shock and awe stratagem, in Siddhārtha's encounter with the Four Omens, pasāda was an inseparable part of the equation. ${ }^{28}$ It meant a clarity-inducing serenity, resolving what samvvega wrought. Pasāda's presence was a psychological necessity, ensuring that in the world as constituted there was an answer to the despair and fear beings like Siddhārtha experienced when realizing life's true nature. Pasāda was an antidote, relieving anxiety and uncertainty. This is seen in numerous stories; it was the case when king Mahājanaka in the famous Mahäjanaka Jātaka, 539, pondered the destiny of two mango trees: a fruitful one despoiled of its fruits, and a barren one that remained intact. He first experienced samvega and realized that kingship was just like a tree with rich fruits; everyone wants a piece of it. Then, he knew too that the life of a renunciant is like the barren tree, left in peace. This was his moment of pasāda, of resolution.

Pasāda was the emotion that prince Siddhārtha experienced when encountering the recluse in the context of the Four Omens, featured in gandhakuti(s), during the Pagan period and relic or Uddesika Cetiya(s) later on, the ideational distance between "perfumed chamber" and "memorials", indicating the Dhamma's chameleon-like nature. Those who understood the Fourth Omen, and what Siddhārtha felt in its presence, generated the sense of being contented at heart, an inner calm pacifying samvega's emotional storm.

The first scholar to realize samvega's significance in the context of Asian art was Ananda Coomaraswamy. In a pioneering 1943 article entitled "Samvega, an Aesthetic Shock", Coomaraswamy suggested that visuality meant to impact viewers in ways beyond cognition. In his interpretation, the sense of dread and agitation samvega instantiated resembled a person's encounter with a corpse, reminding us that the so-called eight emotional prompts (Coomaraswamy called them "themes") (attha samvegavatthūni)—that is birth, old age, sickness, death and suffering arising in four ways)—generated a state of distress important for Asian artistic creativities. Coomaraswamy did not elaborate how the

26 (Jayawickrama 2000, pp. 78-80; Nanamoli 1999, XIII: 34, 35; Nanamoli and Bodhi 1995, pp. 186, 344; Bodhi 2000, p. 294ff; Coomaraswamy 1943). (Sourced from Connected Discourses on the Aggregates. 78. The Lion. (This is Bodhi 2000). Anguttara Nikaya, the Book of Fours, The Lion—this is Bodhi 2012). See also (Nyanaponika and Hecker 1997).

27 (Walshe and Thera 1995, pp. 265-66; Jagarabhivamsa 1986).

28 See (Walker 2018, pp. 271-325). 
Dhamma's interpreters contextualized the nature of this particular emotional response in broader theories of human functionality, nor was he interested in how interpreters of Pali texts read revered materials in light of theories of seeing and human physiology, relevant to the transformations of the self. However, he sensed that defining Asian art in Western terms distorted native creativities. Coomaraswamy ultimately connected samvega with such abstractions as a "convincing statement of truth", linked to "intellectual art", as well as assumptions regarding aesthetics that, this article argues, are inapplicable to the Pagan setting. More recently, Trent Walker linked samvega to Indian notions of rasa, while acknowledging the Pali canon's slight interest in aesthetics. In the Burmese context, this article suggests, samvega played a different role, informed by psychological and physiological assumptions rather than rasa theories. ${ }^{29}$

Hell images and the stories about kammatic accounts behind them, were, in effect, samvega prompts. Images of ferocious birds pecking at corpses or scavenging dogs feasting on bodies were components in a sophisticated conditioning stratagem that exploited viewers or witnesses' emotions, grounded in a prevailing understanding of human psychology, to jump start a transformational process. It was not enough to show the wicked Ciñcā sinking into the ground; en route, black birds were shown attacking her body, in a later interpretation that was not part of the textual source but meant to augment her punishment. (Figure 17)

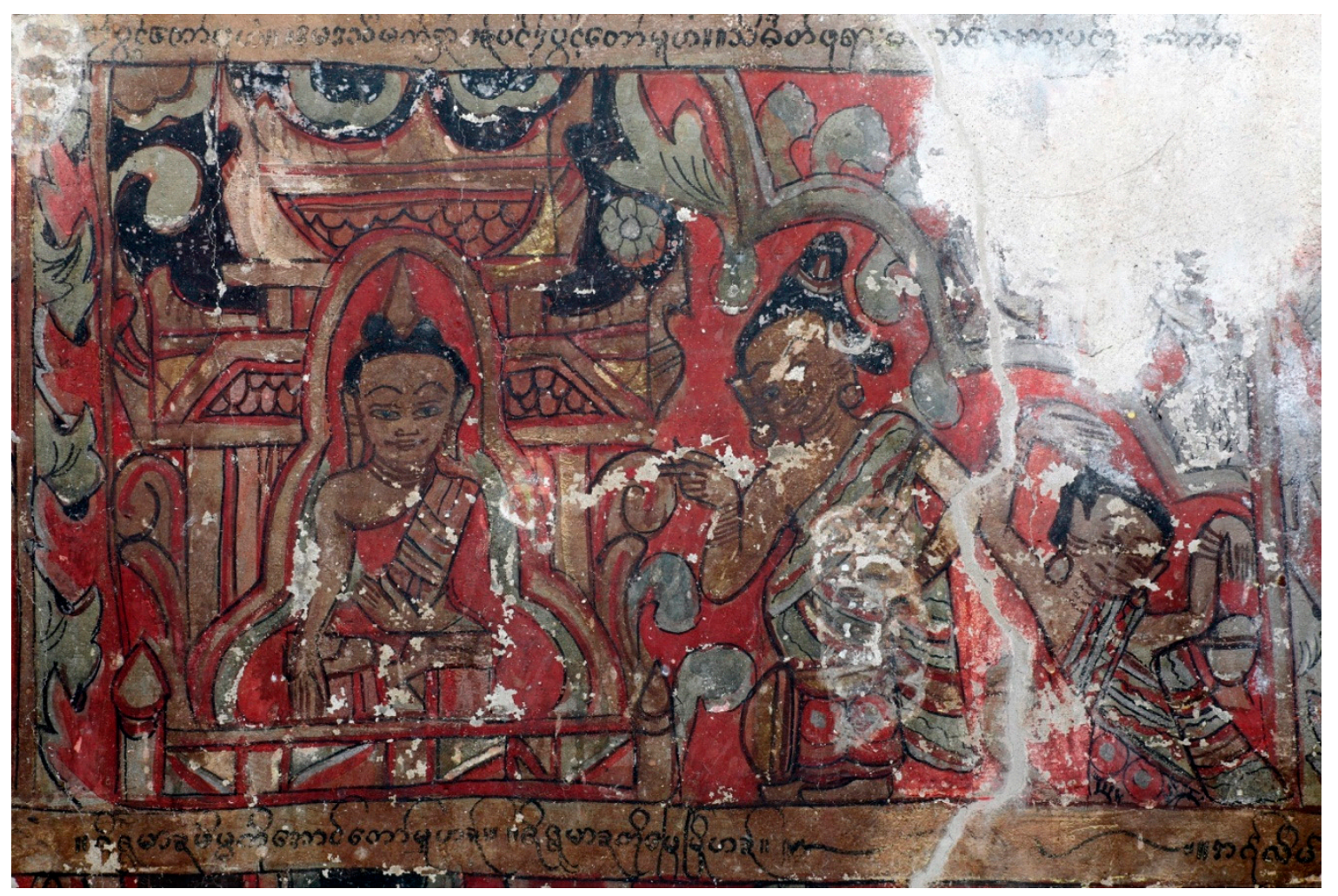

Figure 17. Salyingyi, 18th century. Punishment of Cinca, the bowl she used to fake her pregnancy on the ground, showing her next sinking into the ground.

A Burmese commentator describing a devotee's encounter with a disgusting looking peta devouring his own flesh, made the very sight salutary, even before what the peta had done to merit this behavior was clarified. The horror evoked by witnessing self-cannibalism was the samvega trigger. ${ }^{30}$

29 (Coomaraswamy 1943; Walker 2018; Heim 2003).

30 Mingun Sayadaw 6: 180ff. He links it also to the Udana Atthakatha and the Saratthadipani Tika. 
The psychology on hand assumed a human capacity for self-transformation, whereby using inborn skills activated emotional responses, sometimes with the help of what was called heedfulness (appamāda); practicing, for example, Buddha-recommended recollections, brought into play emotions molding appropriate intentions. ${ }^{31}$ How this worked can be unpacked through Buddhaghosa's influential scheme of psychological and ideational manipulation, meant to transform ordinary men into monks. Early on, the Visudhimagga tells the story of the monk Dhammadinna showing his audience the facts of life; when turning his fan down, the audience sees the road to Avīci. When Dhammadinna turns his fan up, they see the Brahma world, rousing "fear of hell and longing for the bliss of heaven". Nga ye images, the Burmese vernacular for the Pali niraya were thus the sticks, and vimānas the carrots, fear and hope in tandem. ${ }^{32}$

\section{The Uses of Fear}

Using hell images exploited fear, turning it into a key component of the conditioning process, informing the meaning of samvega, and necessitating what pasāda offered, because evoking dread was good, but it also needed an antidote. (Figure 18) As Nāgārjuna put it in his Suhrllkeha, a friendly letter to the king, " ... fear will arise through seeing pictures of hell, reading, remembering or hearing about them" and useful, since other people's misery had salutary effects, which was why Nāgarjuna, Bhāviveka, and their Pali counterparts piled it on, describing, among many other horrors, sliced bodies cooked like a mass of rice in great pots. ${ }^{33}$ (Figure 19)

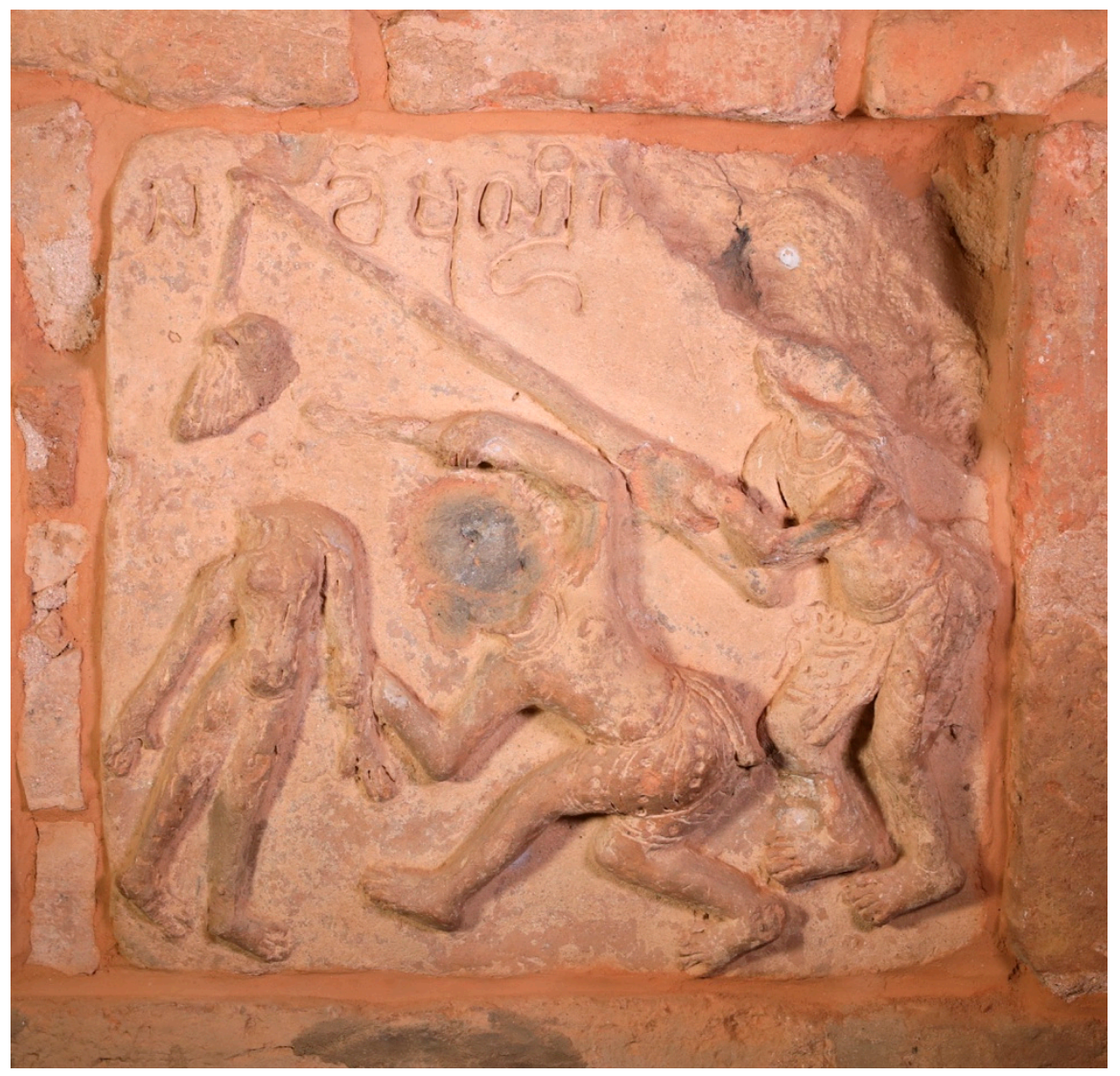

Figure 18. Pagan, Hpetleik stupa, 11th century. Sankhamundika Hell.

31 (Heim 2003, p. 533).

32 (Nanamoli 1999) 12:80. I thank Professor Phyllis Granoff for alerting me to this citation, private communication, June 2019. For broader issues regarding the use of emotions, see (Harre 1998; MacIntyre 2002; Solomon 1995).

33 (Gardiner 2012, p. 53119). 


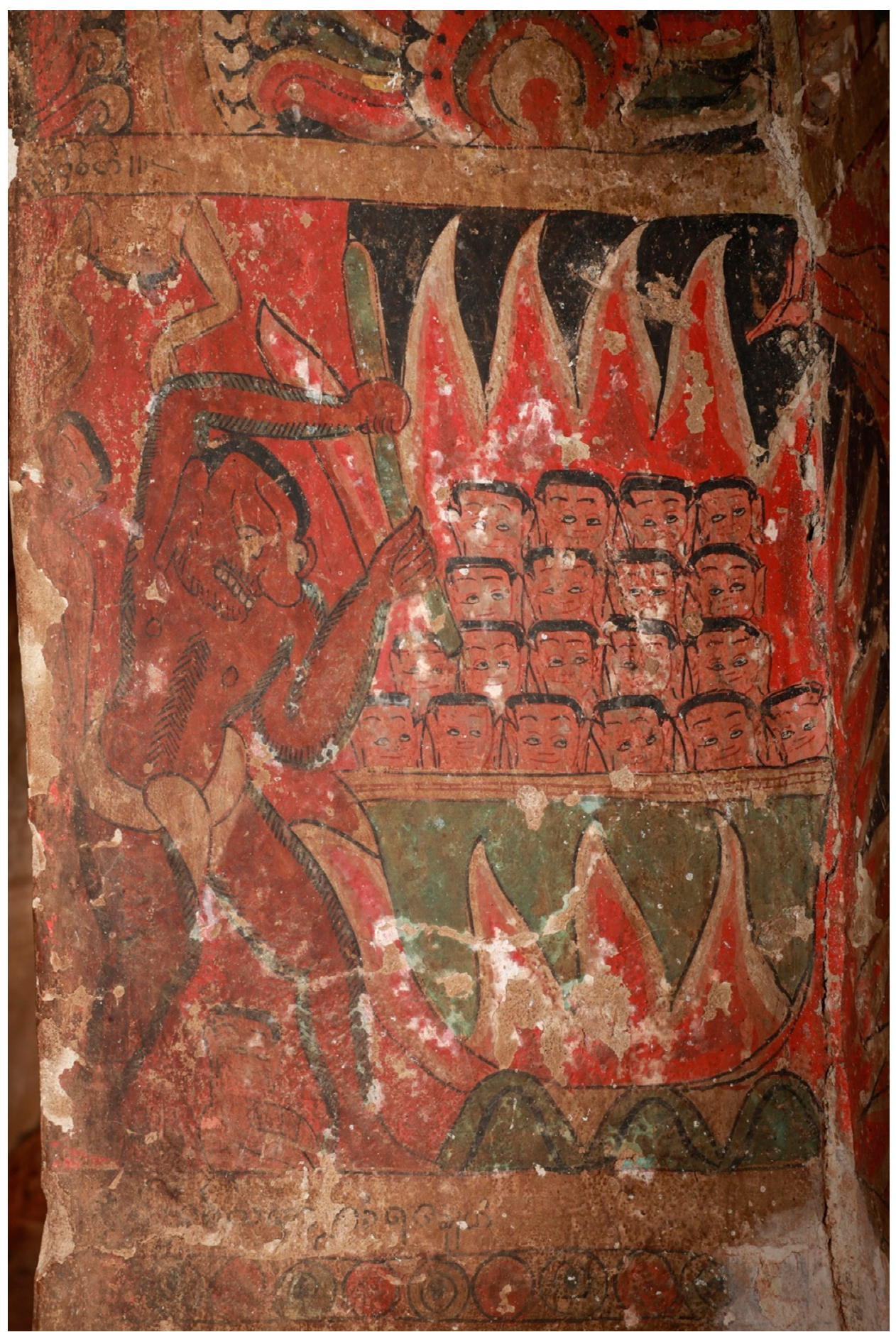

Figure 19. Anaint, Zeditawtaik. 18th century. Pots in which transgressors were cooked-one of the most popular and ancient images illustrating punishments in hell.

Shock value also informed several Jātaka narratives. In the Culadhammapāla jātaka, 358, the bodhisatta was a seven-month-old baby, being chopped up on a slab as his mother watched. (Figure 20) 


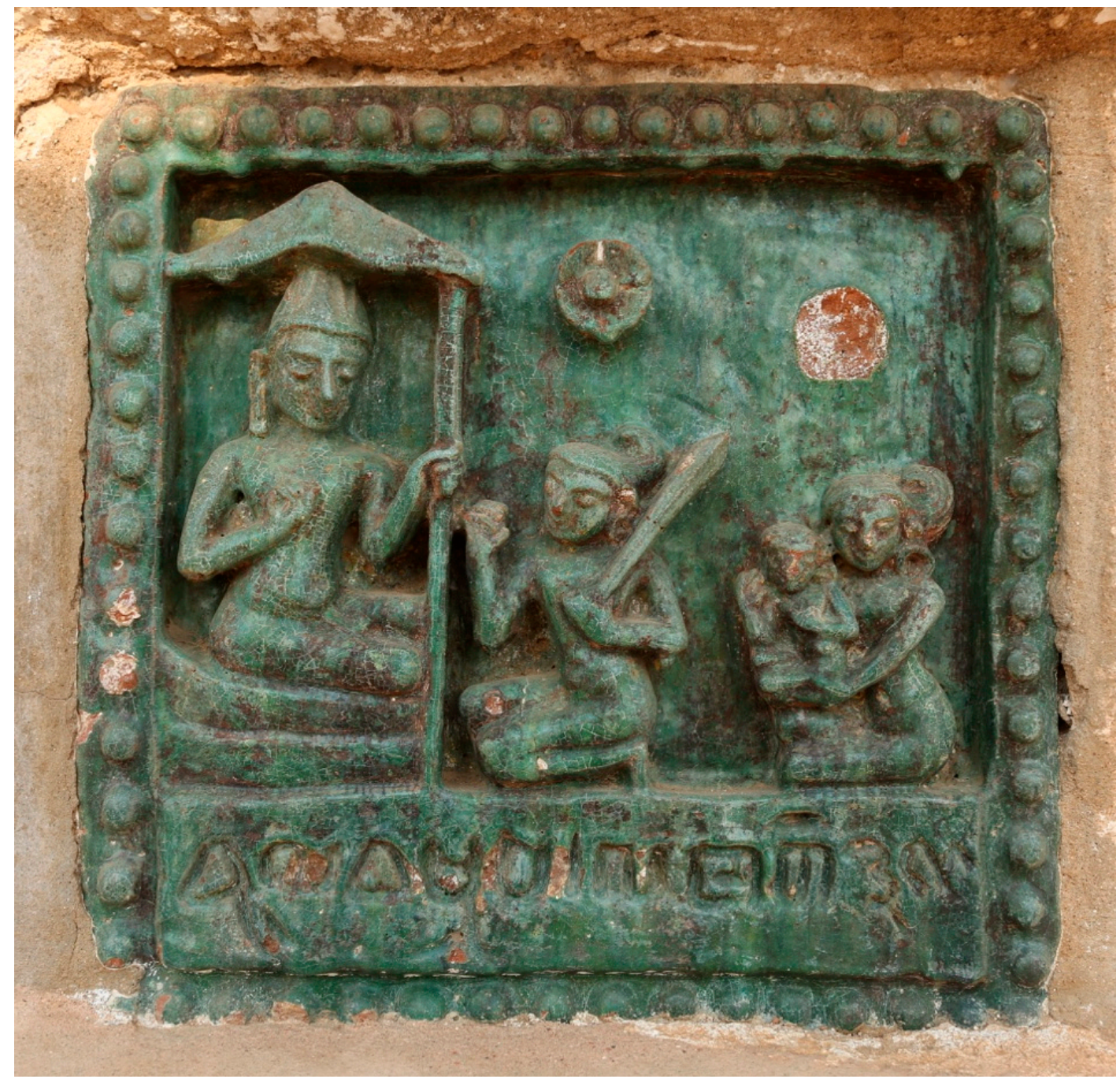

Figure 20. Pagan, Ananda 11th century. Cūladhammapāla Jātaka, 358 — the bodhisatta's mother is cradling the baby prior to its dismemberment.

The Ananda image shows the queen cradling what are, in the written narrative, pieces of flesh that had once been her son. In the painted Mon version, Indra's presence suggests a somewhat different narrative, but close enough in that, presumably, the being on the ground is the cut up bodhisatta.

In Pagan, fear as a means of societal discipline primarily focused on punishments in hells, but ghost narratives also illustrated miscreants' fate. Petavatthu stories presented remorseful spirits mourning their lot. The subject's popularity made the Sanskrit "preta" into a vernacular loan word, spelled pritta, by the 13th century. ${ }^{34}$ The Petavatthu segment of the Khuddakapattha, an independent text paralleling the Heavenly Mansions narratives, was incorporated in endowment decors, at the latest by the 13th century. The Mahāvamsa's visibility throughout these centuries, beginning circa $1000 \mathrm{AD}$, instantiates Pagan's familiarity with Mahinda's recourse to this text that made queen Anula and her entourage stream enterers. This Pali source, pivotal in Sri Lanka's interpretation of its history, was featured on the walls of the early 12th century Myinkaba Kubyaukgyi endowment, attesting to its presence and importance. A segment in its narrative recounted how the venerable monk Mahinda, Asoka's son in

34 (Win 1992, p. 53). 
this version of the story, used the stories of the ghosts and the heavenly mansion dwellers to persuade his auditors of the Buddha dhamma's reliability. ${ }^{35}$

The concept also informed donative curses (discussed below). The ghosts' actual location in the universe fluctuated; in one instance, misshapen creatures chased by ferocious pecking vultures awaiting their next meal were seen circling the outer rim of the universe, defined by its four distinctive islands, in the 13th-century Izzagona. ${ }^{36}$ An image in what is now named the Theinmazi, (13th century), distinguished the realms of suffering and bliss, inhabited alternately by the same beings, punished and rewarded in tandem, as in the case of the hunters who, because they hunted during the day, deserved their ghostly fate, but as they slept at night harming no one, also merited heavens. (Figure 21a,b) The 13th century vernacular inscription references 500 starving petas whose lot improved when a donation ceremony enabled them to eat, even making them nats (divinities) half of the time.

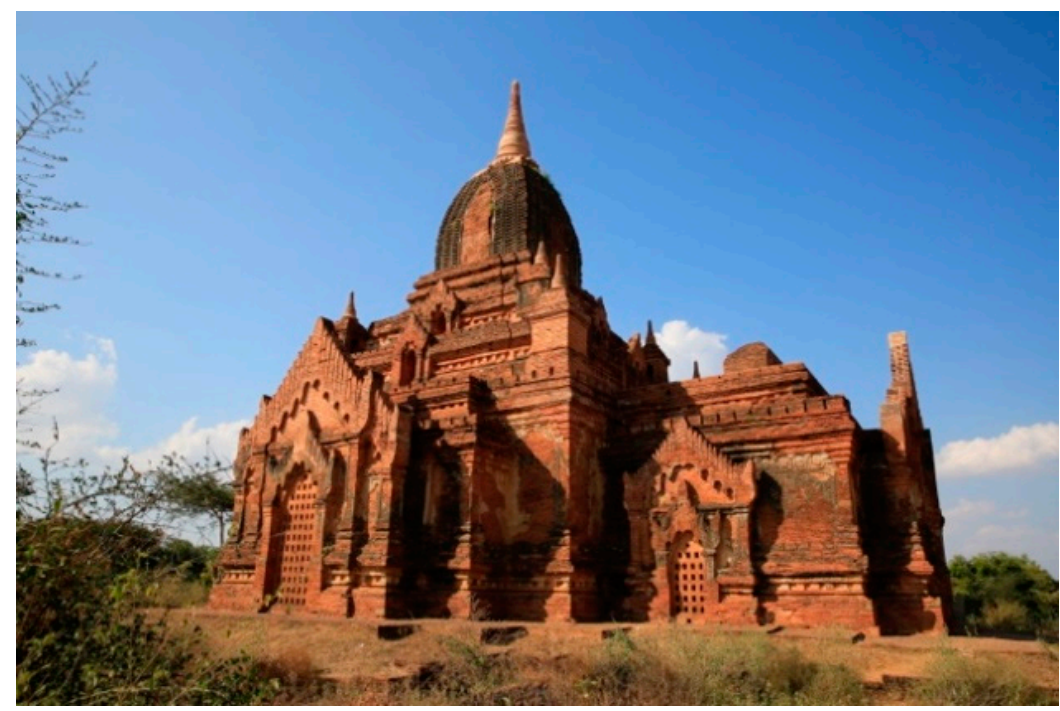

(a)

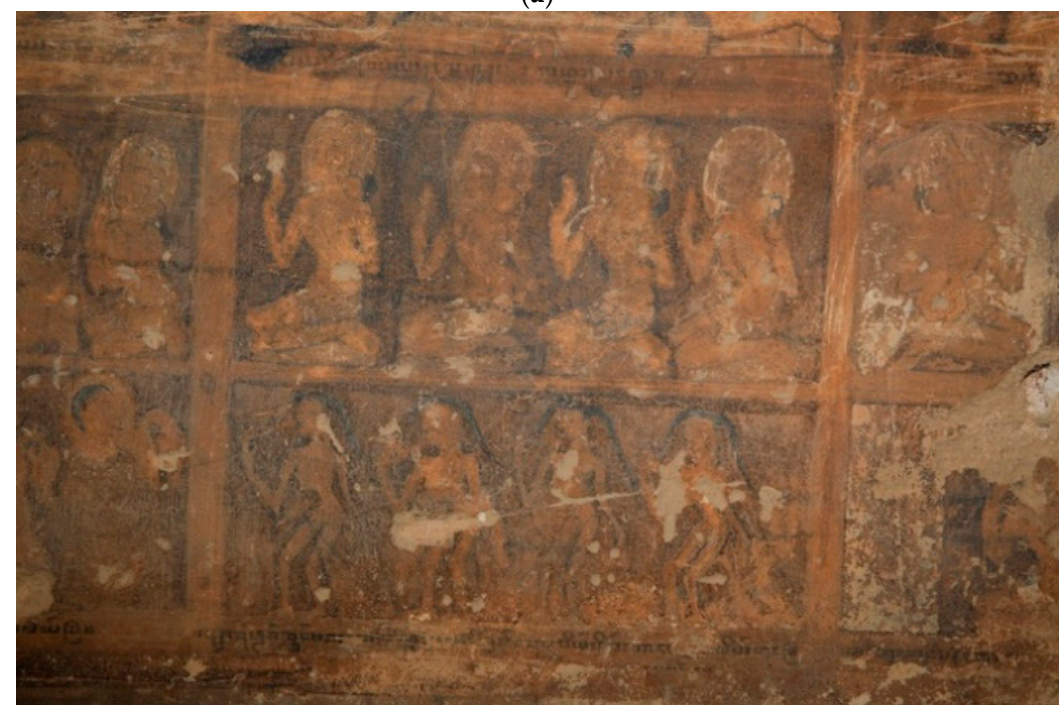

(b)

Figure 21. (a) Pagan, 13th century, Theinmazi. (b) Pagan, 13th century, Theinmazi. The fate of Petas in a story inscribed to recount their starvation, alleviated by donations made by family members. The image shows them as ghosts as well as heavenly mansion dwellers.

35 (Bullis 1999, p. 1).

36 I thank professor Samerchai Pulsawan for directing me to this location. 
Yet fear was an ambivalent device to use, making recourse to scare tactics problematic. The Teaching was itself indecisive about its utility. As Buddhaghosa showed, fear indicated inadequacy, a faulty grasp of reality, not seeing the real for what it was, being in thrall to surface appearances. The Buddha listed fear as one of four motives encouraging evil deeds, in the same category as delusion and craving. In Sanskrit texts, sangha gifts motivated by fear were deemed unwholesome. By definition, the bodhisatta was fearless, as in the jātaka translated by Sarah Shaw about the bodhisatta's struggle with what she called Yaksha Furry Hug, and as the Buddha tells the Brahmin Janussoni. ${ }^{37}$

In the Khadirañgāra Jātaka, (no. 40), fearlessness defines the bodhisatta who, bent on feeding a paccekabuddha, steps into a fiery pit prepared by Māra, whereupon a lotus springs up from the fire, facilitating his deed. (Figure 22) Sly Nāgasena performed one of his intellectual sleights of hand when Milinda wondered why arahants, by definition fearless, scampered out of the way when charged by the Nalagiri elephant. Nāgasena distinguished between mental and bodily sensations. Arahants, free of the former, were still subject to the latter. ${ }^{38}$

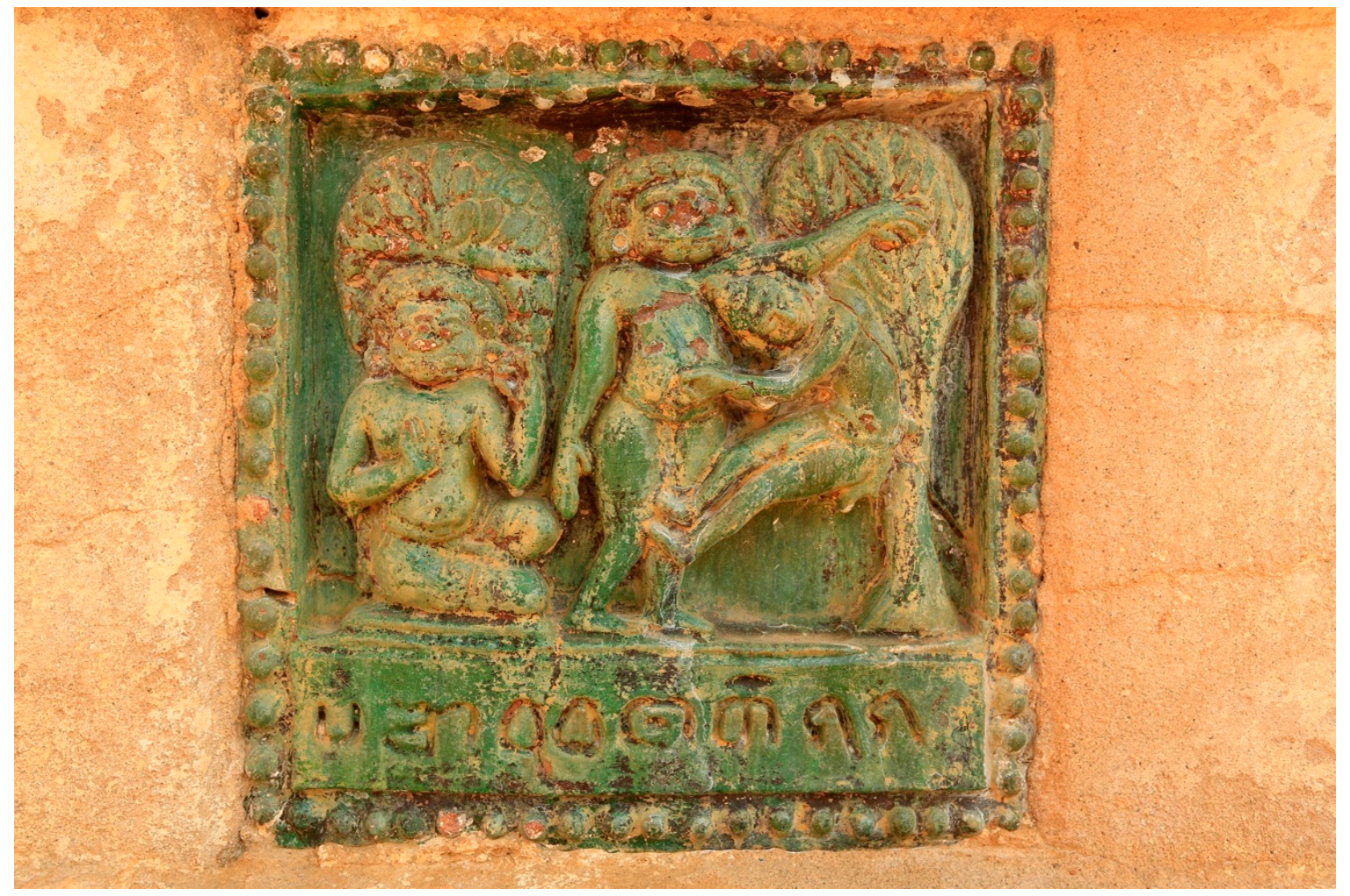

Figure 22. Pagan, Ananda, 11th century. Khadirangāra Jātaka 40.

The problematic uses of fear were overcome by the differentiation between what Buddhaghosa called "untaught ordinary beings", and, for example, monks. For the former fear was a useful cudgel because they remained ensnared by delusion that justified recourse to yet other delusions. Such was the case of the people that Māra might persuade to do evil, who were shown by him hell's fiery pits and told that they awaited people doing good. Some were gullible enough to take his perverse advice. This was also demonstrated by another story when a messenger sent by Māra was persuasive enough to encourage Migalandika to slaughter monks. The latter gladly went to their doom because they carried disgust with their bodies to its extreme (Vinaya, Pārājika 3) and were willing to have their lives

37 (Shaw 2006, pp. 55-74; Nanamoli and Bodhi 1995). Majjhima Nikaya IV: Bhayabherava Sutta. pp. $102-7$.

38 (Nanamoli 1999, III: 124, XVII: 243, XXI: 26, 29ff., 61, 69; De Silva 2018, pp. 112, 114; Woodward and Hare 2008, pp. 19, 180ff; Shaw 2006, p. 55; Nanamoli and Bodhi 1995, 102ff). 
ended, in spite of the Buddha's stress on the middle way. To make moral metaphysics operational for monks, Buddhaghosa dismissed what has been translated as "rite and ritual clinging", making allowances by default for those who were "untrained in good men's Dhamma" and thus governed by the "perverse assumptions" it nullified. The question whether good behavior generated by fear was good, received, therefore, an equivocal response. ${ }^{39}$

However, no society ever functioned without using fear as a tool of social control, and Pagan and later kingdoms were no exception. The reason was that fear was a means to shape contemporary behavior, via threats of retribution not only in the hereafter but especially in the current now, harnessing what the Pali called immediate and future retribution. ${ }^{40}$ Donors were aware of this distinction, and avoiding hell was an occasional wish.

The mechanism making such practices workable was defined by hiri ottappa, two internal checks able to reign in humans' transgressiveness and help them distinguish right from wrong behavior. Their activation depended on a sensibility empowered by performance and exercise, ideally becoming habitual, galvanized instinctively. They determined morality and ethical behaviors, cultivated not because virtue was a luxury good, but because humans were so constituted as to be improvable. The Buddha's realism insured that humans would not be asked to do what he did not believe them to be capable of. The fact that ottappa partly depended upon another emotion, fear, in the sense of moral dread in the face of wrongdoing, also recognized fear's utility. Ottappa activated a trepidation at the potential of bad consequences. Experiencing it was parsed as "shrinking in fear" (ottappati) of wrongdoing. ${ }^{41}$

The Samkicca Jātaka's story (no. 530) (Figure 23) of the present, recounting Devadatta's iniquities and his ally, king Ajātasattu's, complicity, describes the king's uneasy sleep. He is disturbed by what, in English, is called conscience, and in the Pali vippatisaro, connoting regret and remorse. In a karmic universe, strictly speaking, neither had much going for them, and atonement was also problematic since making amends provided no escape from retribution. ${ }^{42}$ However, as the story shows, "real life" was more complicated.

Buddhaghosa's dogmatic precision and assumption about kammatic inexorability dismissed the practical utility of remorse but, for purposes of daily life, it was a valuable sensibility, because of the lessons learned, making such emotions useful on the future's behalf. Contrition, forgiveness and conciliation may not have settled irreducible expiatory accounts, but they inculcated virtue and encouraged ethical behavior. All the more so given the horror of it all. Ajātasattu's nightmares conjured flesh-eating worms sucking blood, iron birds plucking tongues and rivers of floating cadavers. As such stories illustrated and the Buddha's elaboration endorsed, recognition of one's bad conscience encouraged allowances that Buddhaghosa's uncompromising dogmatism rejected. ${ }^{43}$

Ajātasattu's regret and his conundrum's resolution were inaugurated by imaginary horrors. Part of the Burmese conditioning stratagem was unpacking such bad actions in light of the hirī and ottappa that, if activated, would have prevented them from having happened to begin with. Theories of morals are always informed by how human nature is understood, a society's physiological and psychological presumptions thereby also pervading its social and political ideology. Some clues teased out of the available evidence, examined below, suggest that hirī and ottappa were part of Pagan's ideational substratum, given their presence in those parts of the Pali corpus known to have been in the public domain. The good people were ideally defined by heeding such inborn prompts.

Theaters of cruelty were on display in Pagan and later to awaken self-reproach, hirī and ottappa: self-reflexivity at work. The Buddha and, following him, Buddhaghosa, defined them as "the two

39 (Nanamoli 1999, XVII:243; Giustarini 2012).

40 (Woodward and Hare 2008, II:43ff).

41 For contextualization of these sentiments in South Asian milieus, see (Granoff 2012, p.180ff; Heim 2012, p. 238).

42 (Rhys Davids and Stede 1995, p. 628). Woodward and Hare, 5:2-5. (Granoff 2012): 185ff., Shulman: unpublished paper.

43 (Heim 2012, p. 246ff; Woodward and Hare 2008, I:42:ff, II:125, 126). 
bright qualities ... protecting the world", according to the Itivuttaka, the means of destroying rebirth. ${ }^{44}$ As exit from samsāra, however, was practically unattainable, more achievable and, at the same time, more immediately useful substitutes materialized. Confirmation of the existence of these rewards was provided by the Heavenly Mansion stories. They retained their resonance from the end of the 11th century until early modern times.

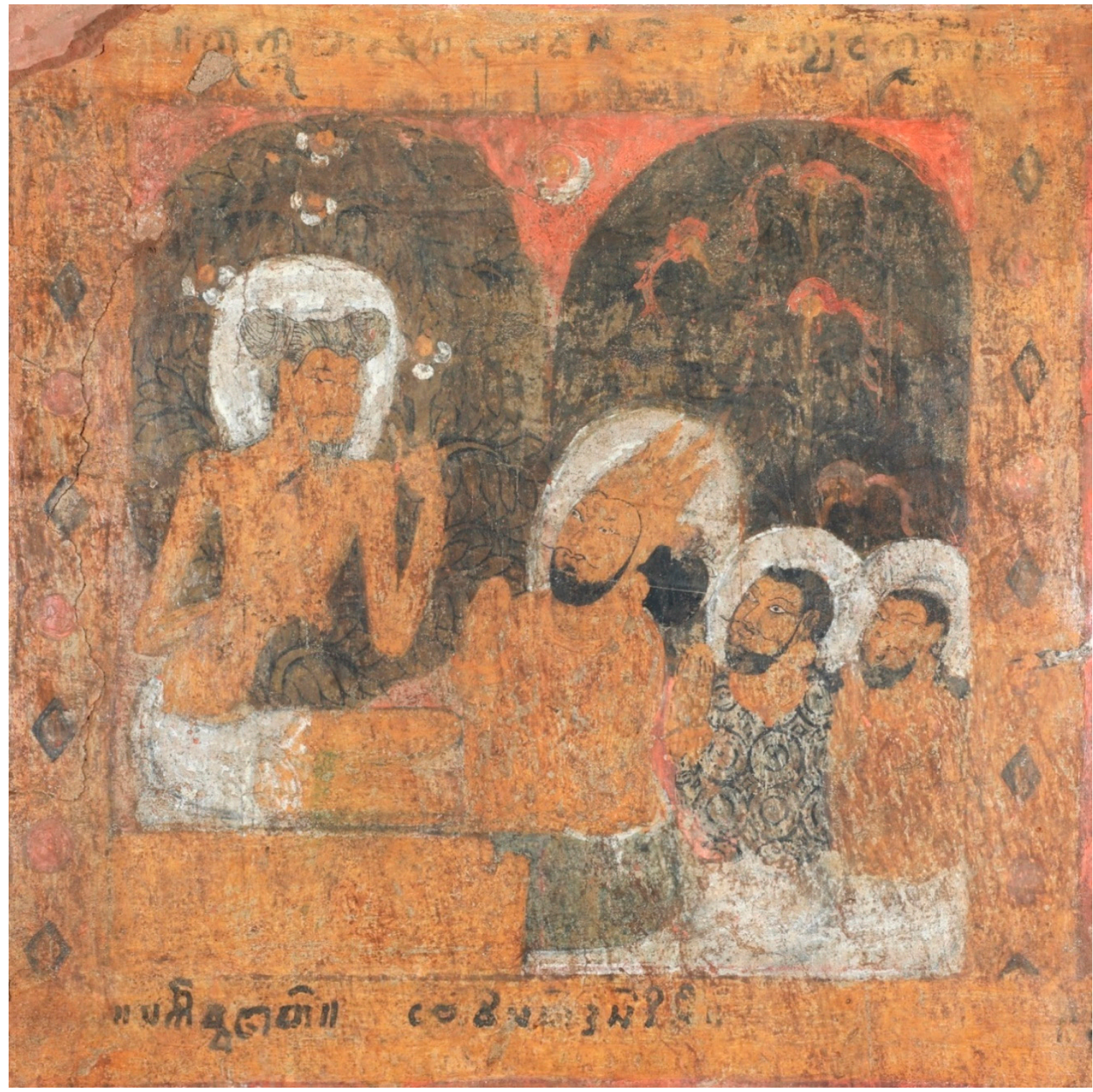

Figure 23. Pagan, Myinkaba Kubyaukgyi 1112 AD. Samkicca Jataka 530.

When the Buddha explained to Ajātasattu what the king's experience was about, he also mentioned, almost as an afterthought, what is sometimes translated as the "angel worlds" or Heavenly Mansions, described in the Vimānavatthu. ${ }^{45}$ Their Pagan and later visibility attests to the stories' popularity. Several inscriptions in the late 11th-century Alopyie, in Mon, indicate their significance; in the 12th century, Myinkaba Kubyaukgyi, two alcoves in the entrance hall, as well as in the corridor décor's lower tiers, featured the stories and their protagonists, and in the 13th century they were also on

44 (Masefield 2000, p. 34)

45 (Cowell 1994, 5: 135, 140). Mingun Sayadaw, the Great Chronicle of the Buddha, vol. iv. 
display in the periphery, in towns whose prosperity and importance related to the imperial center. (Figure 24a,b)

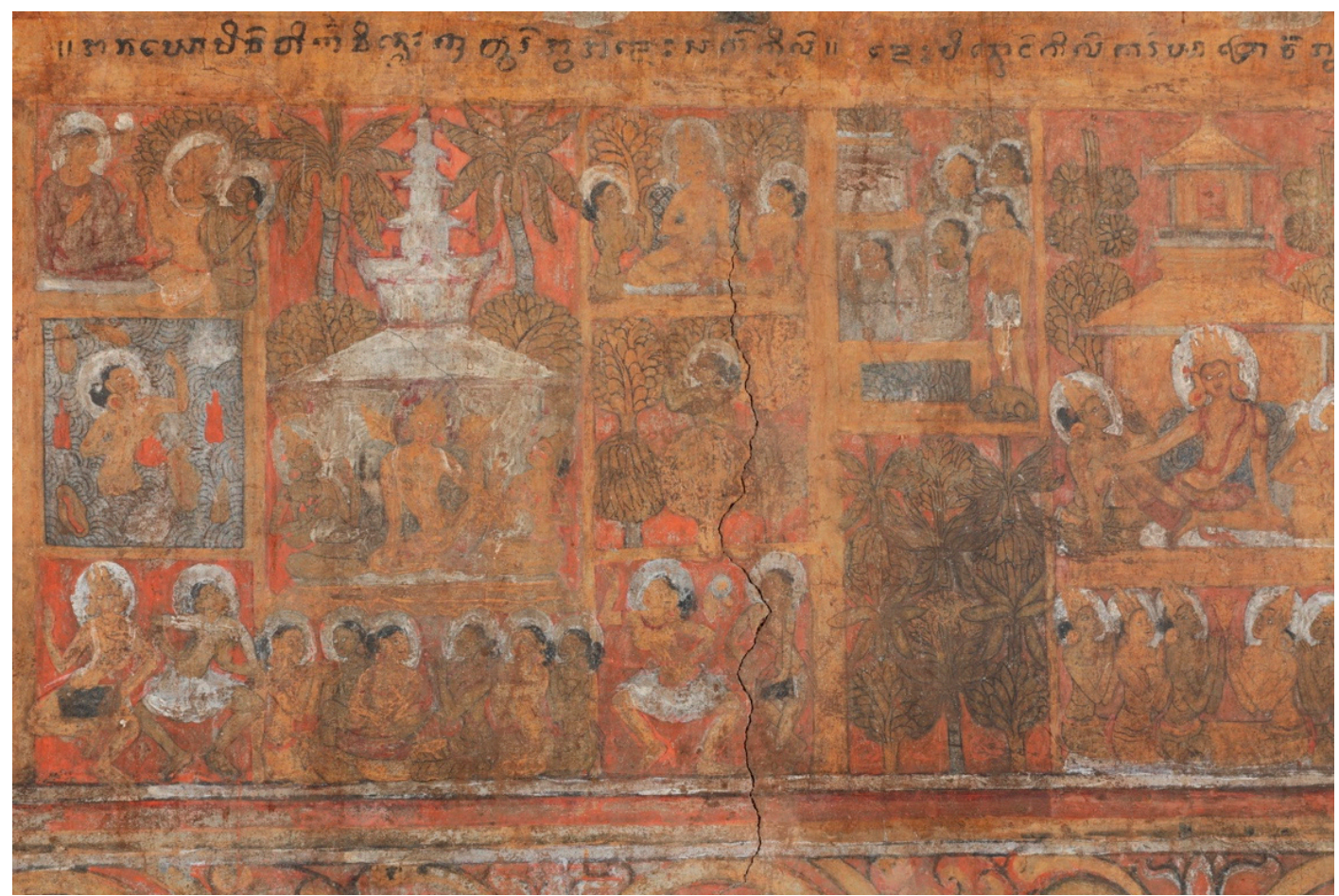

(a)

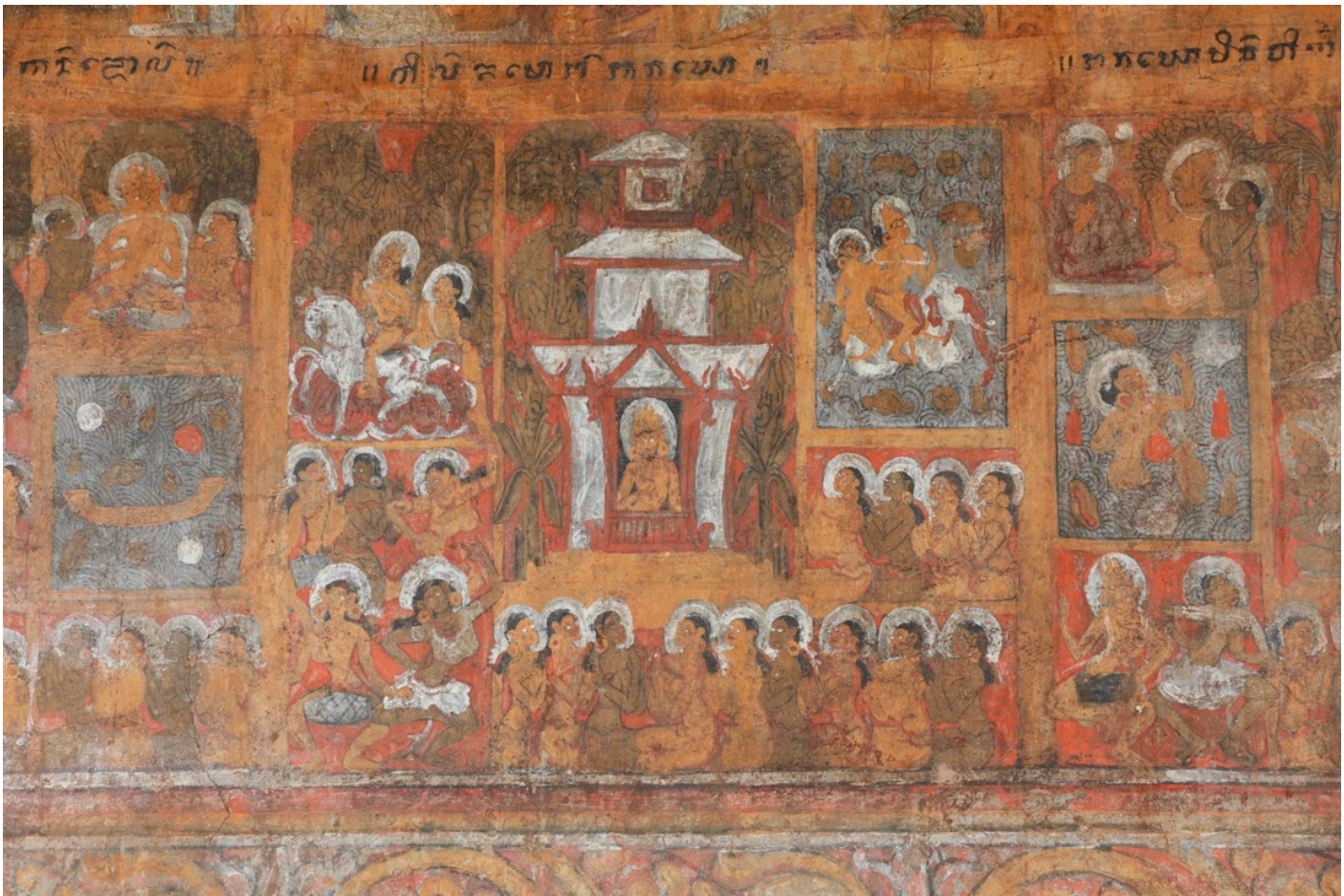

(b)

Figure 24. Pagan, Myinkaba Kubyaukgyi 1112 AD. Two Vimana stories, no inscriptions. Showing the luxurious lives of the inhabitants, surrounded by servants, orchestras, dancers, musicians, gardens and pools. (a) An uninscribed image of life in the heavens. (b) An uninscribed image of life in the heavens. 
The stories' images were always in a context shedding light on each segment's import. In 13th-century Hsale, for example, they linked to Metteya and Lokanātha, two Tooth stupas, slivers of the Siddhārtha and Gotama biography, as well as the story of king Mahā Kappina. Metteyya and Lokanātha served as 'guardians,' gracing shrine entrances, their names inscribed under their images, embodying the future (Metteyya) and another force present in the world for succor, now (Lokanātha). The tooth stupas were part of a quartet, very popular in Pagan, marking the physical presence of the Buddha's eye teeth in the universe in spite of his extinction. The stupas' images were identifiers, representing actual reliquaries—one in the Nāga realm, the netherworld, one in Tãvatimsa with the god Indra, and two in the human world-what Pagan called Tiho (Sri Lanka) and Tayok Pye, or sometimes Gandhara (vaguely referencing 'China'). (Figure 25a,b). Mahā Kappina was one of the Buddha's most distinguished disciples, who in his royal days became suffused with rupture when informed that a Buddha appeared in this world. The fascinating conjunction of these narratives in immediate proximity illustrated the forces available in this world to ensure people's wellbeing and the dhamma's multi-faceted efficacy. (Figure 26a,b).

This mattered because such narratives fostered confidence that the system was functional as explicated, that it worked to insure the just allocation of punishments and rewards. The bar for the acquisition of the latter, that is, a future in a Heavenly Mansion, was set seemingly low for its frequently downtrodden protagonists who represented society's most abject beings-poor people, exploited daughters-in law, people leading hard lives—as well as some who were better off. All that was needed to remedy their wretched lot was an act of tiny material generosity, a cup of water, a grain of rice, but it needed to be done instinctively, without calculations, indicating that their doers were in fact advanced beings, in spite of their otherwise unhappy earthly lots. This made the stories' content perhaps relatable to those who understood what they saw, and, more certainly, reflecting these bioramas' ideational composers. Among the clues that such considerations were indeed in the latter's minds was the 13th century practice of showing the Buddha addressing different audiences-omitting the titles of his suttas, and focalizing instead the diverse beings who benefited from being in his presence-fishermen, merchants, snakes, gods and even thieves. The ever flexible dhamma met all people's needs.

The prize could be a princely existence for a very long time, becoming one of Sakka's (Indra's) wives, or else, in the case of a woman so wishing, being reborn as male once her time as a goddess in heaven ended. (Figure 27). Animals' capacity to attain mansions underscored the non-rationality of what it took to get them, all the more so in that animals were said to be enslaved by fear, knowing neither hirī nor ottappa. ${ }^{46}$ (Figure 28a,b, Figure 29, Figure 30).

46 (Nanamoli 1999, I:22, 23). 


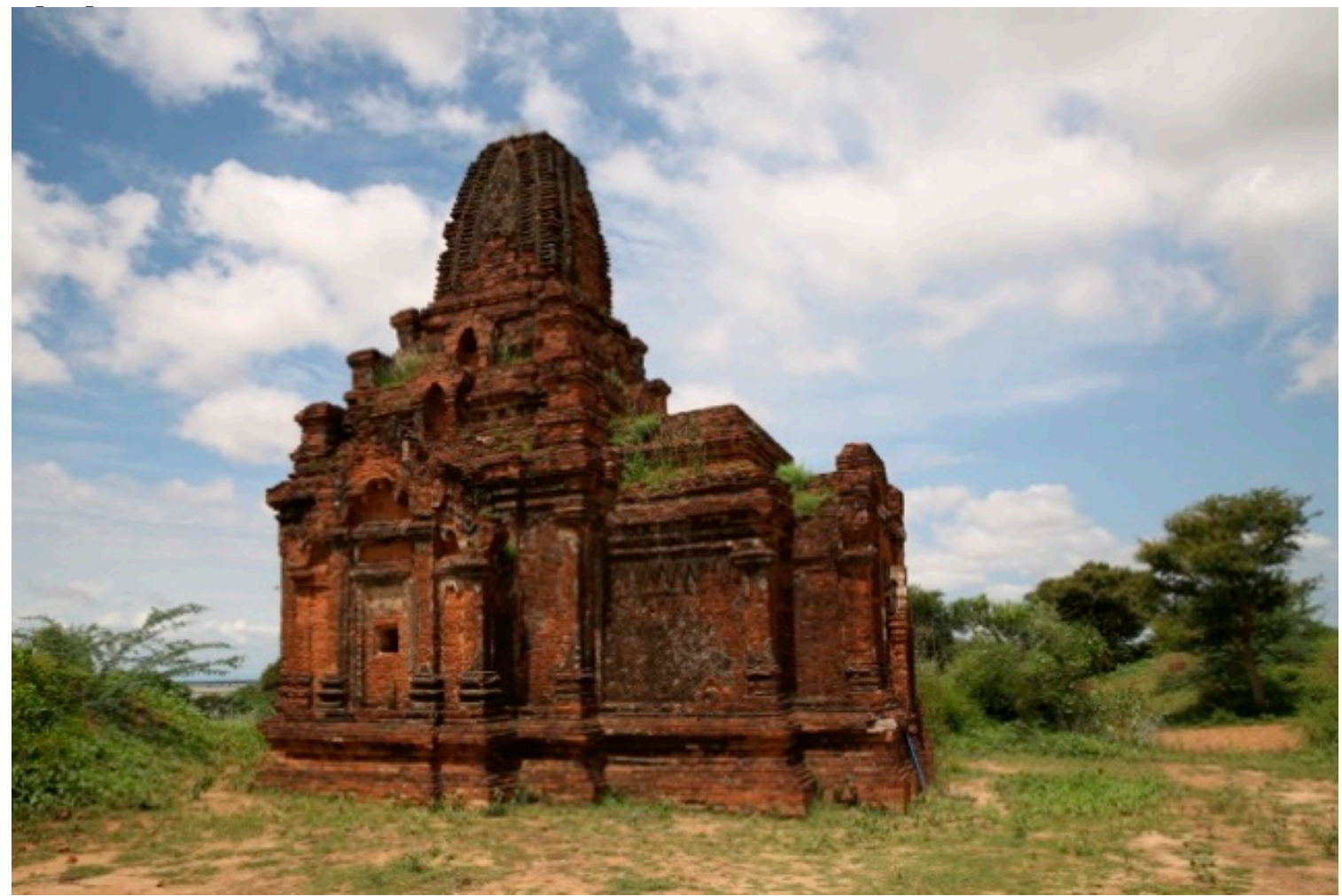

(a)

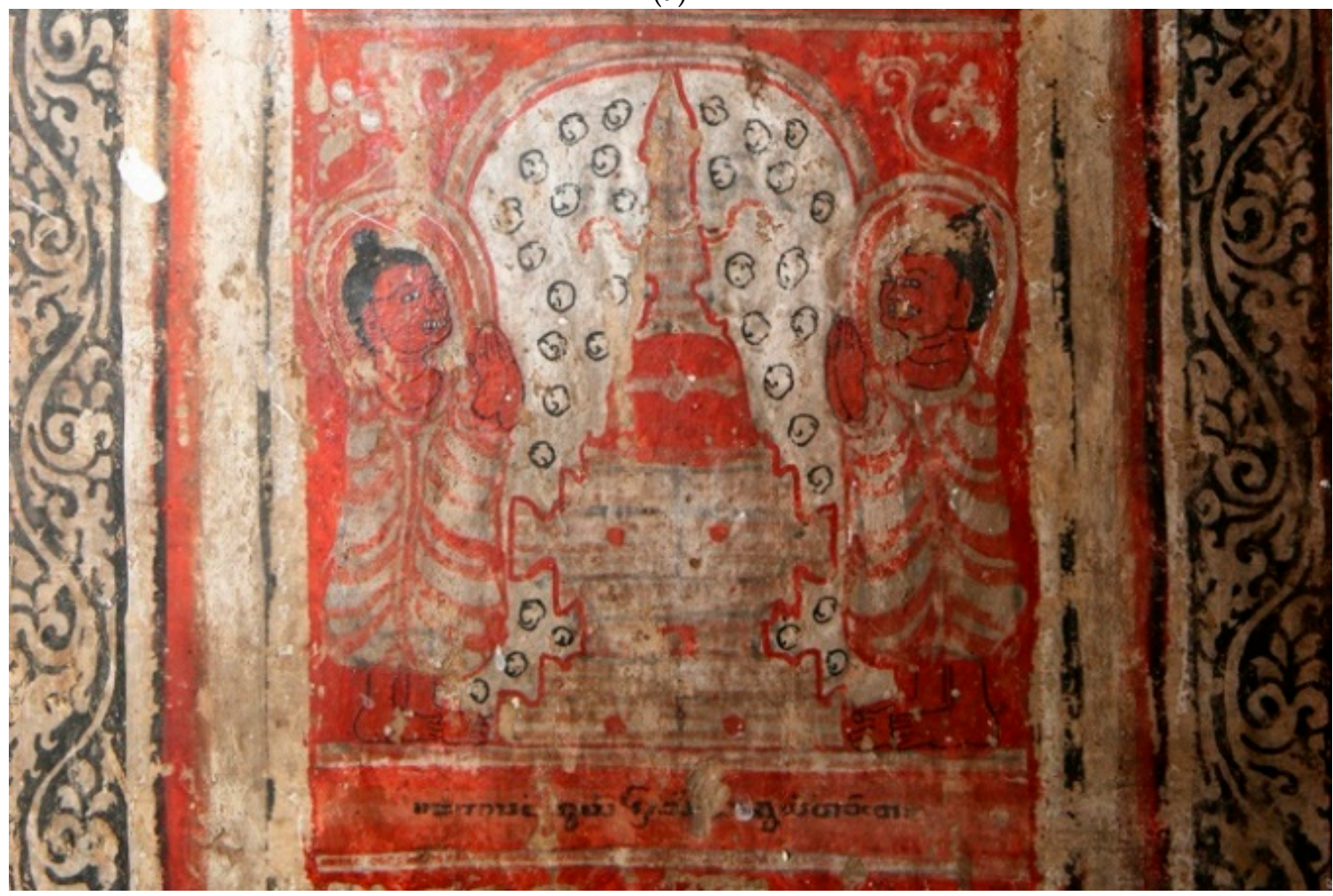

(b)

Figure 25. (a) Hsale 13th century, Endowment 13. On the periphery of the capital, numerous structures materialize by the 13th century, in satellite towns like Sale, and Hsale. This one has a well-preserved décor. (b) Hsale, 13th century, endowment 13. Two Chinese worshippers in their typical 13th century attire (as Pagan's painters assumed) revering the tooth relic. 


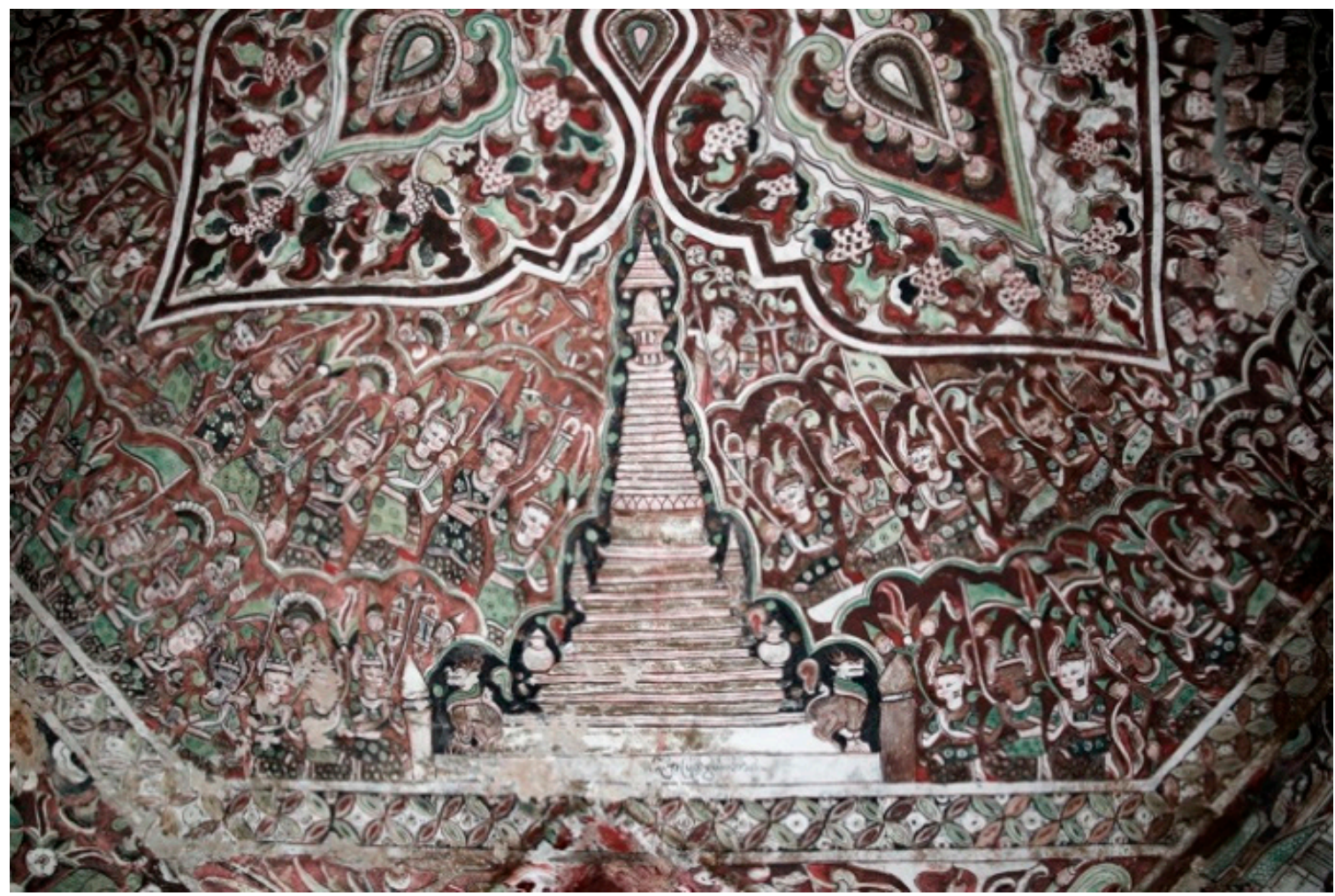

(a)

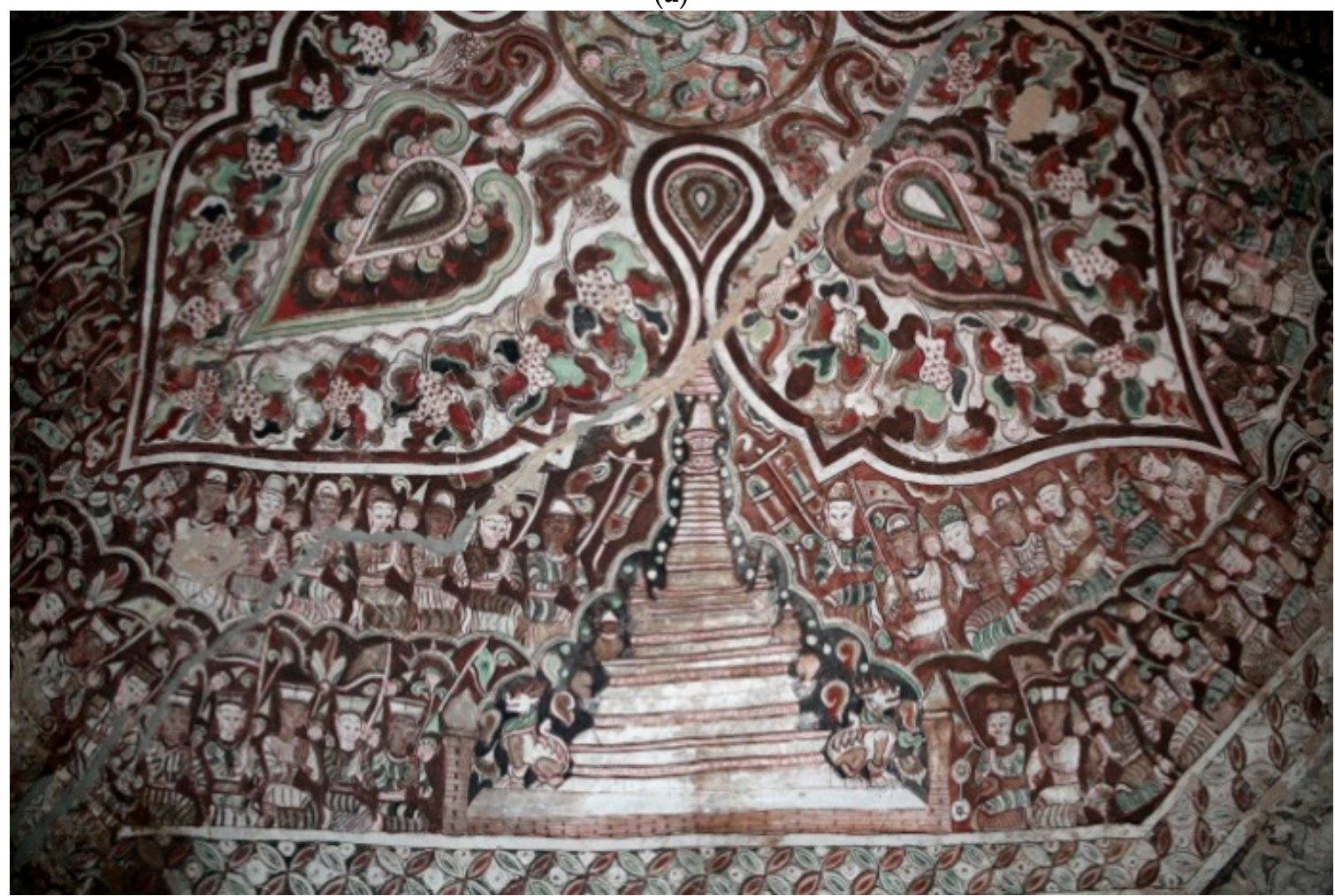

(b)

Figure 26. Powin Daung, late 18th century, cave 284. Two tooth relics. (a) shows tooth relic being revered in Tavatimsa by Indra, a tiny Shin Malae holds the broom. (b) shows a tooth relic revered by the Chinese, as interpreted in a late 18th century version. 


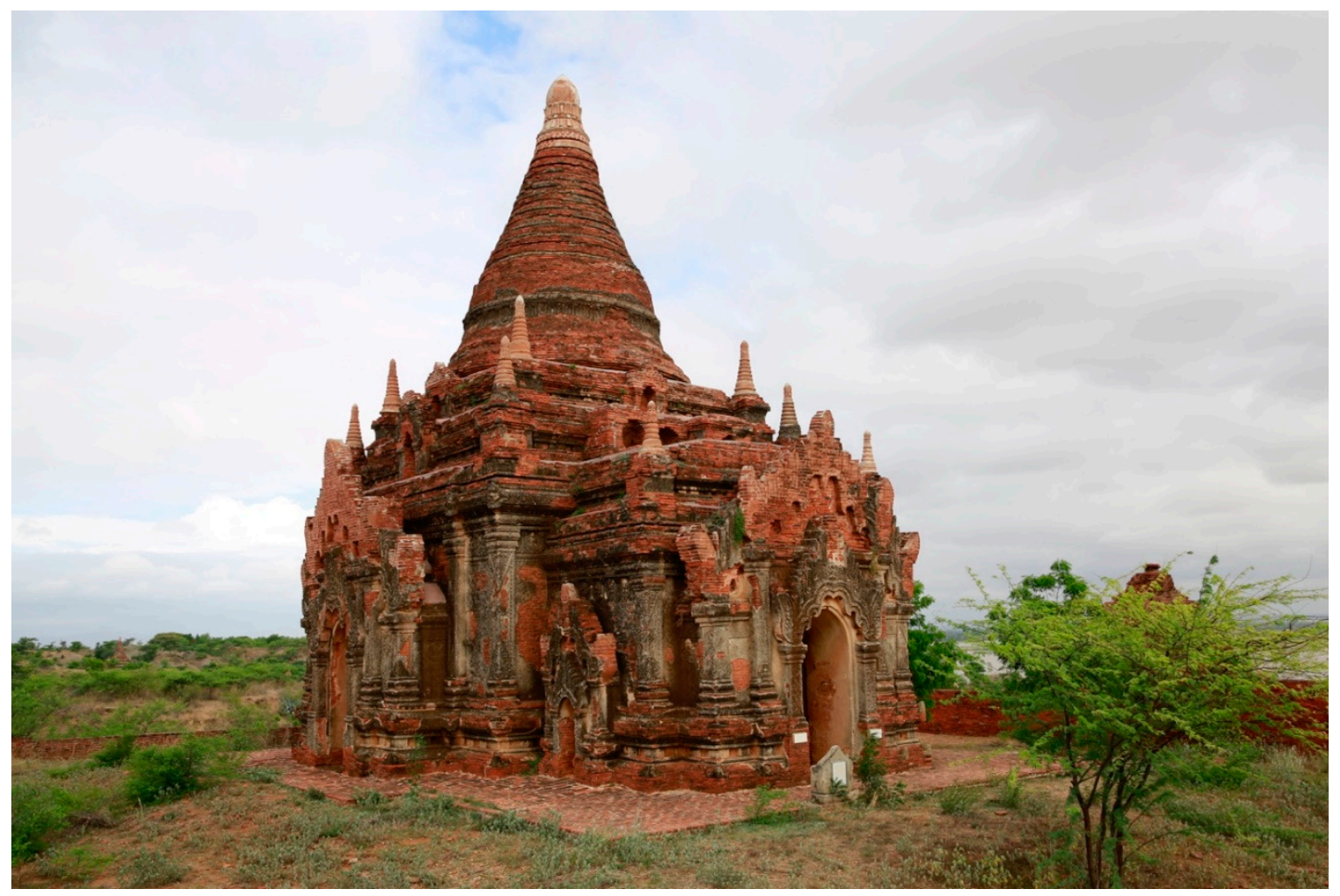

Figure 27. Nyaung U, Kondawgyi, 13th century.

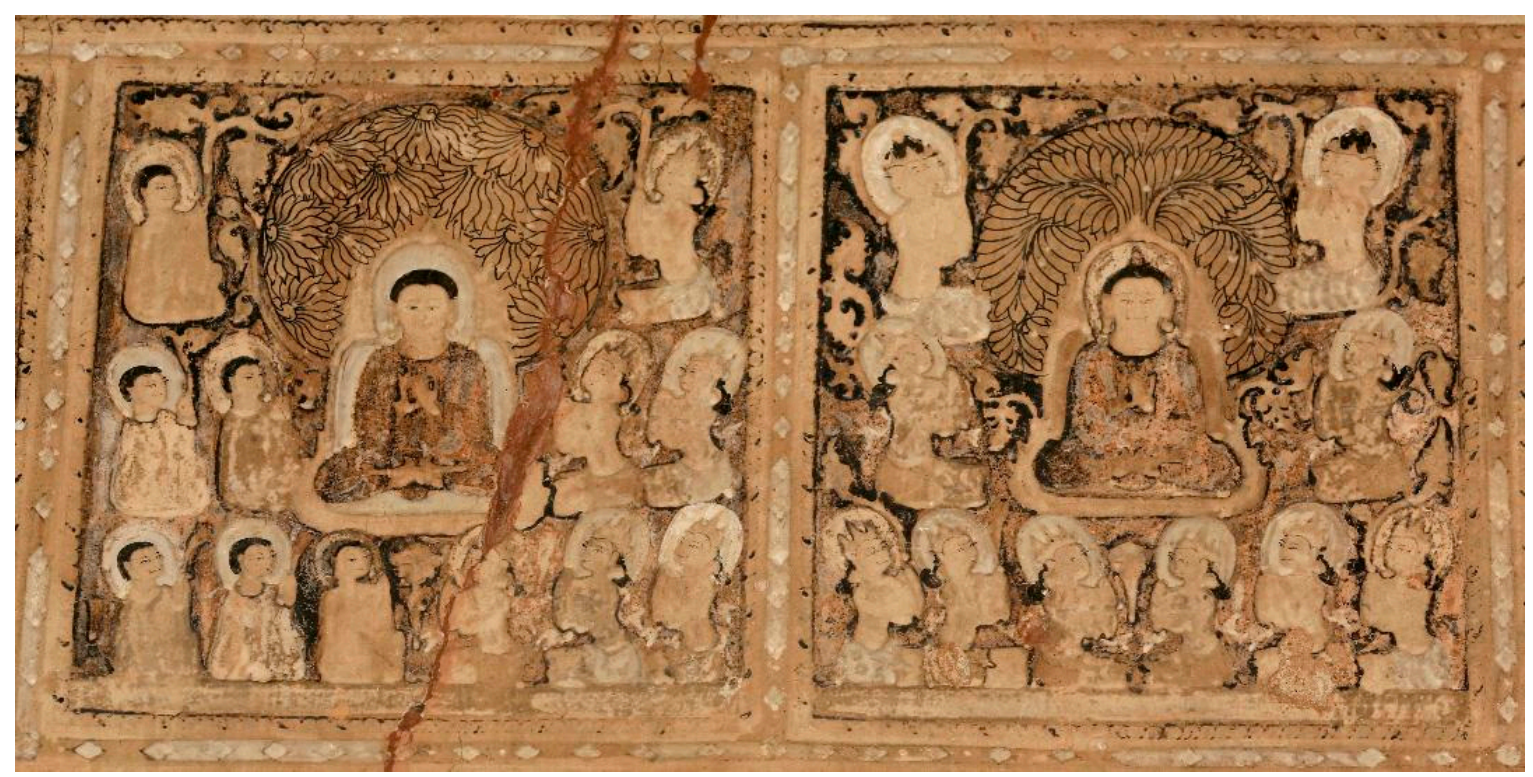

(a)

Figure 28. Cont. 


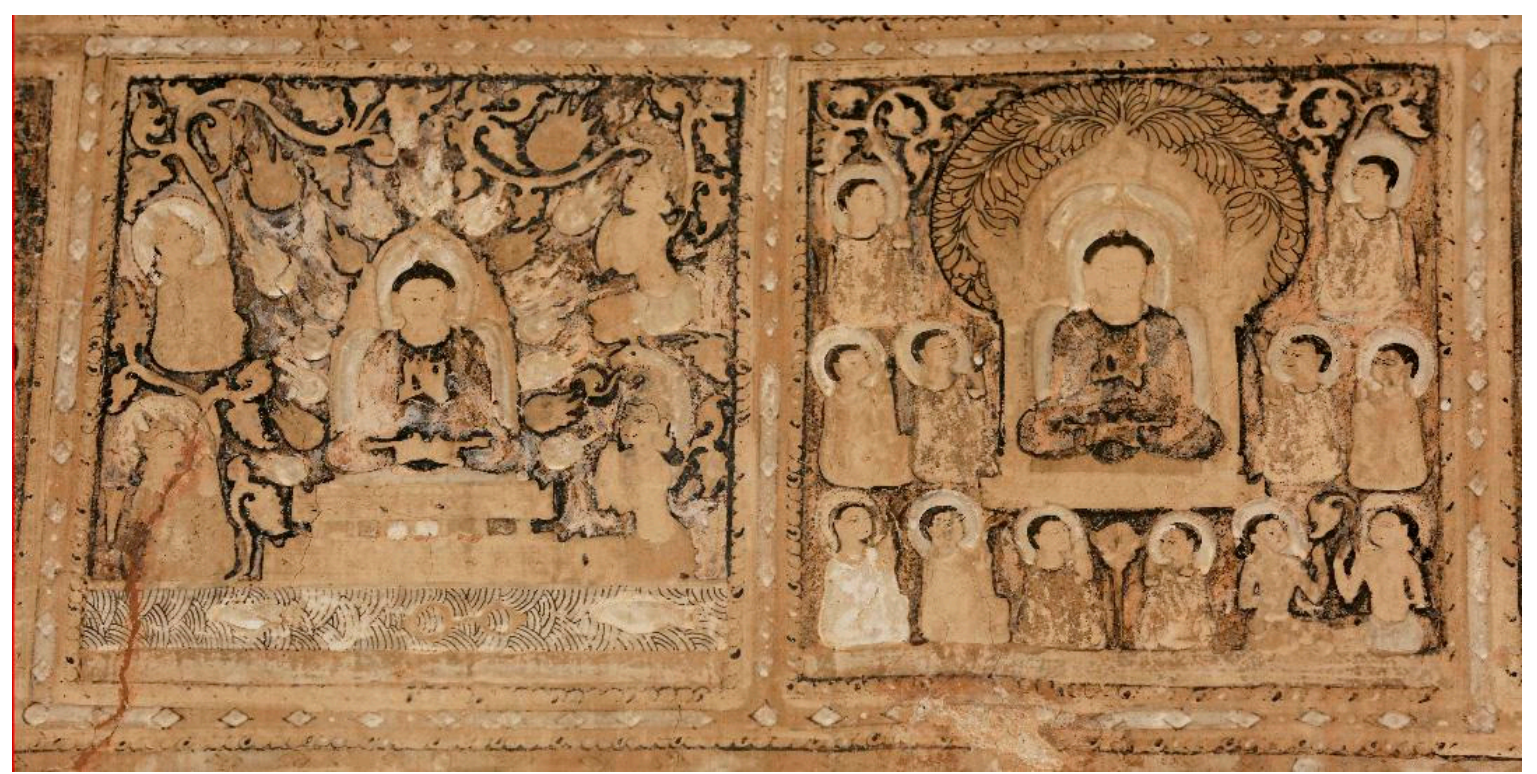

(b)

Figure 28. Nyaung U, Kondawgyi, 13th century. Four examples of the diverse audiences addressed by the Buddha, including snakes, princes and kings, monks and divinities. Inscriptions originally likely here are now missing. (a) Buddha addressing monks and Brahmas. (b) Buddha addressing nagas, monks and lay people.

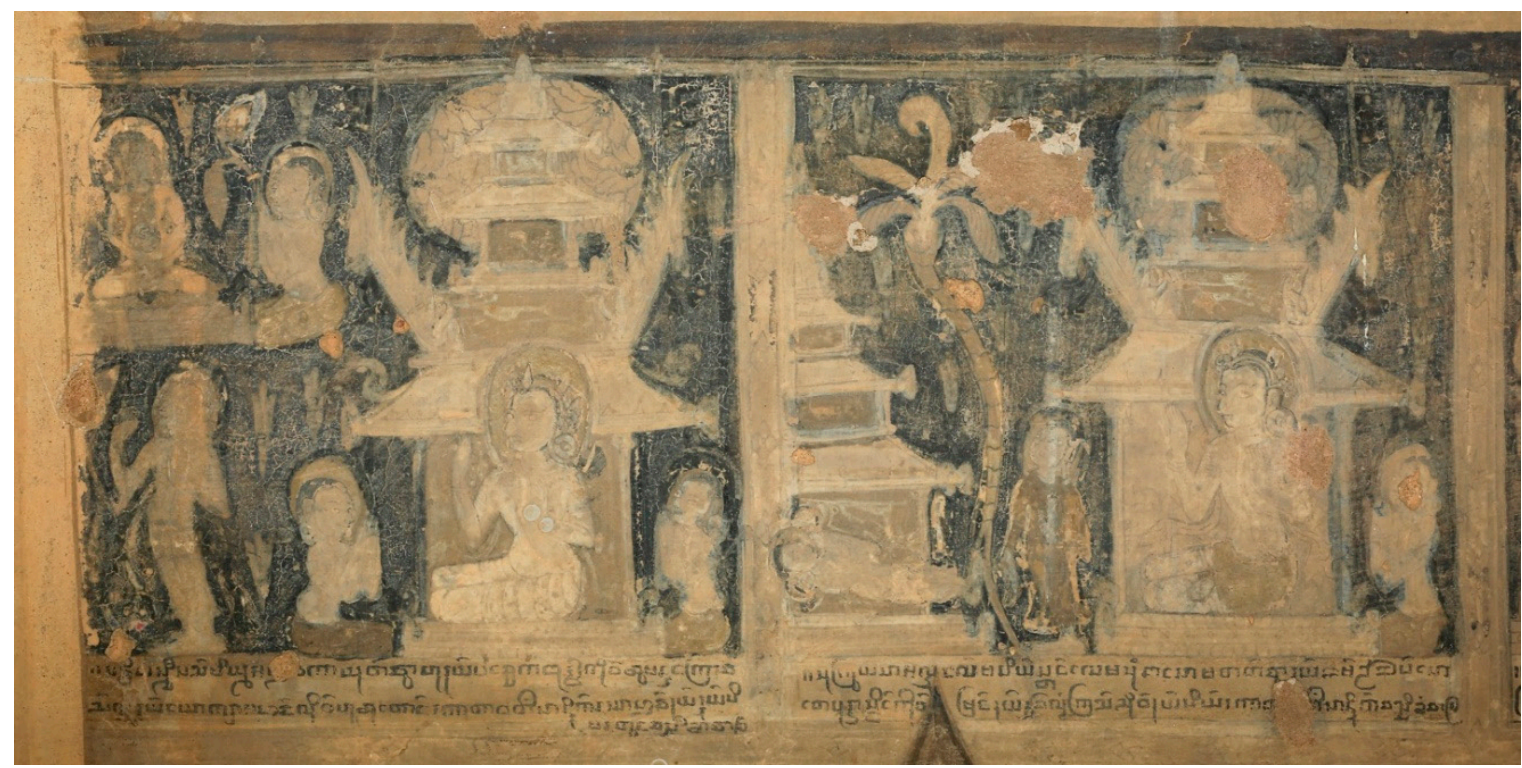

Figure 29. Pagan, Kutha, 13th century. Two Vimana images—-the left image concerning a young woman who wished to be reborn as a man, the right one showing the benefits of being in the Buddha's vicinity, his very sight guaranteeing the lucky mansion inhabitant many years of bliss in the heavens.

How the pair hirī and ottappa worked was illustrated in the story of a man who mistakenly appropriated the king's oxen. Discovering his error, attentive to the inborn protectors, and instinctively fearing the king's punishment, he fled and thus was saved. ${ }^{47}$ Nāgasena also outlined fear's wider social utility, safeguarding mores conducive to orderly lives. He used Amarā as an example. In the Mahā ummagga Jātaka (546) in terror of hell, she heeded her hirī and ottappa and remained true to her 
husband Mahosadha, he told the king. Nāgasena was trying to explain away the Buddha's charge, that the king repeated, regarding women's inherent deceitfulness. Amarā, said Nāgasena, had the good fortune not only to follow her inner prompts, but also to not be unduly tempted to stray. ${ }^{48}$

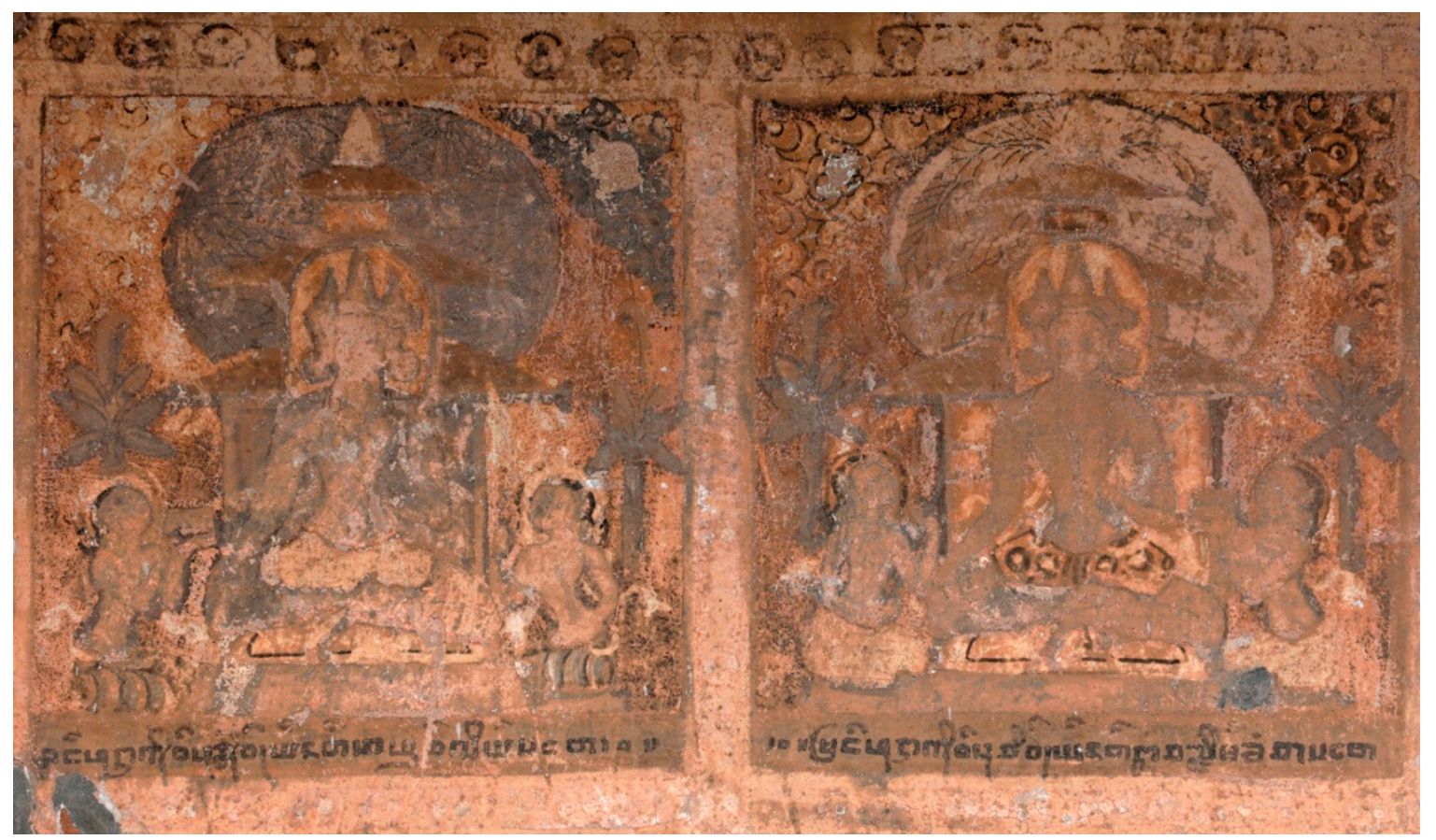

Figure 30. Pagan, Kutha, 13th century. Two vimanas allocated for animals.

Both guardians of the world, as part of human beings' makeup, were potentially galvanized by inner and outer triggers, prompting emotions generated by things seen. In the context of monastic trainings, hirī and ottappa informed interaction with one's teachers, friends, and fellow monks, but elsewhere, knowing one's place in the social hierarchy and behaving accordingly were important and merited royal attention. As the Devadhamma story illustrated, (Devadhamma Jātaka, 6) attending to these inner prompts ensured what was regarded as civilized behavior. Devadhamma, furious when his luxurious life style was reported to the Buddha, threatened to violate the rules of good behavior, only to be reminded by the Buddha how, in the past, he had been guided by hiri and ottappa, among other regulators of normative behavior. The latter meant appearing clothed when outdoors, fearing reproach and public condemnation, or, for those with means, making their achievement visible in the public domain by participating in status-affirming activities such as donating Buddha statues to a newly constructed endowment inscribed with one's name or occupation. Late 11th century artisans thereby shared in a great crown-sponsored enterprise on behalf of communal welfare. ${ }^{49}$

Hell images and the stories where they appeared illustrated the other side of the conditioning mechanism. How life would look when hirī was unattended was illustrated by the Akataññū (90) and Hirī (363) jatakas, recounting how a merchant's unkindness and ingratitude were repaid and what happened when the bodhisatta heeding his inner protectors literally experienced "disgust" in the presence of evil associates. ${ }^{50}$ This was what the "good people" did in Buddhaghosa's definition of those heeding their hirī and ottappa prompts—on their behalf, Buddhaghosa wrote his massive tome, providing instances where, for example, ignoring hiri generated bodily misconduct, not a good thing. ${ }^{51}$

\footnotetext{
(Trenckner 1880, p. 205ff).

(Heim 2012; Handlin 2012, pp. 165-236).

(Cowell 1994, vol. 3, pp. 129-30).

(Nanamoli 1999, I: 161, II: 93, XIV: 142).
} 
Buddhaghosa's influence in Pagan is hard to corroborate, but traces appear in inscriptions and also imaged décor components, as well as a reference to the "wisoddhimaga" in a 1236 inscription. Turning Dhamma adherence into a social virtue was hirī and ottappa in their mundane garb. ${ }^{52}$

Hirī and ottappa were stimulated by narratives and images among other means. (Figure 31) This might explain why prompts were sometimes so over the top in their shock value. Saigyo, mentioned above, had noted that punishing miscreants by plucking out their tongue was not only horrific in and of itself but also deprived sufferers even of the consolation afforded by verbalizing pain. ${ }^{53}$ The Anguttara Nikāya catalogued with relish hells' instruments, including the gruel pot, cutting off the top of the skull to drop in a hot iron ball; Rāhu's Mouth, inserting in the criminal's mouth an oil cup with a wick and lighting it; Flesh Hooker, being flayed with double fish hooks, and what was called the pickling process. Nāgasena repeated this to king Milinda, and similar tropes feature in the Pali and later vernacular literature. ${ }^{54}$

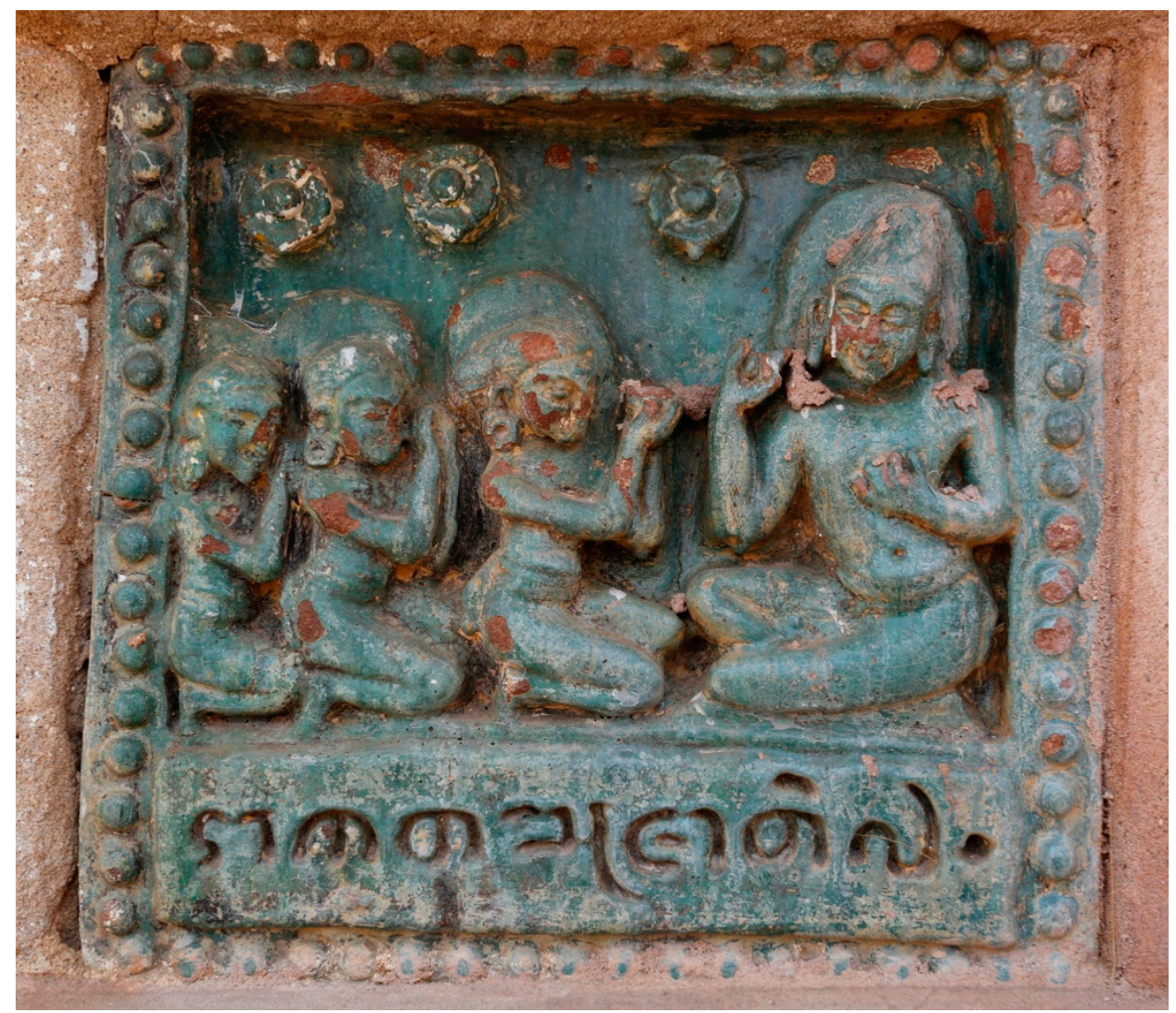

Figure 31. Pagan, Ananda, 11th century. Akataññū Jātaka, 90.

Narratives or visual encounters with depicted agonies, we know from other premodern Asian settings, evoked reflections on the viewer's life, and on the relationship between what was witnessed, its lessons and potential outcomes. The Burmese vernacular for 'fear' was a variant of the Pali bhaya, that by the 13th century had various Burmese spellings, intending to encase the term with the connotation that, presumably, contemporaries elicited from the Buddha's sense of the term. To spare beings from hell, strong arousal measures were legitimate and were assumed to work. 
Furthermore, in addition to monitoring people's future lot, fear was exploited on behalf of their present lives. ${ }^{55}$ (Figures 32 and 33a,b).

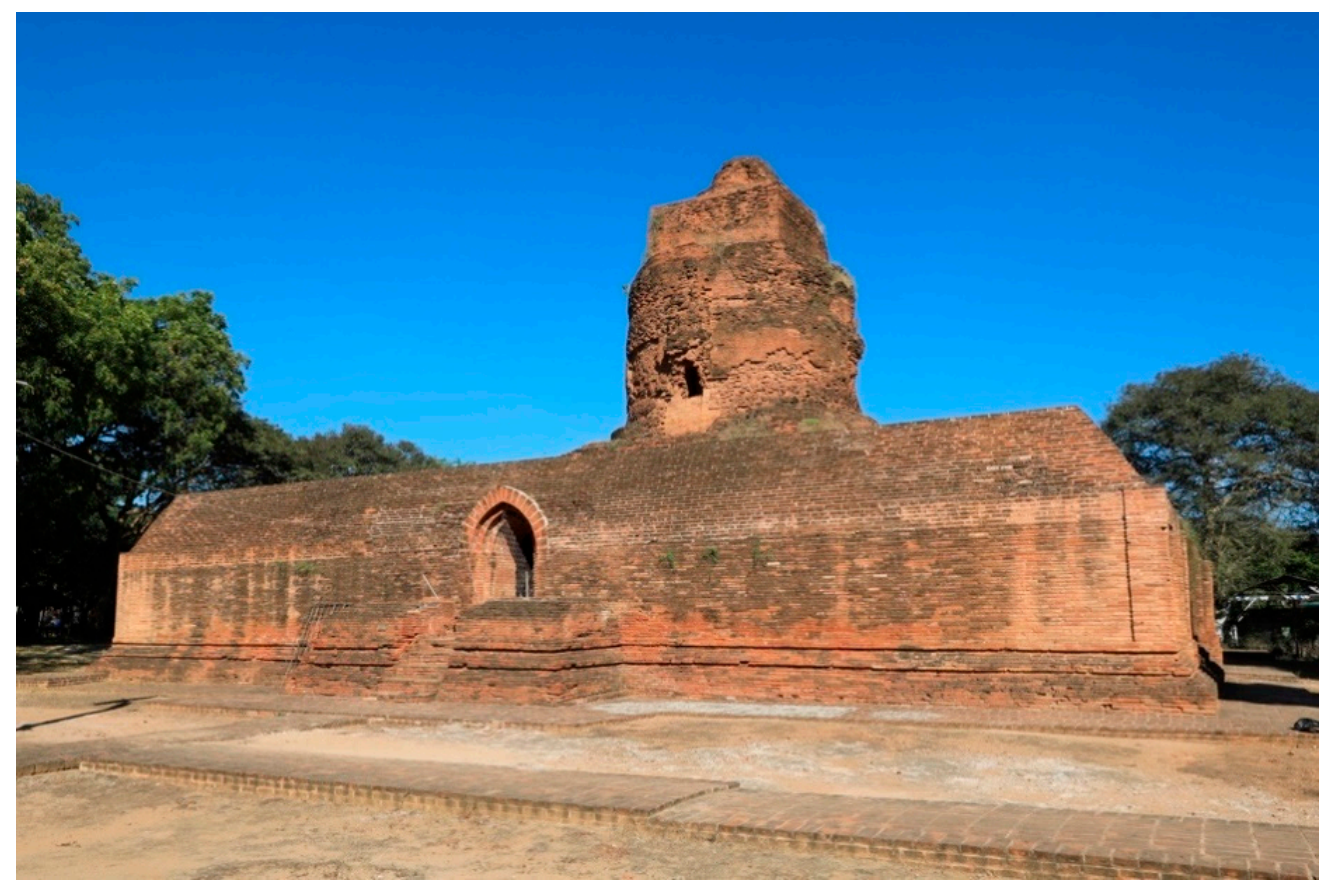

Figure 32. Pagan, Hpetleik Stupa, 11th century. Several hell images survive at the entrance to an encircling corridor featuring jataka plaques on both sides.

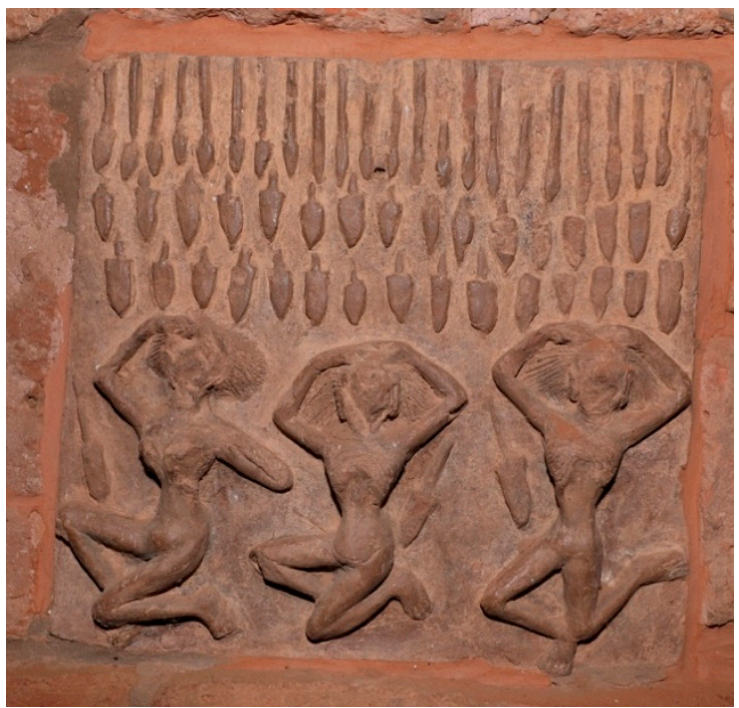

(a)

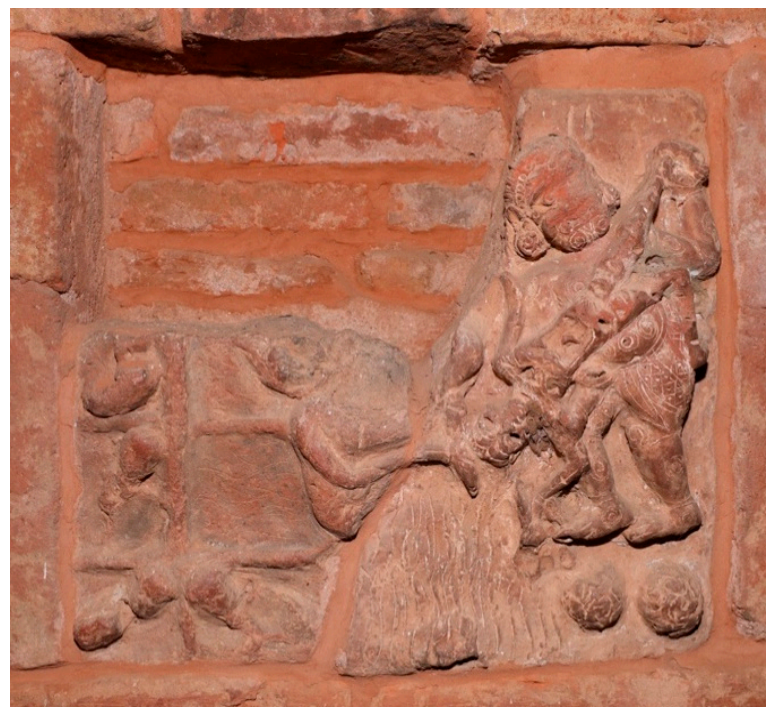

(b)

Figure 33. Pagan, Hpetleik Stupa, 11th century. Two uninscribed hell images one showing denizens being showered with sharp weapons, in the other a ferocious demon holding victims upside down is shoving them into a fire. Surrounding the latter images were other candidates, tied up, awaiting their turn. (a) Punishment by swords raining from the sky. (b) Punishment by being shoved into the fire. Missing are images of the bodies awaiting their turn.

55 (Sorensen 2012, pp. 2-45; Heim 2003, p. 533). 
The Vinaya, like other texts Pagan used (segments of the monastic code were featured on the walls of an 11th-century endowment), recorded how emotions like fear or yearning triggered responses. One story was about a monk who described the joys of heavens so persuasively that his listener, longing to get there, promptly died and indeed ascended there. By contrast, another monk wanted his auditor dead; his description of hells' horrors was so effective as to frighten the man to death and, as he was already destined for hell, he indeed went there. ${ }^{56}$ Burmese visual prompts were variants of similar strategies meant to make humans better than they otherwise would have been, becoming what the kings called "the good people". Pagan and later Burmese dynasties' version of the politic assumed the state apparatus existed to promote the human good in Dhamma terms, and was not just a hedge against upheavals, which a late 11th-century royal proclamation defined with the Pali term antarāya, disorders, suggesting not only quotidian problems but also the kind the Buddha warned against. ${ }^{57}$

In this world, people had what royal proclamations called "duties." The concept referenced the fulfillment of specific roles that were often hereditary, and whose societal standing linked to occupational differentiation and stations. Failure to behave accordingly led to hell. Social hierarchy reflected karma, making "kamma" in the Pali and Burmese spelling, the one domain where humans were stripped of all social attributes and the person was alone to confront his or her future lot. Notions of hell therefore could play on fears, insecurities and uncertainties that this unique setting, the individual standing alone, thrust upon people. What kamma meant precisely for contemporaries is impossible to unravel; over Pagan's centuries its spelling varied, suggesting the language's unsettled written format but also, perhaps, indeterminacy. A circumscribed human agency did not relieve people from personal responsibility for their lot but, as images of wishing trees that materialize in the early pre-modern period indicate, for example, in the 17th century Thirimingala, there was cause for hope ${ }^{58}$ Concerns with hells and heavens featured precisely because both settings were linked to human accountability, making hell the one great equalizer; being sentenced there was equitably distributed regardless of one's standing in the earthly hierarchy.

\section{Interiorities}

One setting where these notions were on public display were the endowments manifesting the Buddha biography. These complex visual tapestries were displayed in what in the 12th century were called gandhakuti(s), that is, perfumed chambers in which a Buddha dwelled, or, more popularly in vernaculars, derived from the Pali for cave, guha, linked perhaps to the Old Mon guh, or else ceti, the Burmanized Pali cetiya. Changing designations, as mentioned earlier, are also indicative of shifts in what was imaged and where. The taya (vernacular Burmese word for dhamma), that became the kingdom's official ideology, the source of its social vocabulary and norms, foregrounded subchapters of the Buddha's life, in which human beings' future state was a sub-trope. By the second half of the 11th century, hell images were inserted into the visual program augmenting a stupa's significance; heavenly vimānas survive from an interior décor about 30 years thereafter. ${ }^{59}$

Hell and heaven images aligned future and present concerns because the two were faces of one coin. Adultery, for example, violated a precept, and was punishable as the Nārada Jātaka (544) showed, by years in hell and numerous rebirths as a castrated being. However, marital stability was also a social good, encouraging authorities to foster precept keeping, at least in theory. To clarify this, Pagan's and later dynasties' structures' interiors became visual libraries where hells and heavens were featured in narrative or other contexts.

56 (Nanamoli 1999). III: 95cc.

57 See (Handlin 2012).

58 Thirimingala Inscription, unpublished, 17 century donative notification.

59 The term gandhakuti was used by contemporaries during the early centuries of the second millennium. (Pe Maung Tin and Luce 1920, p. 63; Win 1992, p. 17). 
Two patterns materialized. One included these cosmological slivers within longer narratives, or else they were shown as stand-alone elements. Both presentation versions were accompanied by inscribed captions that clarified what deeds, behaviors or activities merited either destination.

Examples of the former are the paintings of the Nārada and Nimi Jātakas in the early 12th century Lokahteikpan. (Figures 34 and 35a,b). These two stories belong to the last of the Jātaka books, the Mahānipāta. Because of their association with the attainment of the parami(s) (perfections necessary for Awakening), they were depicted in extenso, as opposed to mono scenically.

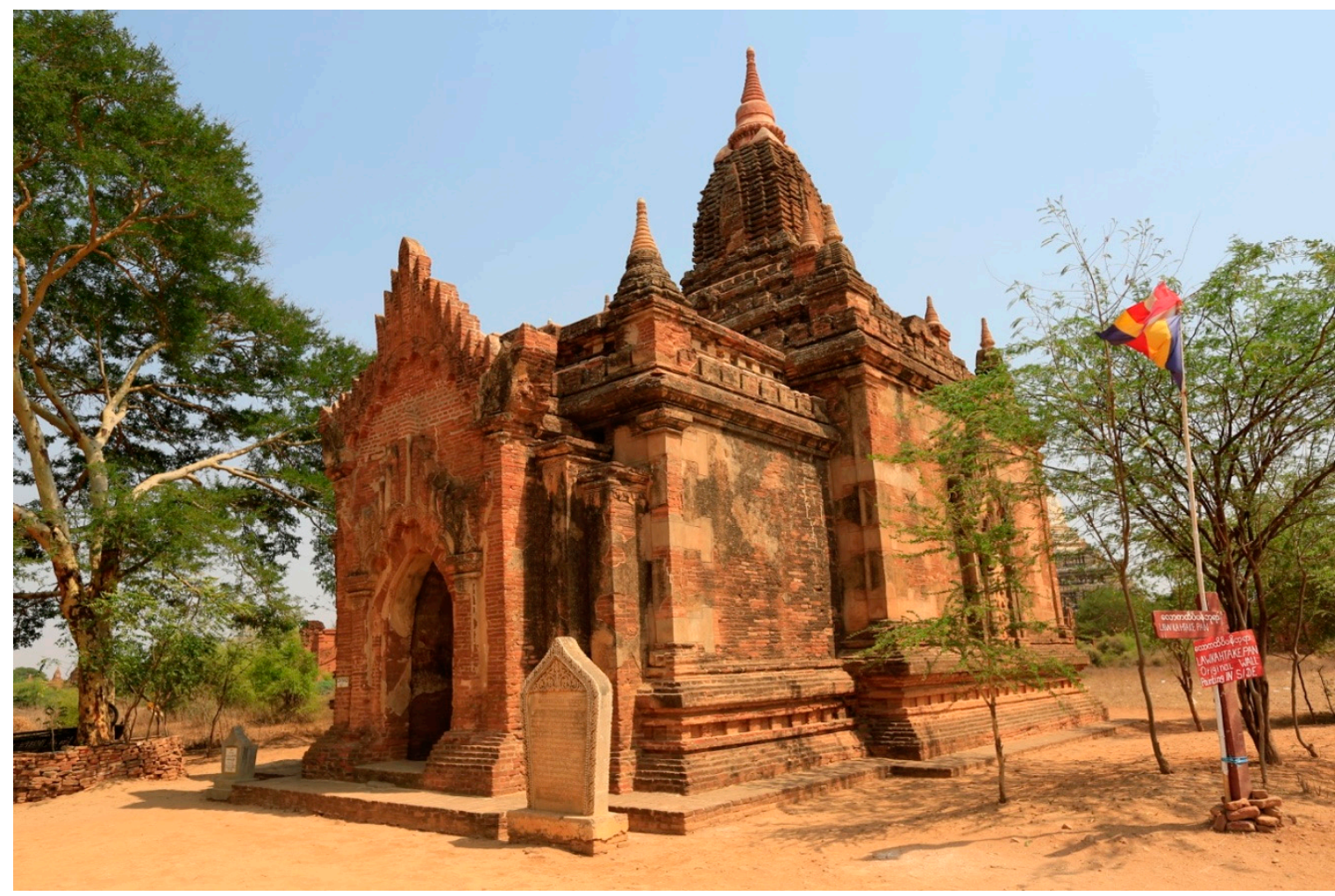

Figure 34. Pagan, Lokahteikpan, 12th century.

The Nimi Jātaka (541) (Figure 36a,b) was particularly useful because it included a long list of transgressions, theft, murder, adultery, lying, malicious gossip and anger among them, comprising bad deeds impacting individual, communal and family relations. Unfortunately, Pagan evidence does not clarify whether the list merited attention. In later centuries, as will be shown below, Nimi's itemized catalog achieved great visibility, though by then, other, vernacular, sources were also available for their enumeration.

Nimi's visits to the hells and the heavens also resonated somewhat differently among the two (in the early centuries most visible) ethnic groups making up the kingdom's mixed population. The Burmese and Mon likely used a similar rather than identical canon. The Mon interpreted the Nimi Jātaka in a limited number of frames, allocating each realm one image.

This was not governed by how the story was visually presented: in this instance, glazed plaques featured on top of a stupa crowning a royal endowment from the end of the 11th century, now called the Ananda. The Nārada Jātaka was likewise abbreviated. By contrast, other Mahānipāta jātakas were detailed, the Vessantara in more than 120 panels. Meanwhile, on a painted gandhakuti wall inscribed mostly in Burmese, dating to the early 12th century, the Nārada and Nimi Jātakas were more comprehensively visualized. (Figure 37) 


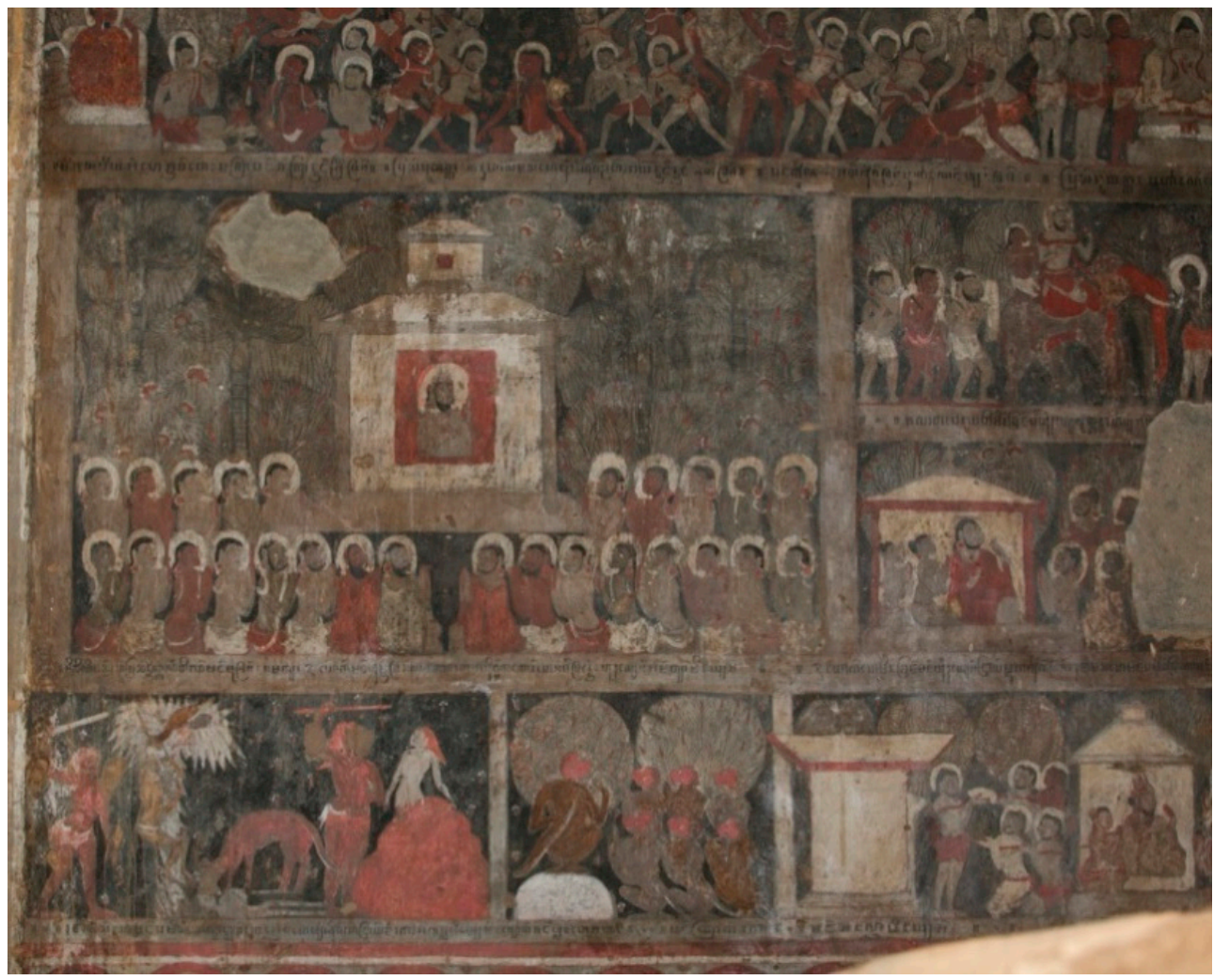

(a)

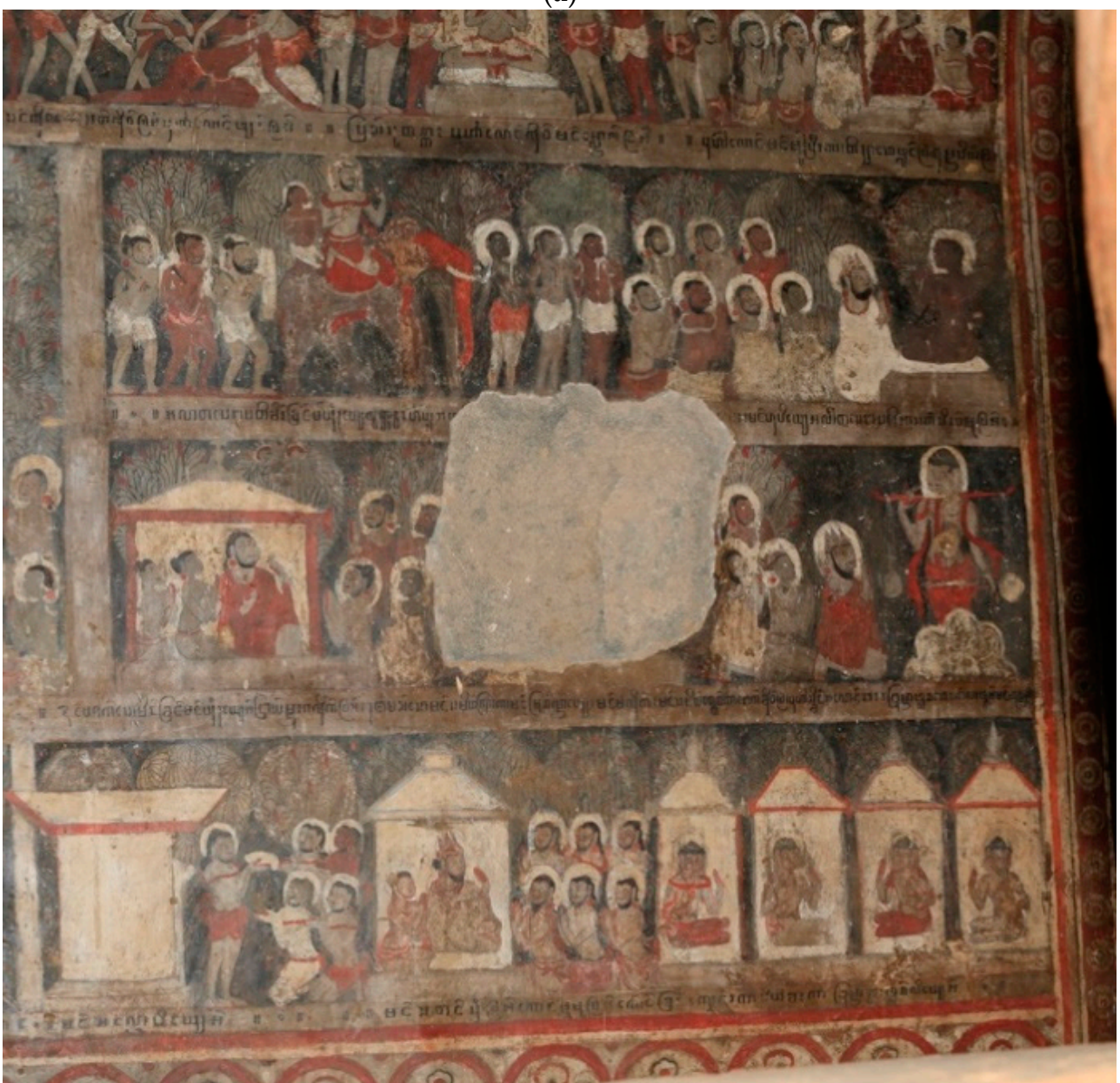

(b)

Figure 35. Pagan, Lokahteikpan, 12th century. Nārada Jātaka. (a) First part of the Narada Jataka narrative. (b) Conclusion of the Narada Jataka narrative. 


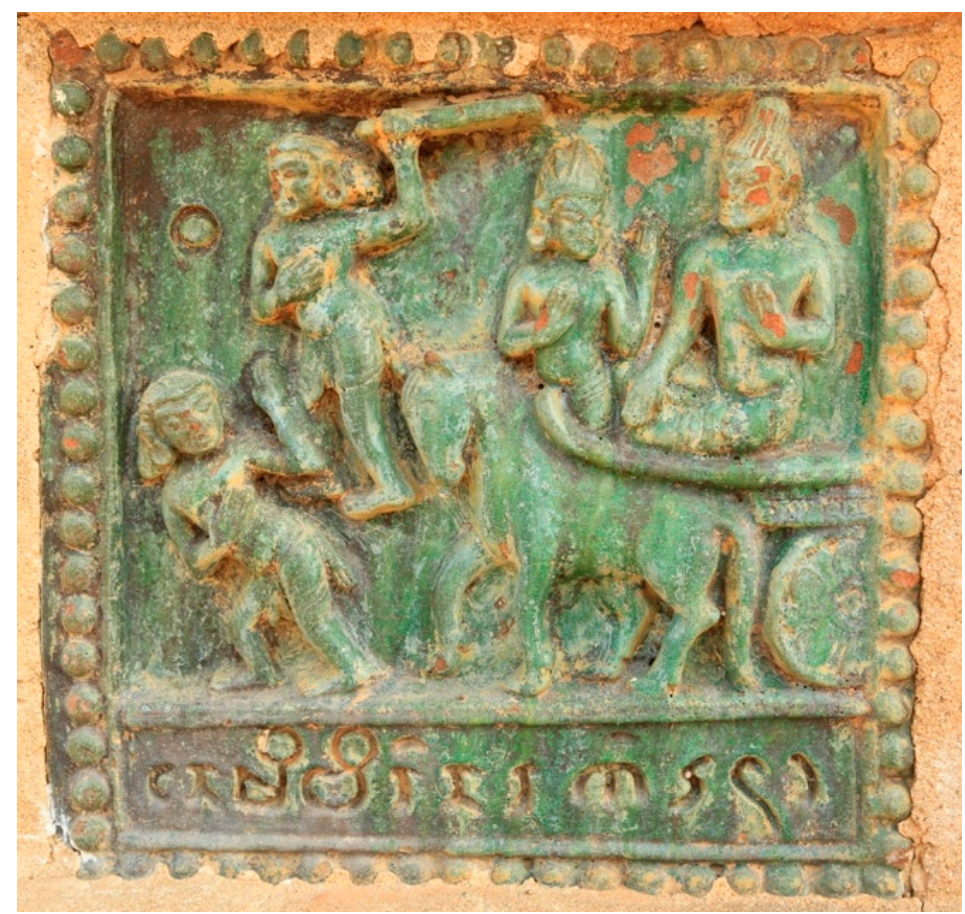

(a)

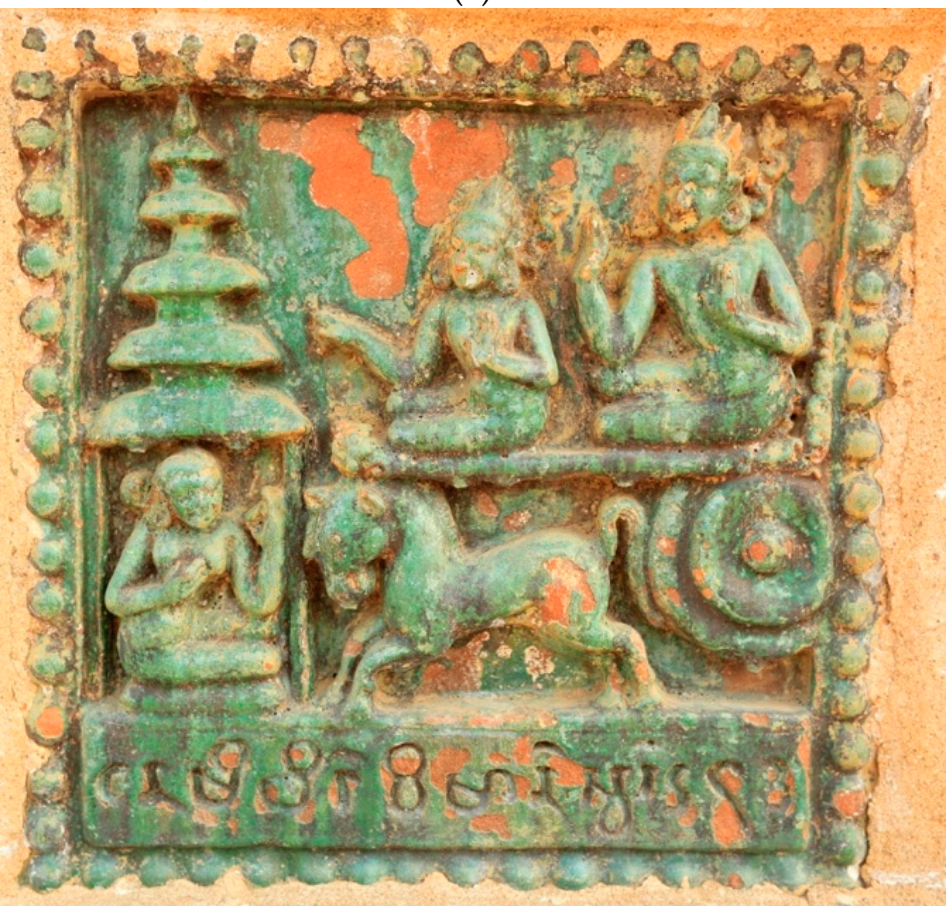

(b)

Figure 36. Pagan, Ananda, 11th century. Nimi Jātaka. (a) Nimi visits hells., (b) Nimi visits a devi in her vimana.

The other format made hell scenes independent components focused on particular behaviors and their result. The earliest extant example of this pattern was probably on the outer side of a hollow stupa, dating to the 11th century-now called the Hpetleik. Graphic hell images, often inscribed with 
the names of particular hells or transgressions, introduced the rest of the stupa's visual décor-the entire series illustrating bodhisatta lives. ${ }^{60}$ (Figure 38a,b).

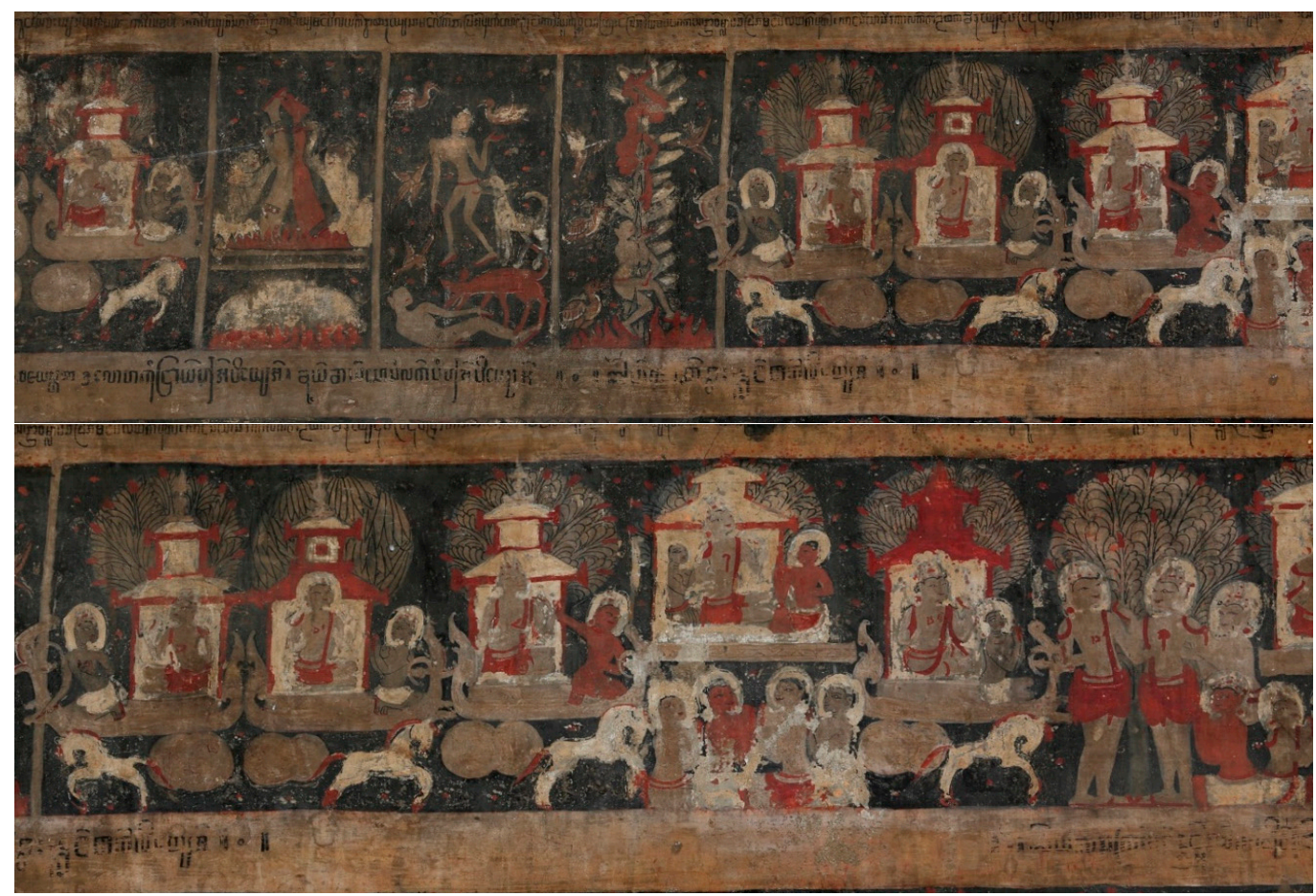

Figure 37. Pagan, Lokahteikpan, 12th century. Two segments of the Nimi Jātaka-visit to hell and visit to one vimāna.

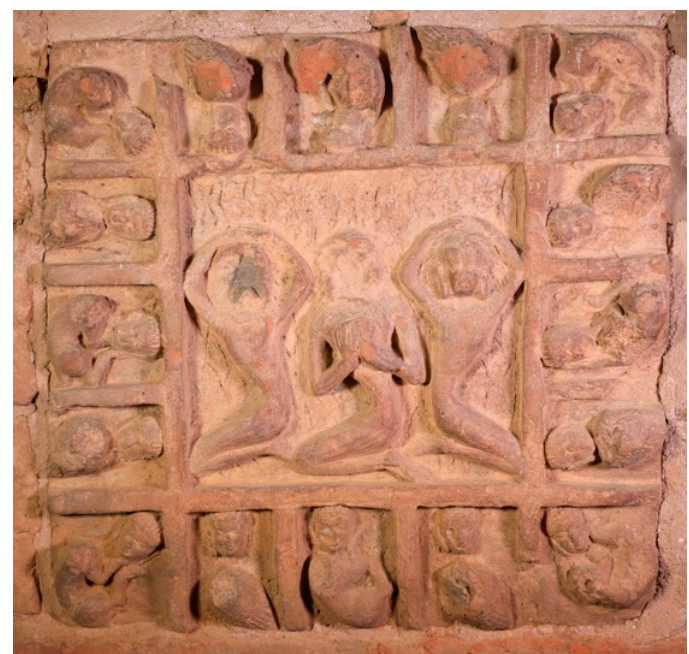

(a)

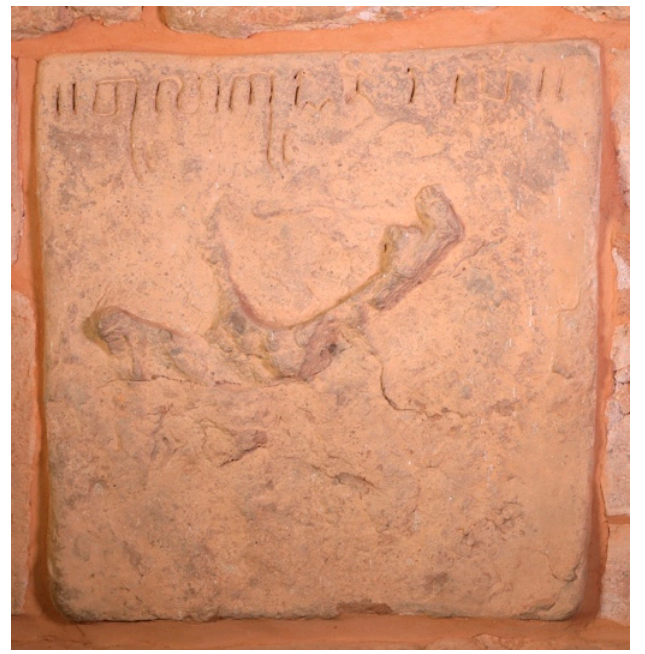

(b)

Figure 38. Pagan, Hpetleik Stupa, 11th century. Two hell plaques—one uninscribed, humans protecting their heads, surrounded by tied up bodies awaiting their turn. The second image is badly damaged but reads Tulakutanirayam (false weight hell). (a) subtitle, (b) subtitle.

60 The structure was found much damaged, and the archaeological department reconstruction record does not reveal where the plaques might originally have been situated. Perhaps the restorers were right to assume that they preceded the plaques narrating the bodhisatta lives, and were placed either in the lowest tiers of the stupa's outer side, or close to the main entrance. See (Luce 1959, p. I: 262-67). 
Such instantiation of horrific punishments was sanctioned by the highest authority; in the Anguttara Nikāya, the Buddha was quoted approving public executions because they scared bystanders into probity ${ }^{61}$ The shock value of an encounter eliciting dread was often underscored, as, for example, when, as a story in the Dhammapada commentary XI.2, relates, the Buddha ordered the display of the decaying corpse of the courtesan Sirima, thereby curing a lovesick monk, but also reminding people of what they preferred to forget, a form of visual narcotic. Placing hell plaques near a stupa's entrance, serving, as it were, as an introduction to the other narratives, did likewise.

About 20 such plaques, illustrating horrific punishments, are still extant, showing ferocious dogs feasting on dead people, women being punished, bodies shoved into cauldrons and one plaque whose image has disappeared but the surviving inscription proclaims 'this is the false weight hell' "tulakutanirayam". These images are the earliest of their kind to survive. Many of their components would have a long shelf life in Burmese art and ideational history.

The hell theme was also often featured in the context of narratives of the Buddha's earlier lives, incorporating theaters of punishment. Most often the story's complexity reduced its content to a simplified format, because monoscenic interpretations encouraged the omission of the "hell" part of the narrative. This was the case, for example, in the Kämavilāpa Jātaka (297), sometimes referenced in the Pagan context as Kamatappatu, showing the wages of lust. (Figure 39a,b).

In the Matakabhatta story, (Jātaka 18) fear of hell was presented as a way of discouraging killing animals for the sacrifice, (Figure 40) as was the case in the Bilārikosiya Jātaka (450) where the god Indra convinces a stingy merchant to give alms by having him told that bad deeds lead to hell. In the Nārada Jätaka (544), the king's daughter Rujā lectures her father on hell as the punishment for bad deeds.

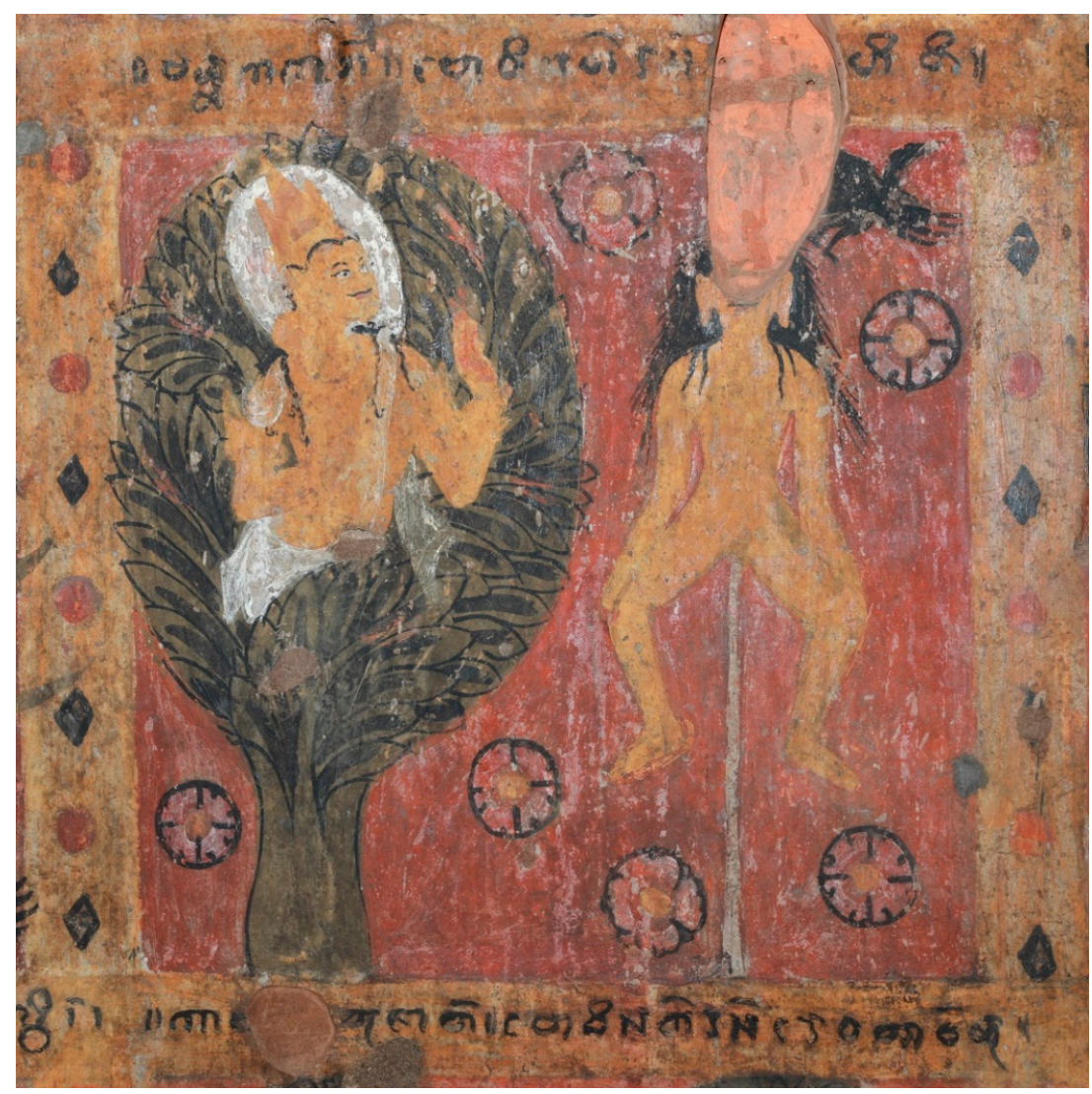

(a)

Figure 39. Cont. 


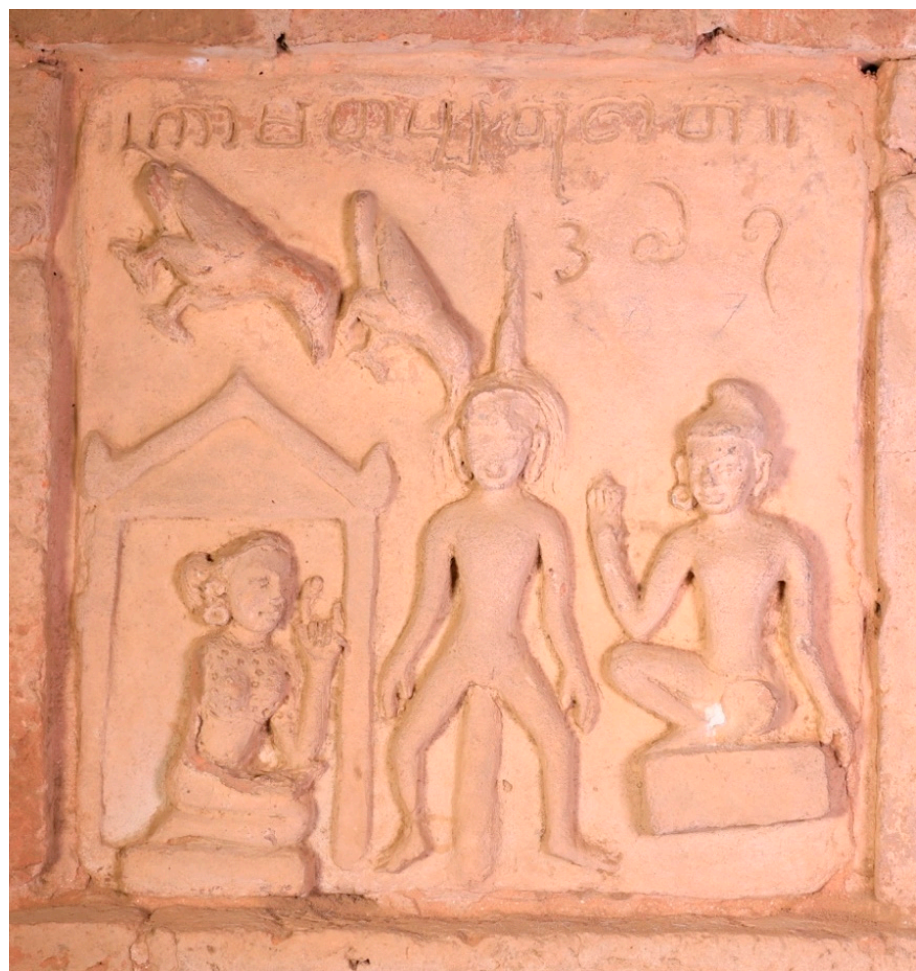

(b)

Figure 39. (a) Pagan, Myinkaba Kubyaukgyi, 1112 AD Kāmavilāpa Jātaka, 297. (b) Pagan, Hpetleik Stupa, 11th century. Kāmavilāpa Jātaka, 297.

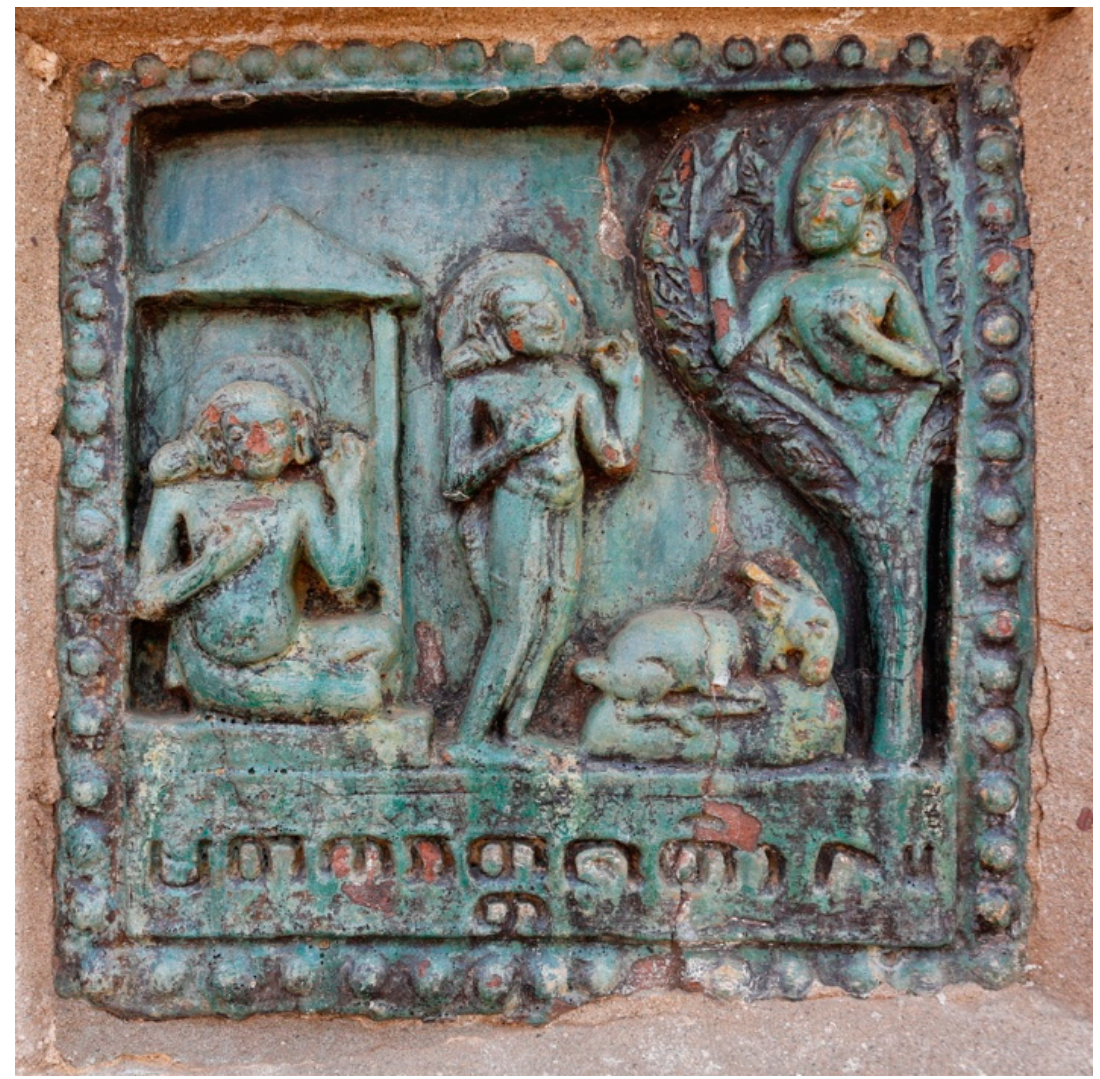

Figure 40. Pagan, Ananda, 11th century. Matakabhatta Jātaka, 18. 
Some visual interpretations clearly meant viewers to experience a samvega moment, as in the case of Mittavinda, whose story is Jātaka 104 and its several variants. Having struck his mother, Mittavinda eventually reaps his punishment in hell, where he had to support a sharply bladed swivel on his head. The depictions often focused on the horrific wheel cutting into Mittavinda's skull. (Figure 41a-c).

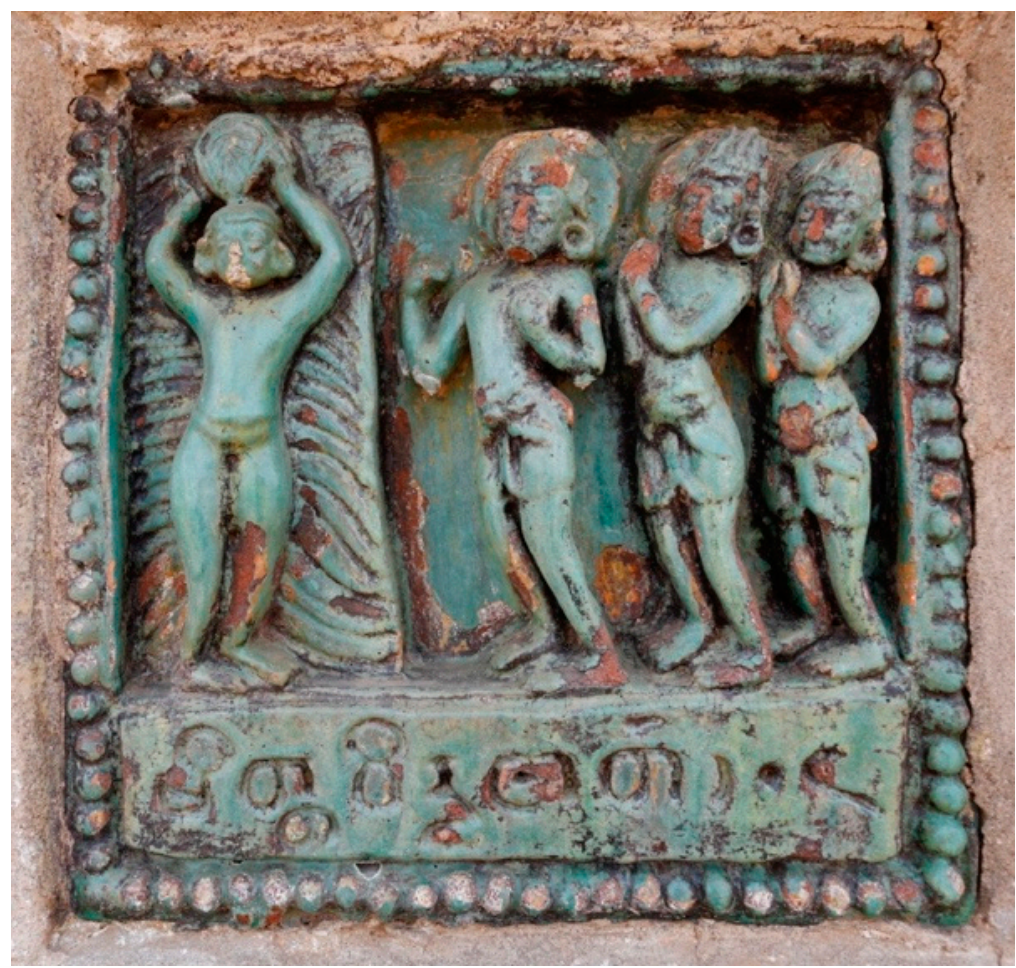

(a)

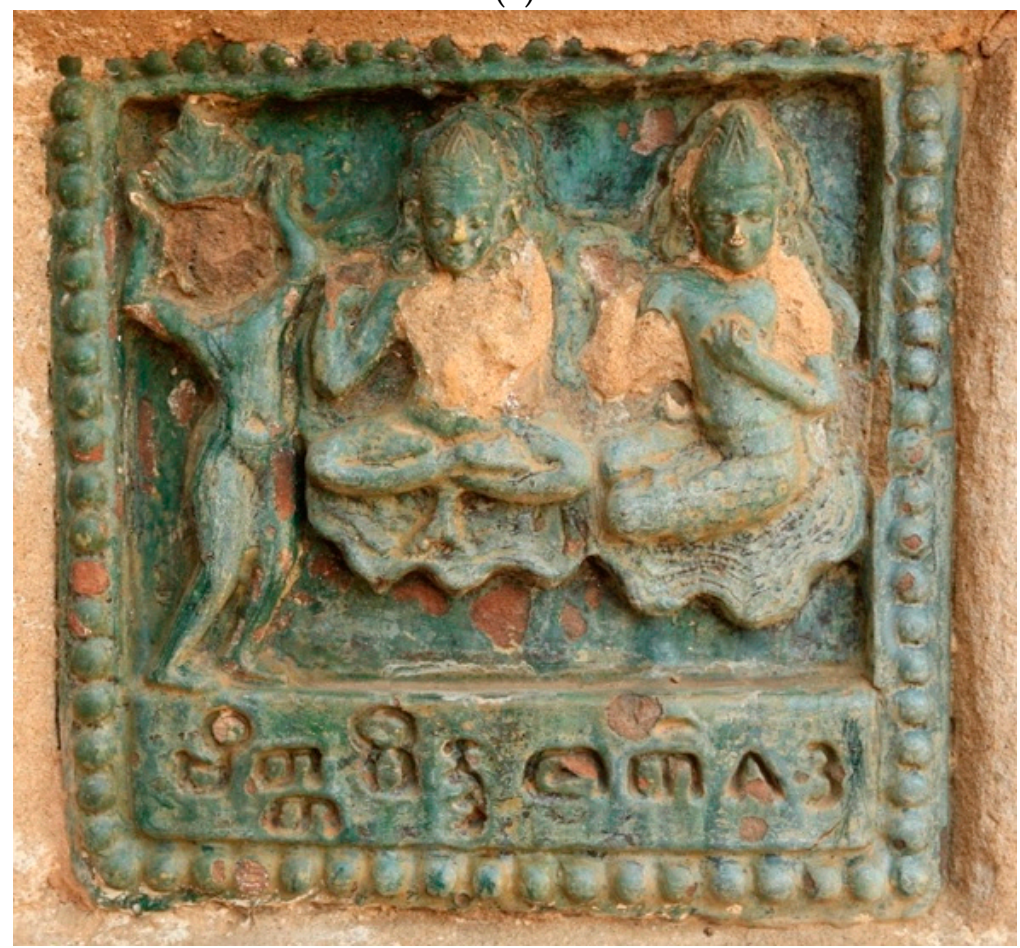

(b)

Figure 41. Cont. 


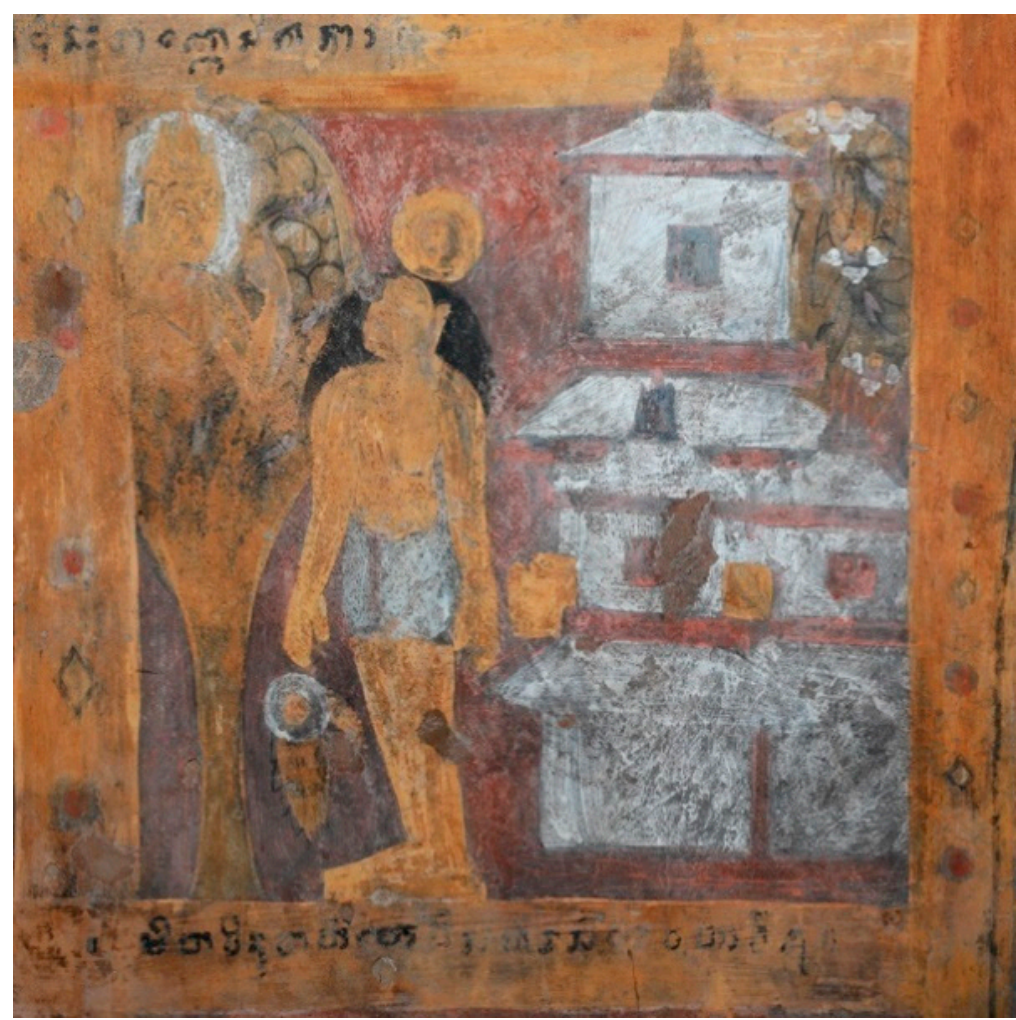

(c)

Figure 41. (a) Pagan, Ananda, 11th century. Mittavinda. (b) Pagan, Ananda, 11th century Mittavinda. (c) Pagan, Myinkba Kubyaugyi 1112 AD Mittavinda.

That was also the case in the Candakumāra Jātaka (Khandahāla Jātaka 542) that highlighted uses of fear by showing beings scheduled for execution, their fate decided by the bodhisatta, who frightened the king into abandoning his mistaken ideas and thus prevented the mass sacrifice. In the Lohakumbhi Jātaka, 314, king Pasenadi hears the cries of the denizens of hell and is terrified. He consults the Brahmins, who tell him to sacrifice living beings. Persuaded by his wife to consult the Buddha, the king listens to the Buddha's account of other frightened kings, conquers his terror and releases the victims. The terror of Lohakhumbi hell, a samvega moment much like Ajātasattu's, was difficult to illustrate. Instead of focusing on Lohakhumbi, the monoscenic take's designers focused on "the remedy", the antidote available in the Dhamma, alluded to by the flower in the image's center, and thus a hint at what pasāda availed. (Figure 42). 


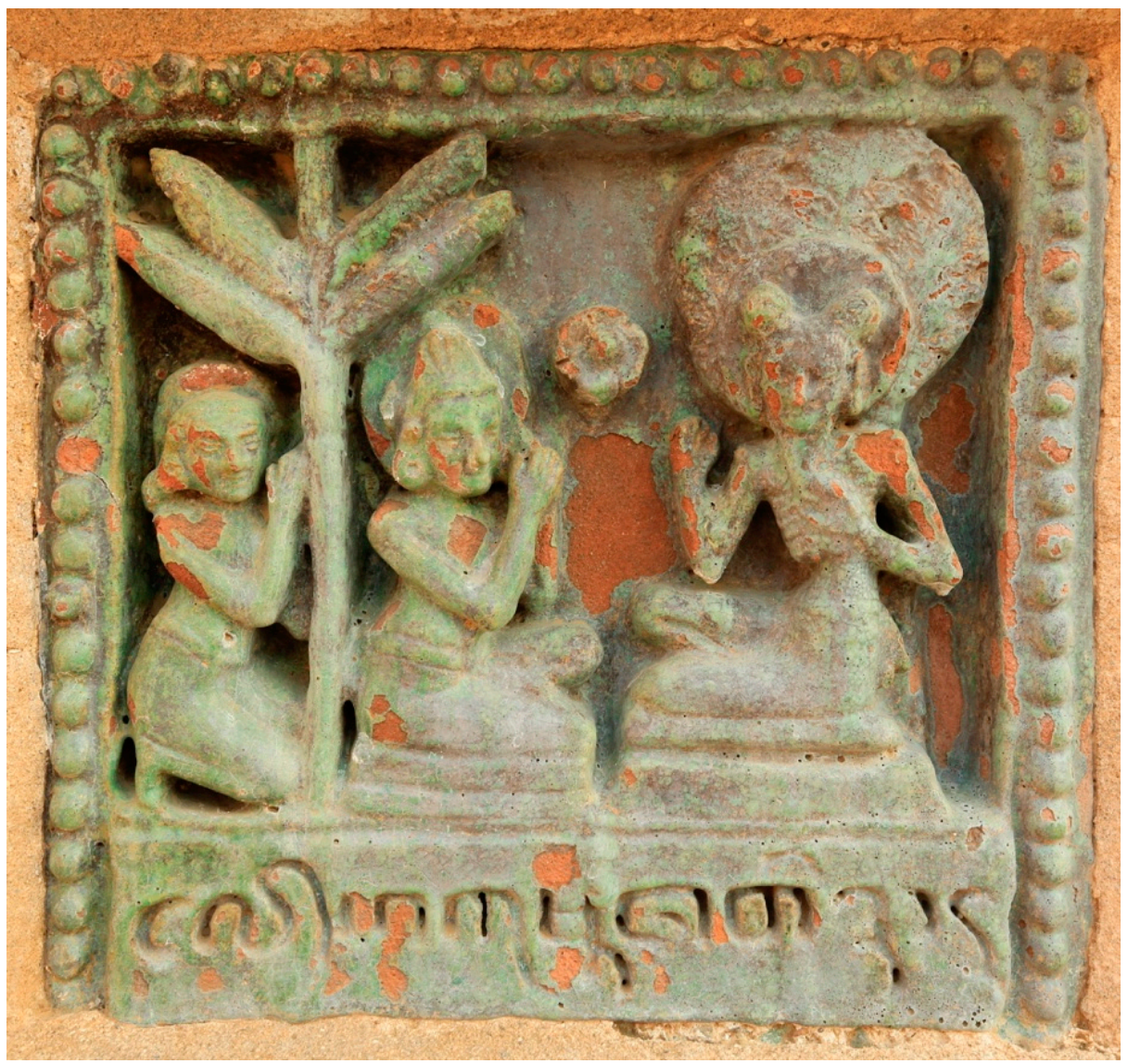

Figure 42. Pagan, Ananda, 11th century. Lohakhumbi Jātaka, 314.

\section{The Dhamma as a Societal Ideology}

This article has argued that images presenting future punishments or rewards were part of a sophisticated conditioning mechanism whereby the Teaching was also a societal ideology explicating the here and the hereafter. If that were indeed the case, the next question is whether there is sufficient indication of such concepts' purchase in the lives of contemporaries. Some evidence suggests that the answer is yes.

Two indications attest to these concepts' resonance, curses by which donors hoped to safeguard their endowments in perpetuity, and, more revealingly, royal proclamations, likely composed by court officials and perhaps leading monks, outlining a royal vision for the realm. Donative documents and royal proclamations etched in stone ensured their survival for later generations. Both instantiated the present's effort to surmount impermanence and to control the future, either so that later generations sustained donors' wishes, or else as reminders of what, officially, this society was about. The latter is particularly astonishing given life's realia during the early centuries, when direct contact between the court and its officials and villagers clustered in small settlements scattered over a big realm was likely nil. Nonetheless, kings, at least notionally concerned for their subjects' wellbeing, also wanted to publicize their status as worthy custodians of the Buddha's teaching and it is these documents that provide a glimpse of what happened when the dhamma was interpreted as the taya to service also mundane needs. Notions of hells featured in donative inscriptions as they did in royal proclamations that also recalled the heavenly realms.

Since the 11th century, donors threatened violators of their stipulations with horrific punishments. The most consequential curse was: "May the evildoer never encounter Metteyya", when nirvāna's attainment was believed to be a realistic expectation, and luxurious lives for a very long time would be enjoyed meanwhile. For those curious about what this meant, there was the Anāgatavamsa, a Pali text 
about the future, one of whose versions was partially inscribed on a mid-13th century endowment's vestibule walls-the Thambula. ${ }^{62}$

For donors, however, denying malefactors' encounters with Metteyya was a problematic threat, given that 10 million years needed to pass before his coming. Scoundrels were likely undeterred by a punishment so far off. Instead, wrongdoers were threatened with Avīci hell, the destination for the perpetrators of the five grave offenses. References to such transgressions are very rare in Pagan records, but from the 13th century onwards, Avīci as a destination features in more prosaic contexts, showing considerable formulaic creativity. ${ }^{63}$

A 13th-century donor hoped violators of his good deed would be cooked in Avīci for as many times as there were particles of earth, and from there they would be moved to the eight great hells, then to 16 smaller hells, transiting from hell to ghost land, from ghost land to hell without returning to the human abode, to suffer untold misery. ${ }^{64}$ By the 18th century, a donor wished malefactors seriatim sojourns in the eight major hells, then in 128 minor ones, the latter multiplying into as many "as there are grains of sand in the Ganges". The offender was also cursed not to meet Metteyya's 8000 successors. ${ }^{65}$

Royal proclamations attesting to hells' usages survive from three reigns, indicating how cosmographic ideas informed aspirations for behavior modification. The 11th-century Kyanzittha, the 13th-century Klacwa, and later the 17th-century Thalun, shared a similar, Dhamma-informed vocabulary. Their sensibilities may have differed, as they presided over different political entities and populations, since the country's borders remained unstable and royal entanglement in matters of morality, local behavior, and control was always a work in progress. Like another early Pagan monarch, the 12th-century Alaungsithu, the three regarded themselves, at the very least, as the Buddha's helpers, ideally facilitating their subjects' release from samsāra, the raison d'etre as Alaungsithu implied, for kingship. The socializing techniques prevailing in their day, were grounded in a similar carrot and stick system.

Kyanzittha (reigned 1084-1112) articulated an astonishingly utopian vision of a just society presided over a by a king who was the recipient of a personal Buddha prophecy. He thereby could promise his subjects accessible heavenly abodes, outlining the road there. ${ }^{66}$ The itinerary, not surprisingly, was the conditioning mechanism in action: a just society was hierarchical, people knowing their places and obligations, fulfilling caste and familial duties and remaining appropriately subordinate, like wives to their husbands. The king was a great believer in an 11th-century version of positive psychology; two entrance alcoves in an endowment dedicated to Kyanzittha by Rajakumar, his son, completed by 1112 AD, featured Vimāna stories, which also appeared in other tiers, while the subject of hells was relegated to the jātakas. Kyanzittha valorized the good people and promised happy afterlives as well as happy current ones.

Kyanzittha, who appropriated several of the Tathāgata's titles, described his interaction with his subjects in similar terms. The Buddha's and the king's solicitude was said to resemble that of a mother cradling her infant, the king even "wiping the nasal mucus of all who are sick at heart". This elusive phrase recognized the grimness of the human condition but also alternatives, given the king's role as consoler in chief. The self-serving call for sustaining "saddhā", that is, confidence in royal messages backed by the Buddha's teachings, draped the king's promises with incontrovertible veracity and authority. ${ }^{67}$ The term saddhā entered the vernacular as a Pali loan, suggesting that what has been

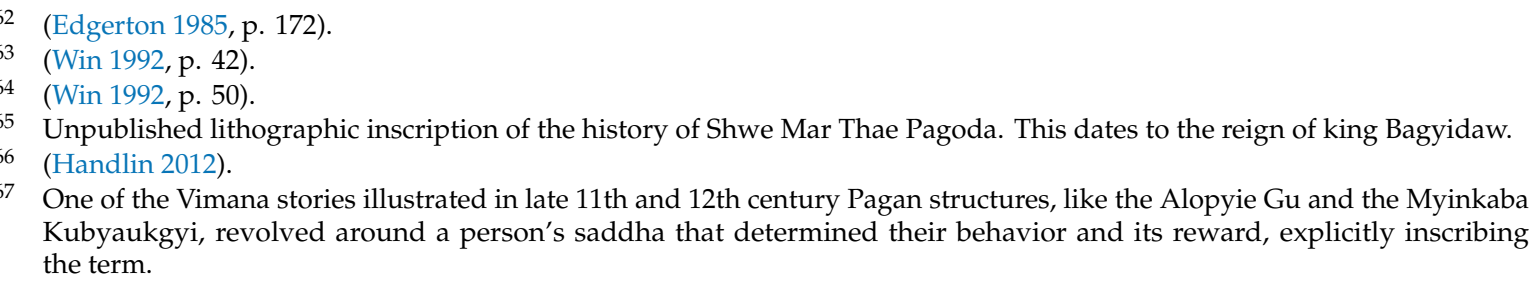


called religion in other settings was here a comprehensive explanation for the human condition with guidelines on how to make the best of it. Saddhā was another pillar of the conditioning process, closely linked to hirī and ottappa and informed by other emotions determining good people's response to life's challenges. For good measure, saddhā's practitioners were shown in their Vimānas. Kyanzittha, therefore, was able to promise his wards happiness "in this world and beyond". ${ }^{6}$

What happiness meant was left conveniently vague, but at the very least it suggested the opposite of suffering. This would have been an astonishing bit of news for those who took this seriously, because it conflicted with real life and how the human was conceived. In dogmatic terms, the eye was but one bodily orifice discharging disgusting trickles, in a body constructed of over 300 bones, 180 joints, bound by 900 sinews, plastered over with 900 pieces of flesh, enveloped in layers of oozing skins, their 99,000 pores seeping sweat good for attracting black flies. This was a fitting description of a being emerging into this world resembling "a worm in rotting fish, in cesspool ... born in between the receptacle for undigested food and the receptacle for digested food...in a place that is stinking, disgusting, repulsive ... " In a world where the Four Truth's bleak outlook reduced life to "birth, death, sickness, fear, grief, and weakness", the human condition was essentialized to encompass 96 diseases, 32 causes of evil, and 25 calamities. The king's proclamation suggested otherwise. ${ }^{69}$

To imply that suffering need not be humanity's lot indicated that, if lives were bad, the causes were maladjustments, improper behavior, or other matters within human purview, since misery was not an unassailable given. In a setting where the notion that there was no such thing as undeserved suffering, this surely was good to know, all the more so in that the king promised to improve the human condition in the here and now. The proclamations' soaring ambitions thereby show how, in the late 11th century, Buddha's teaching were at least partially reformatted, to embody social virtues by reinterpreting their dogmatic content.

A different slant on Dhamma's uses appears 200 years later in the reign of king Klacwa (1234-1249), whose regime experienced serious disarrays, the chroniclers' explanation for the king's inability to complete his most important endowment, the Pyatthada. His travails notwithstanding, however, or perhaps as compensation, Klacwa exceeded his predecessors' aspirations and styled himself as a living Buddha. What this meant in the Burmese context nobody knows. Even the 12th-century Alaungsithu only aspired to become a Buddha in the future, not claiming to be one already. What this meant in actuality for Klacwa's kingdom also remains unclear. Unlike Kyanzittha, Klacwa was not a utopian, and his proclamations assume a permanently grim human condition. One result of his grandiose title and of relevance to this article was a royal concern about the penal code and how it related to the "good people". To align his society more with the Dhamma of which he was custodian and enforcer, perhaps even chief interpreter, Klacwa embarked on reforming punishments, to attenuate prevailing brutality. Whether his proposals succeeded is unclear, but copies of the proposed reforms were to be set up (in the form of stone inscriptions) in the country's larger villages, suggesting the importance the king attached to this proposal and how, in the 13th century, the crown made its wishes known beyond the capital's confines.

Like Kyanzittha, Klacwa informed his subjects that "there is no one equal to me being endowed with strong virtue", also echoing his predecessor by saying that he "had compassion for all the people both lay and monastic, as though they were children of his bosom". This indicates that such phraseology had become a staple of written royal selfies and suggests that saving them from going to hell was a desideratum. The reforms highlighted the gruesomeness of punishments, implying the merciful nature of the king cum Buddha endeavoring to spare his subjects unnecessary pain, but also royal efforts to generate greater uniformity, meant to provide coherence not sought by earlier kings. The pornography of pain as an arm of governance bothered Klacwa sufficiently to suggest amelioration

68 (Handlin 2012; Win 1992, pp. 84-85).

69 (Nanamoli 1999, p. XIX: 4; Gardiner 2012, pp. 9, 19; Eckel 2008). Such calamities lists also featured on donative inscriptions, for example in the unpublished stone inscription of the Shwe Ma Thaw Pagoda. 
but not enough to eschew the uses of fear. Potential malefactors were reminded that punishments in this world were but a prelude to what happened next, the former being nothing compared to Tapano hell where "the whole body, inside and outside, is burned all day and night without intermission for 100,000 years which is the equivalent of ten million years of our human world". The only thing going for villains was earthly lives' brevity that restricted time earmarked for being maimed, tortured, impaled and dismembered. Klacwa also singled out the "good persons" for praise. In the coming centuries such people's eminence soared; by the 18th century, those who disrespected them were said to go to hell. ${ }^{70}$

A more foregrounded textuality informed Klacwa's edict, drawing upon the Majjhima and Anguttara Nikāyas and the Milinda pañha, showing thereby how the Buddhavaccana sustained the prevailing political lexicon. That the proclamation's actual author was "the most excellent and omniscient Lord", justified, Klacwa implied, his demand for "respect, belief and attentiveness", urging on his subjects the also formulaic Pali "doubt not", found in earlier royal pronouncements, to sustain confidence in the Buddha's teachings, in this case transferred to the king. The Maung yon gu endowment, dated to 1273, perhaps in response to these mid-century manipulations, incorporated hell punishments in its décor; surviving inscriptions suggesting they targeted violators of the five precepts. How other aspects of societal behavior were handled by the end of the 13th century remains unknown. ${ }^{71}$

\section{The Reconstitution of the Conditioning Mechanism in the Late Premodern Period}

The visual clues and written evidence attesting to the conditioning strategy's operational features, surviving from the Pagan era in structures like Maung Yon Gu, Theinmazi, Hpetleik, and many others, increased in number and scope after the 16th century, a sign of ongoing adjustments. Ethics and moral life remained matters of local concern, guidance, and enforcement, far removed from the distant sovereign's authority as defender of the Buddha's legacy. However, in the latter half of the 16th century, harbingers of something new appear. An expanded list of publicized offenses were, given this article's subjects, the main indicators of change. The latter is also identifiable in the instabilities of the Buddha Gotama biography panoramas, as well as the more elaborate donative inscriptions that sometimes were written on endowment walls. They evince a greater sense of individuality and of self, making them more distinctive, and also incorporated more Pali. Their social and ideational vocabulary was more expansive, listing practices like meditation, for which there is no Pagan record. The donors' effort to tell their contemporaries and future generations what they were up to makes these post mid-16th century statements considerably more informative than their Pagan equivalents. ${ }^{72}$

The decentralized sangha loosely meshed in lineages provided little uniformity in practice and, as monks were the main advisors to donors, the Uddesika Cetiya(s) always reflected local practice. Aside from matters of taxation, military recruitment, and overall maintenance of law and order, enforcement of ethical norms was left to local authorities. However, as subsequent developments showed, royal interventionist ambition also prompted reinterpretations of the Dhamma. Major historical developments that altered ways of being impacted meanings of key terms like samvega.

Conceptions of hell and heavenly abodes moved with the times, when individuals ceased to be mainly members of their small communities and became enmeshed in a realm whose presiding authorities were now more concerned with personal behavior. Such concerns reformulated notions about future lives. Kyanzitha's and Klacwa's successors inherited the conditioning mechanism and its solicitude for "good people" and the Dhamma that explained life's realia. ${ }^{73}$ However, the much bigger investment of Nyaung Yan and Konbaung dynasties in imaging punishments, and an elaboration of

\footnotetext{
(Frasch 1996, pp. 135, 214-16).

(Handlin 2012). Munier Gaillard and Myint Aung p. 331. For broader implications, see (Druzin and Wan 2015).

(Handlin 2017). An early example is the 17 th century Thirimingala.

In the Powin Daung context, the reference appears in the Nimi Jataka. Image badly damaged.
} 
heavenly mansion stories, were responses to unprecedented disarrays and insecurities that impacted how contemporaries viewed their afterlives. Earlier monarchs also condemned adultery or abortion, for example, but their ambitious successors were more interventionist.

At the same time, new segments of the Pali Daw, once invisible in the public square, entered the Buddha story tapestries. On hand were also, by the 18th century, two extensive Burmese narratives of that story, creating a different mosaic, adding new subchapters, concerned, for example, with Gotami, the bhikkhuni sangha, Gotama's father's funeral, Malika's Gift of the Cloth, the Eight Victories, and much else. (Figure 43, Figure 44, Figure 45)

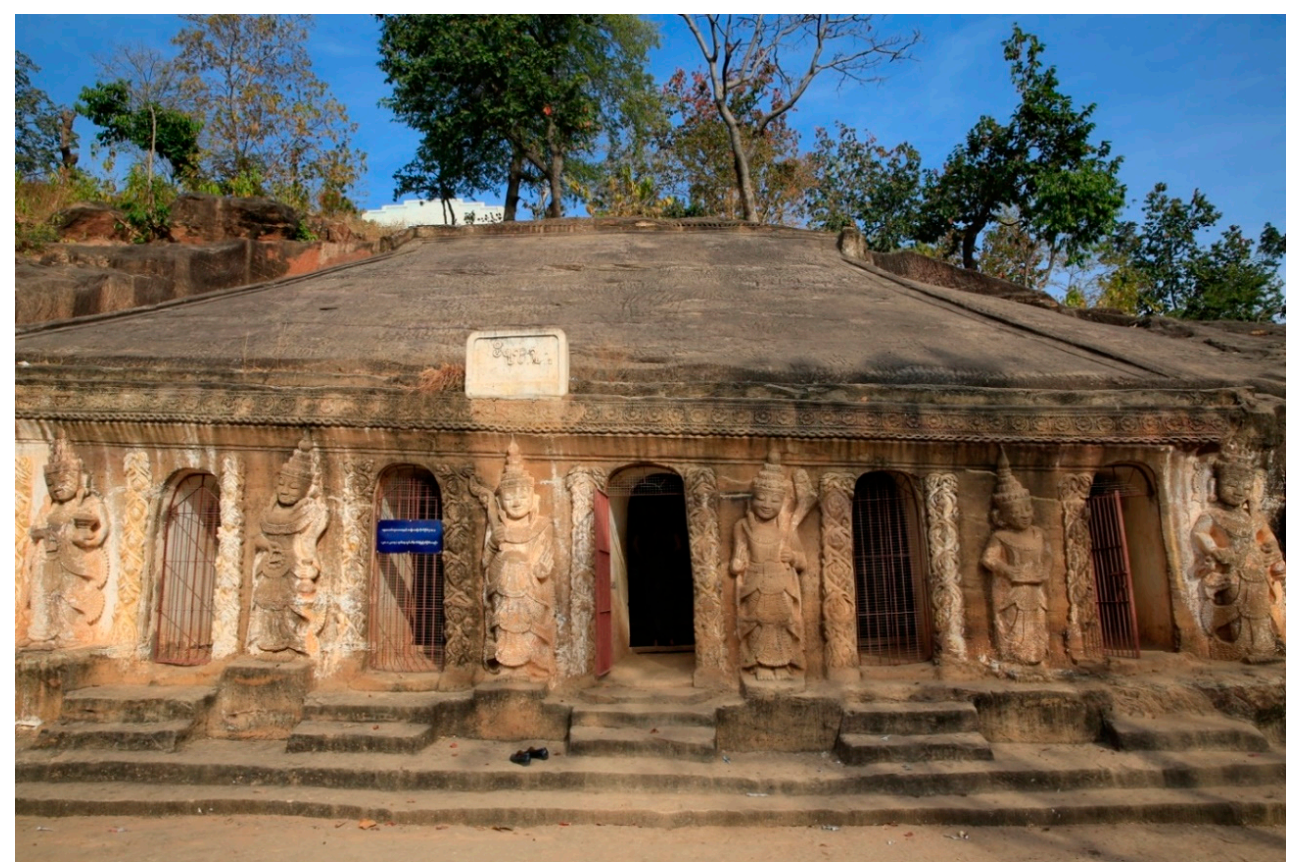

Figure 43. Powin Daung, cave 480 late 18th century. Décor preserving numerous inscribed punishments for specific transgressions.

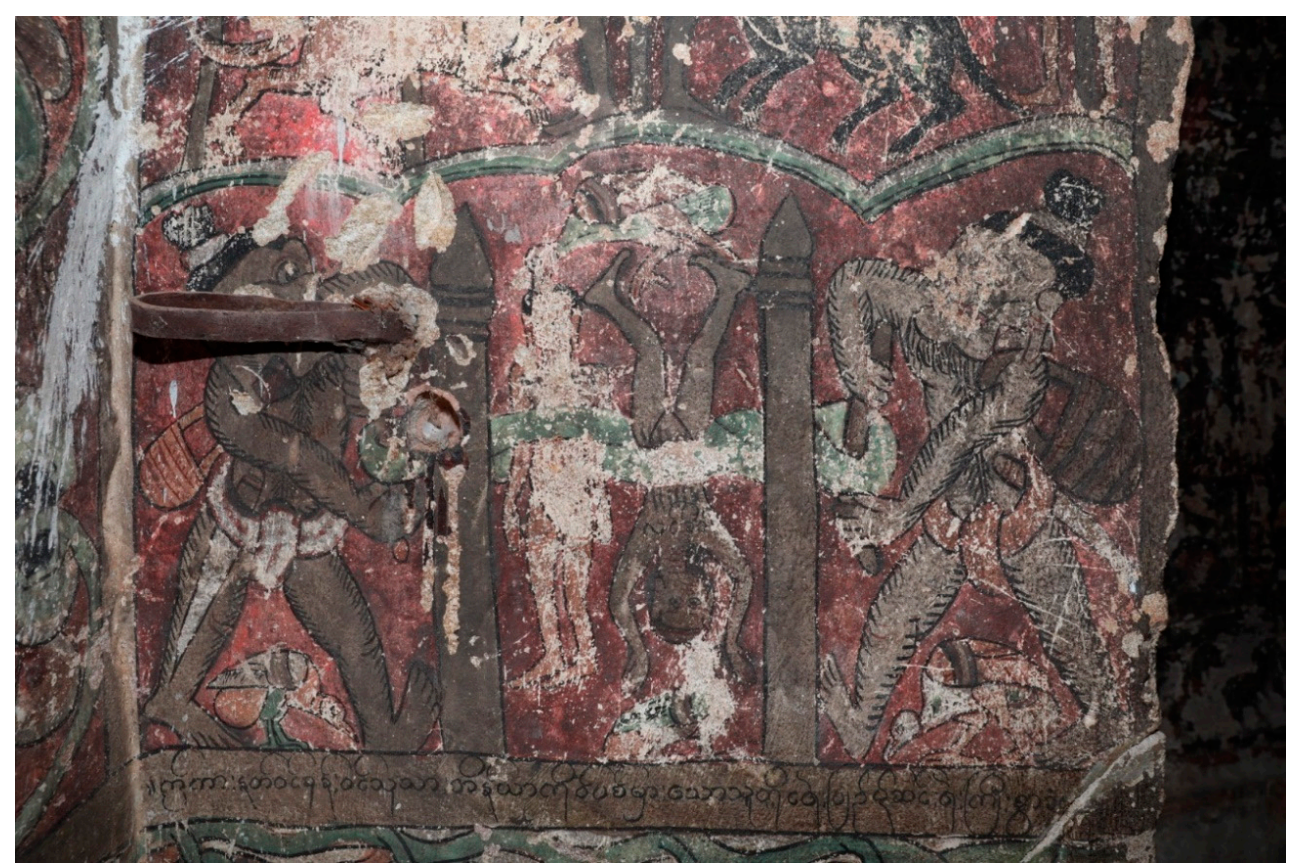

Figure 44. Powin Daung, Cave 480, 18th century. Punishment, among other things, for adultery. 


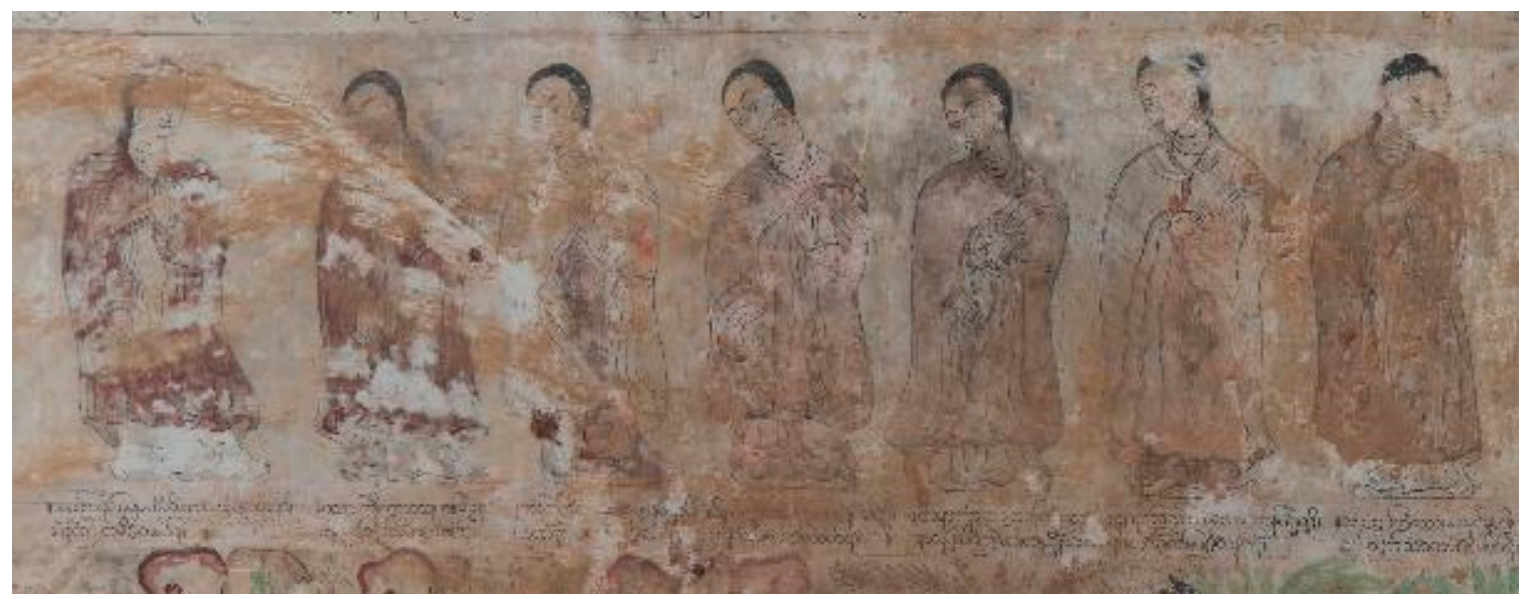

Figure 45. Pagan, Sulamani, images dating to the 18th century. Gotami and the paradigmatic Bhikkhuni(s).

By now, vernacular texts in Thai were also likely known, especially the story of Phra Malai, the Burmese Shin Malae, shown tidying up the Sulamani Cetiya environs in Tāvatimsa, and about to meet Metteyya prior to relating what he learned to the people on earth. More attention also was lavished on differentiating the "good people". Comparing the plaques and paintings of the Pagan era to their counterparts from the 18th and 19th century indicates an altered ideational matrix in which the "deterrence theaters" were embedded. ${ }^{74}$

Foregrounding the criminality of ancient transgressions, once apparently meriting less visibility, sins like animal castration, cheating, making music, lying, taking bribes, gossiping and much more, indicate a new spirit. They were already known from the Nimi Jătaka, but employing animals in agriculture or even hunting and fishing, as well as dishonest dealings, had always been part of daily life. An 18th century version of Pali fundamentalism granted their punishment visibility.

Behind this was a more complex society and economy, the growth of trade, the rise of new classes, higher literacy rates, and exposure to foreign worlds. These significant developments shaped Burma's early encounters with modernity and also impacted how afterlives were conceived. The reason was that such changes unsettled authorized relationships between wealth, social status, and piety, generating a sense that hitherto stable institutions were being undermined. The search for reassurance also informed the interaction between the Buddha's teachings and lay people, generating more textuality and engagement with the Dhamma and even the Abhidhamma. A snake hearing its recitation became an occupant of a heavenly mansion, and a similar experience caused bats to be reborn in Sariputra's entourage. Donative inscriptions, once concise and prosaic, greatly expanded in length and occasionally featured heavy doses of Pali. ${ }^{75}$

A sense of urgency and foreboding was also new, all the more so in that the struggles against encroaching British forces altered the interaction between the crown and its domains when royal policies needed to confront aggressive foreigners. In several endowments, images of the 101 peoples, claimed to make up the country's heterogeneous population were shown revering the Buddha, and thus united also on behalf of the king's earthly allies. Endowments sometimes inserted the list to individualize one of the armies featured in the Mahosadha story. (Figures 46-48).

74 For other settings, see (Merback 1998, p. 21).

75 For comparable developments elsewhere, see (Ebrey and Gregory 1993). Thirimingala inscription, unpublished, is an early example from the 17 th century. 


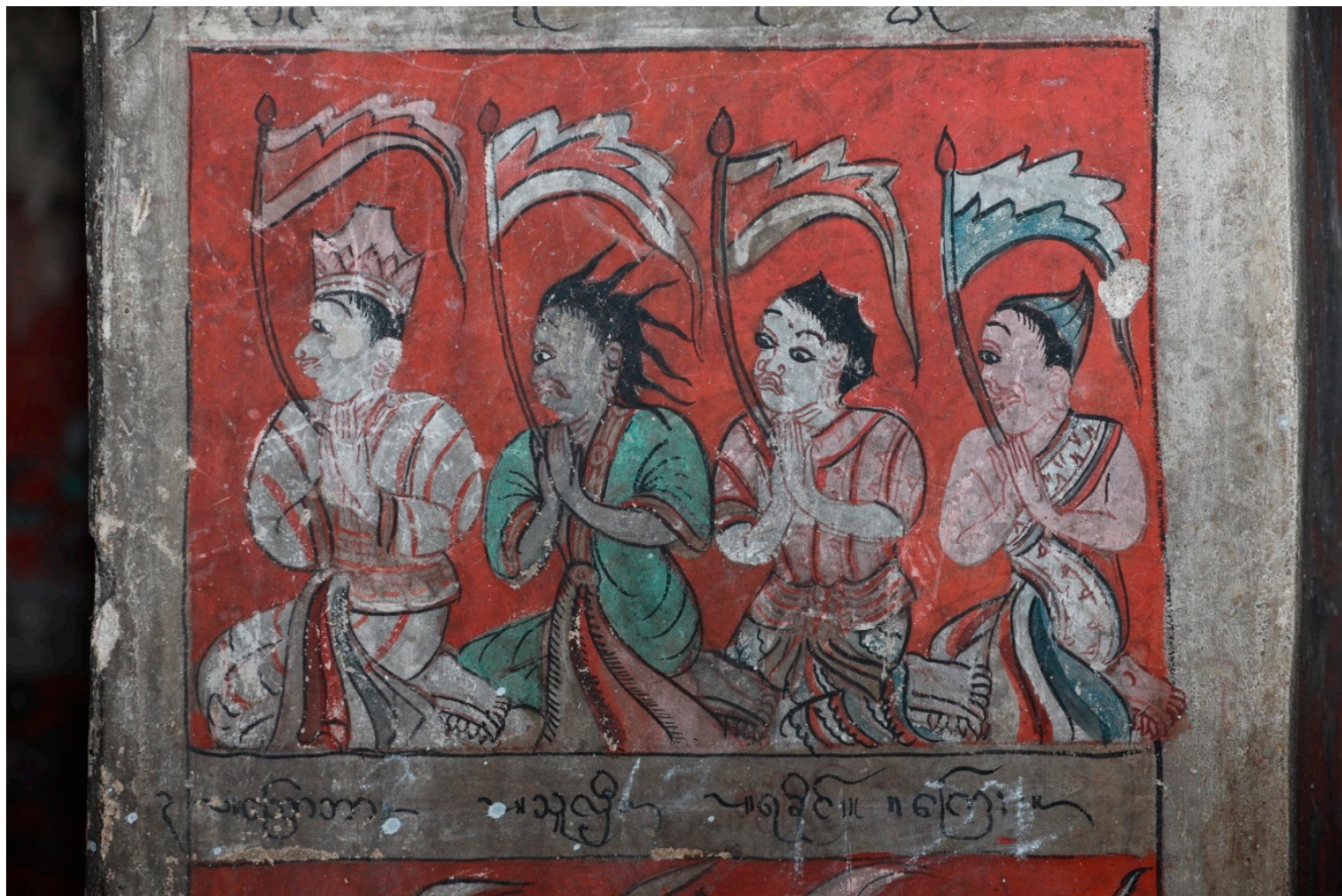

Figure 46. Shin Bin Pwin Lan, 19th century. Four Representatives of Groups among the 101 Tribes, including Rakhine.

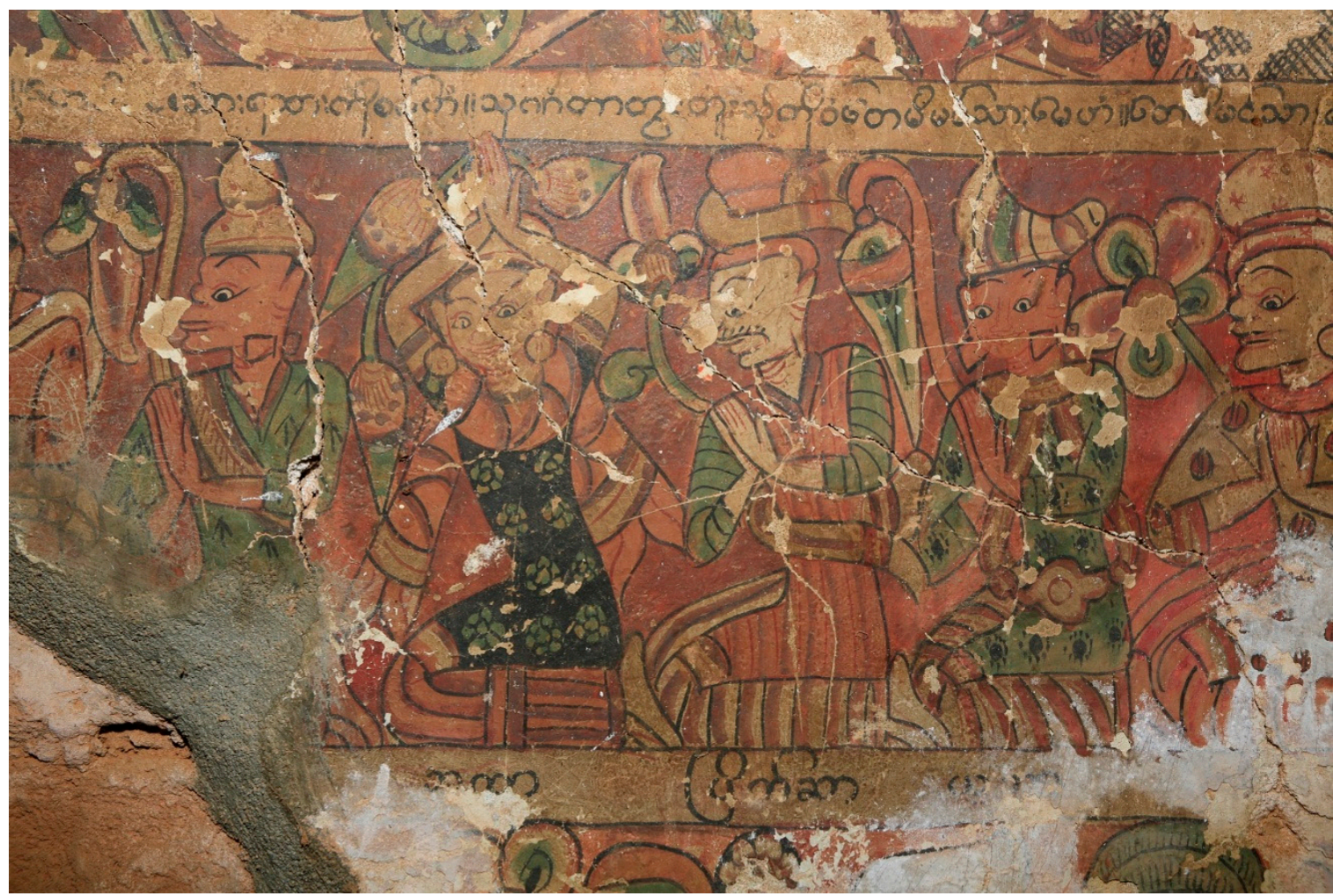

Figure 47. Anaint, 18th century. Five representatives of the 101 Tribes, including a woman. 


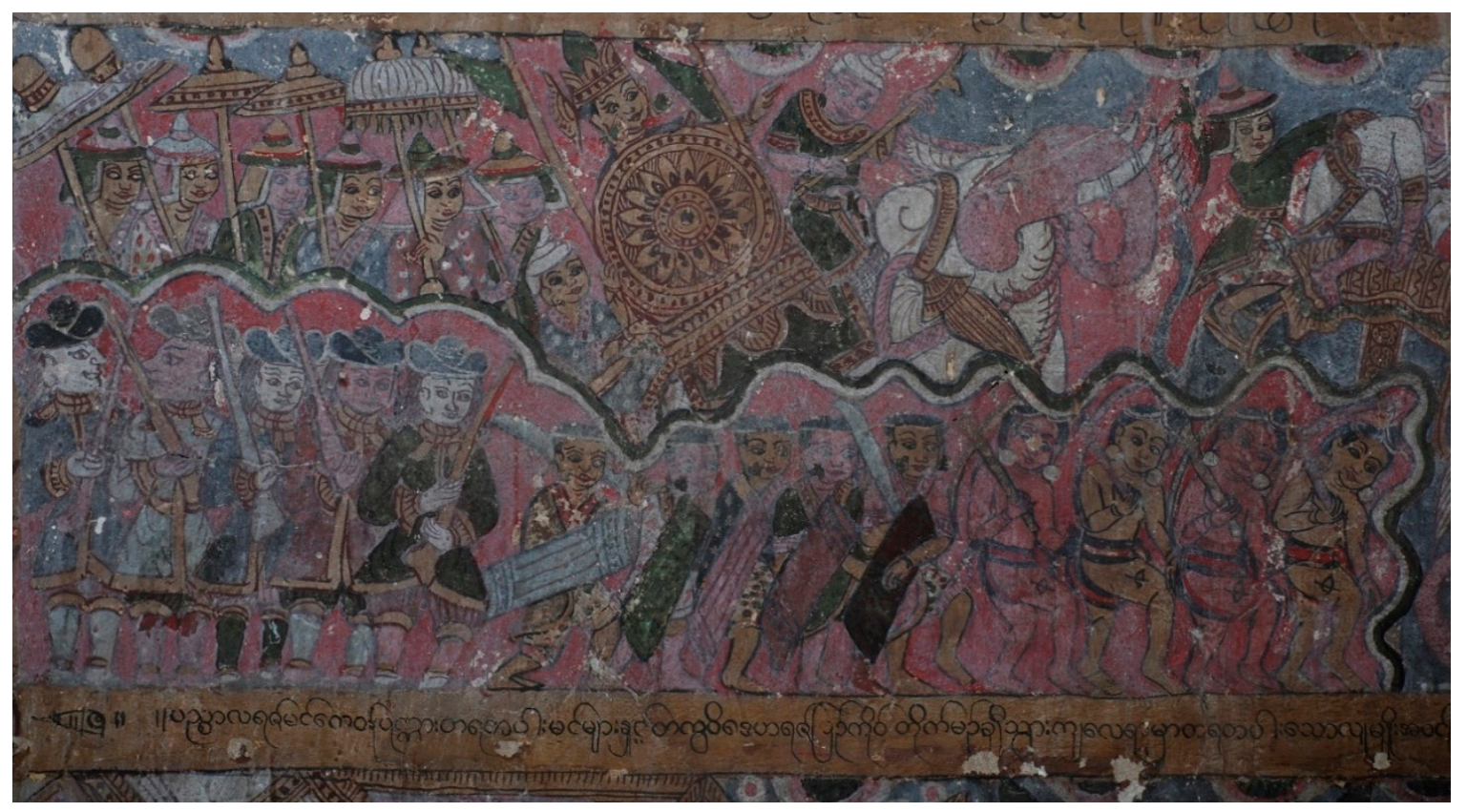

Figure 48. Laung U Maw, Ywathitkye. Early 19th century. Segment of the 101 Tribes, incorporated in the Mahosadha Jātaka.

Administrative changes and such groups' (most of them unidentifiable) allegiance did not thereby displace local control, exercised by land-based grandees authorized to benefit from their domains, nor did they alter social and cultural dynamics. Much like in Pagan, where misleading similarities belied a lack of uniformity, Nyaung Yan and early Konbaung structures likewise reflected the localism of donors, painters, program composers, and perhaps the sangha lineage of the monks affiliated with the compounds' housing such structures. ${ }^{76}$

Village troublemakers, once dismissed as nuisances, were, after the 17th century, threatened with hell, because their antics in more complex settings were a threat. Injunctions against assaults on property and institutions defining the common weal materialized. Disrespecting parents had always met with disapproval, but after the 17th century bulletin boards showed the result, not simply in the context of the Mittavinda Jātaka (104) as before, but as an independent component.

A society evincing problematic inequalities made jealousy of others lead to rebirth in hell. Gamblers, cock fighters, mediums, and animal castrators were singled out, identified sometimes by their special headdresses or else by tortures that turned them into the beings they had once mistreated. This applied to hunters, fishermen, and others. (Figure 49)

A changing visuality was paralleled by early modifications in the connotation of samvega and how hirī and ottappa continued to safeguard what was a different world. The terms survived, but, like old bottles filled with new wine, as contemporaries read different meanings into them. Compared to the earlier sense of what samvega meant in the days of Kyanzittha or Klacwa, later Burmese generations made it more rational, linking samvega less to emotions and more to self-control via the mind. A famous 20th-century commentator parsed Siddhārtha's "penetrative samvega" as a form of reflection and ratiocination, thereby also recasting what the sight of the four omens engendered. The gods, troubled by the prince's high life, aimed to restore his "sense of mindfulness", from which he had been distracted by his father's stratagems. In the new version, pasāda was informed not only by the sight of the recluse, but by a conversation Siddhārtha engaged in with the apparition, regarding the benefits of

76 For background, see (Charney 2006; Lieberman 2016). For analysis of the imagery and its settings from which this article departs in its interpretation, see (Green 2018). 
the ten courses of wholesome actions, renunciation, treating sentient beings well, and working for their welfare. The omens were interpreted to mean that the encounter with old age cured the prince of the hubris typical of the young, the presence of the sick men divesting him of glorying in his own health, the sight of the dead man dissipating the fantasy of living forever. Earlier generations' sense of samvega as a "holy shit moment" survived, but were dressed in a somewhat different garb. As for pasāda, it was now linked to practices such as meditation, another instance of perennial written and visual volatility. ${ }^{77}$

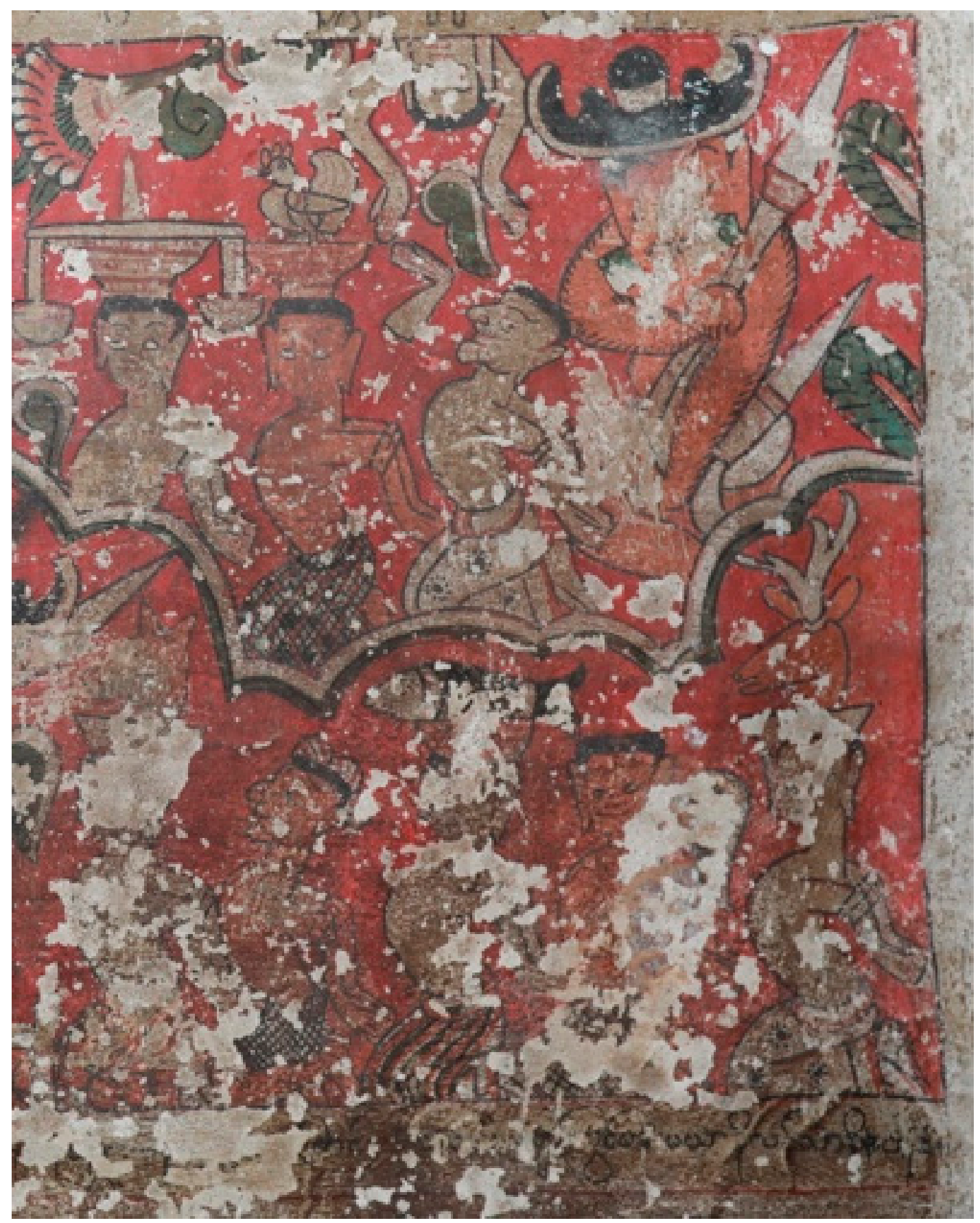

Figure 49. Anaint, 18th century. Punishments for transgressions, including mistreating animals. 
The shift becomes visible in the reign of King Thalun (1584-1648), suggesting sub-currents materializing earlier but difficult to identify. One of Thalun's edicts threatened street pipe smokers with 100-lash strokes, because of fires that plagued crowded settlements, indicating more invasive royal authority as well as the growth of population centers. Corrupt tax collectors were probably always subject to horrific punishments; now, they were threatened with dismemberment in the market square, the impaled having their bodily remains devoured by birds and beasts. Lawyers, (what the sense of that term meant in this context remains unknown), were singled out, and a few decades later shown meriting a peculiar punishment, altering their private parts to become giant, slimy and foul-smelling testicles. (Figures 50 and 51).

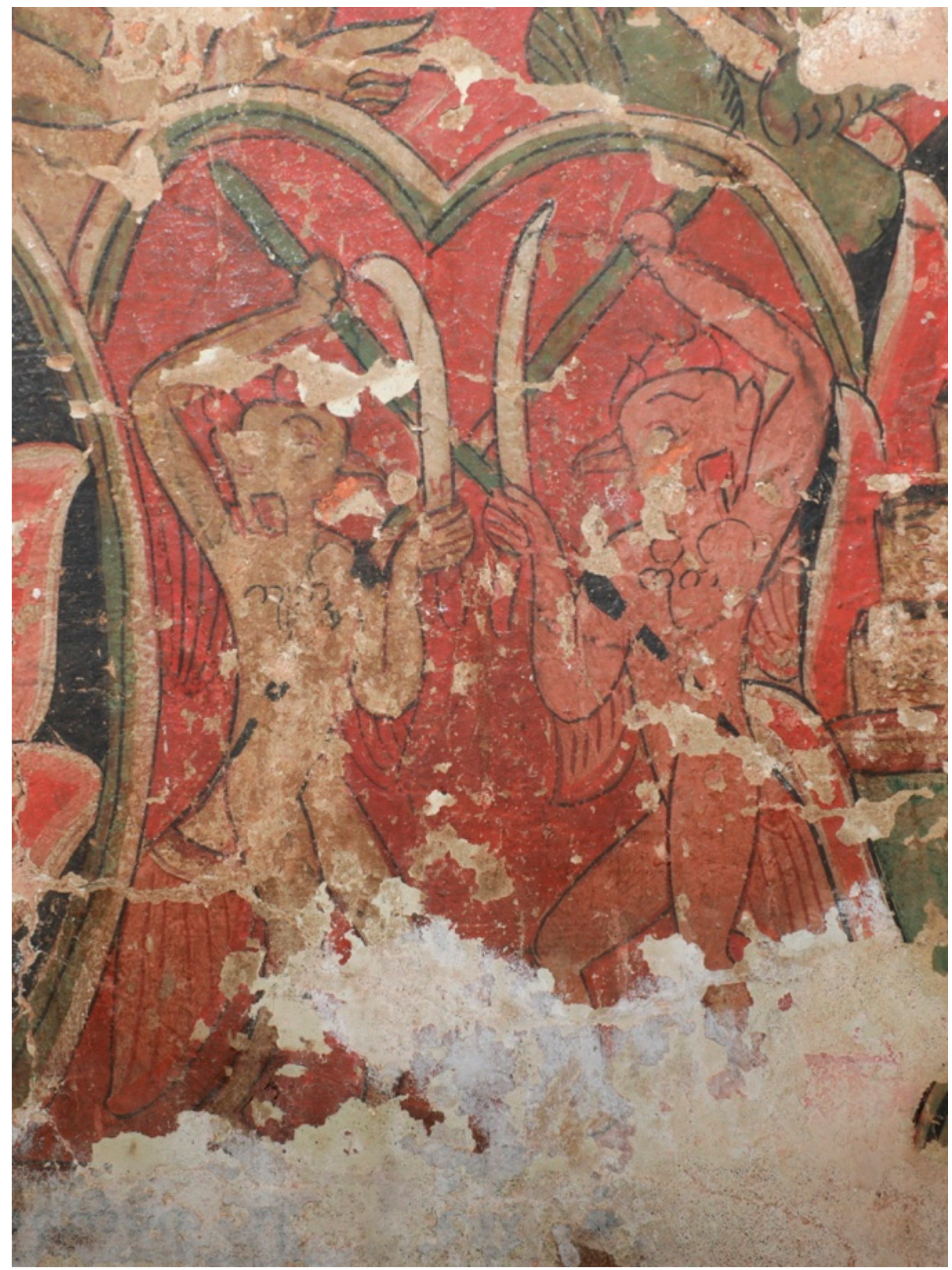

Figure 50. Anaint, 18th century, Punishment for Engaging in Cock Fights. 


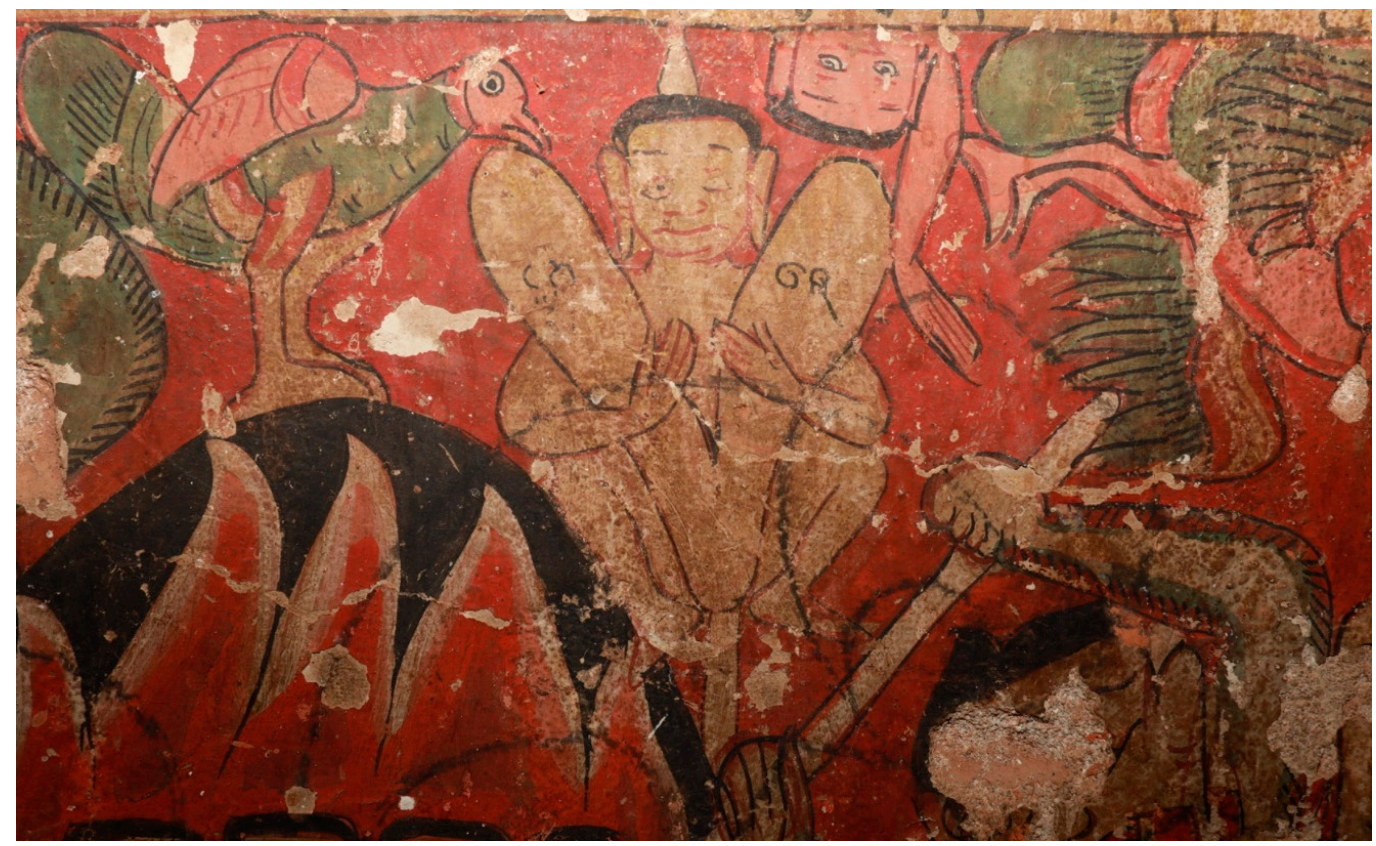

Figure 51. Anaint, Endowment 69, 18th century. Punishment for pleaders.

In this new world, ordinary and extraordinary vices were divested of their narrative contexts, and highlighted independently, targeting mediums, drunkards, vendors of intoxicants, and people who lied or hoped to attain their goals by dishonesty or flattery. None of the above means to suggest that a much better integration of authority and control had materialized by the time of king Thalun's reign, but his ambition augured transformations. A wishing tree, inserted as a break between narratives linked to the Buddhavamsa, Vessantara, Vidhura and Nimi Jātaka, slivers above inscribed hell scenes, providing the counterfoil. ${ }^{78}$

It is unclear why this profound shift, individualizing offenders, materialized at this point. In Sri Lanka and Thailand, wrongdoings merited a vernacular literature earlier and followed different timelines, realigning current events and concerns about the future. In Burma, this development dovetailed with the visibility of a more invasive authoritarian spirit prioritizing greater self-discipline, proscribing stealing other men's wives, but also being a party animal. A harbinger of the times was an expanding bureaucracy; in this world the king, who, in the next Yama acquired assistants, bookkeepers and what we would call pencil pushers in addition to the ancient helpers shoving human bodies into cauldrons. ${ }^{79}$

\section{Conclusions}

Dhammadinna, whom we have met with his magic fan, also appears in the Visuddhimagga to help his teacher become an arahat. He does this by frightening him with a mere apparition of a charging elephant. The teacher's scare signals inadequacy, because a truly awakened being would have realized the elephant's illusory nature. The evoked terror serves its purpose as the teacher asks for help that Dhammadinna provides, opening the path to making him an arahat. In a world plagued by what Buddhaghosa called "Mara's bait(s)", hell images were warnings to those incautious enough to swallow them. By the 18th century, such admonitions were more in demand. Hirī and ottappa

78 For comparable developments elsewhere, see (Roodenburg and Spierenburg 2004). See also for Thai context that by then would have begun to be influential in the Burmese setting (Brereton 1995). For similar components in other circulating texts, see (Hazelwood 1983, pp. 42, 194). Also (Hazelwood 1987, pp. 23, 41, 35, 222). For translation of captions under the Powin Daung cave images, see (Gaillard Munier 2007, p. 331).

79 See (Horner 1966). 
were as always on hand, the difference between them was illustrated by Buddhaghosa's metaphor of the iron rod, smeared at one end with feces, the other red hot. Hirī was like disgust at touching the excrement, ottappa like the fear of touching the latter. For the good people, they were two of the seven kinds of supports that acted like a powerfully guarded fortress, its pillar saddhā, its moat hirī and ottappa. They were thereby freed of the 100,000 kinds of Maras. What more could one ask for? ${ }^{80}$

Funding: This research received no external funding.

Acknowledgments: The author thanks Elizabeth Moore and Yin Ker, Ko Than Zaw and Daw Tin Tin Aye, as well as the article's anonymous reviewer, for their helpful comments. She also thanks the editors of this journal issue, Phyllis Granoff and Sonya Rhie Mace for their initial corrections and suggestions that much improved this article's earlier version.

Conflicts of Interest: The author declares no conflict of interest.

\section{References}

\section{Primary Sources}

Anderson, Carol S. 2012. What do We See through the Dhamma Eye. In Embedded Languages: Studies of Sri Lankan and Buddhist Cultures. Edited by Anderson. Colombo: Sri Lanka, Godage International Publishers, pp. 151-92.

Anonymous. 2016. Pathamasambodhi, The Life of the Lord Buddha. Bangkok: Wat Phrachetuphon

Bodhi, Bhikkhu. 1993. Questions of King Milinda: An Abridgement of the Milindapanha. Translated by N. K. G. Mendis. Kandy: Buddhist Publication Society.

Bodhi, Bhikkhu. 2000. Samyutta Nikaya, the Connected Discourses of the Buddha. 2 vols. Somerville: Wisdom Publications.

Bodhi, Bhikkhu. 2012. Numerical Discourses of the Buddha: A Translation of the Anguttara Nikaya. Somerville: Wisdom Publication.

Bullis, Douglas. 1999. Mahanamasthavira, the Mahavamsa. Fremont: Jain Publishing Co.

Burlingame, Eugene Watson. 1921. Buddhist Legends Translated from the Original Pali Text of the Dhammapada Commentary. 3 vols. Cambridge: Harvard University Press.

Collins, Steven. 1993. The story of the elder Maleyyadeva. Journal of the Pali Text Society 18: 65-77.

Cowell, Edward B. 1994. Jatakas. 6 vols. Delhi: Motilal Banarsidass.

Davids, T. W. Rhys. 1890. Questions of King Milinda. 2 vols. Oxford: Clarendon Press.

De Silva, Padmasiri. 2007. Theoretical perspectives on emotions in early Buddhism. In Jayatilleke Commemoration Lecture, 1976. Colombo: Sri Lanka, n.p.

Hazelwood, Ann Appleby. 1983. Saddhammopayana. Master's thesis, Australian National University, Canberra, Australia.

Hazelwood, Ann Appleby. 1987. Pancagatidipani. Journal of the Pali Text Society 11: 131-58.

Horner, Iseline B. 1963-1964. Milindapanha. 2 vols. London: Luzac.

Jayawickrama, Nidana A. 2000. Story of Gotama Buddha Jataka Nidana. Oxford: Pali Text Society.

Masefield, Peter. 2000. The Itivuttaka. Oxford: Pali Text Society.

Law, Bhimala C. 1923. The Buddhist Conception of Spirits. Calcutta: Thacker, Spin and Co.

Nanamoli, Bhikkhu, and Bhikkhu Bodhi. 1995. Middle Length Discourses of the Buddha: A New Translation of the Majjhima Nikaya. Somerville: Wisdom Publications.

Nanamoli, Bhikkhu. 1999. Visuddhimagga of Buddhaghosa. In The Path of Purification. Seattle: BPS Pariyatti Edition.

Olivelle, Patrick. 2008. Life of the Buddha by Asvaghosa. New York: New York University Press.

Shaw, Sarah. 2006. THE JATAKAS: Birth Stories of the Bodhisatta. London: Penguin.

80 (Nanamoli 1999, I: 22: VII: 59, XXI: 59, XXII: 111-112; Heim 2012, p. 242; Bodhi 2012, pp. 1070, 1230). See also Bhkkhu Bodhi, The Guardians of the World, www.accesstoinsight.org. 
Thanissaro, Bhikkhu. 1997. Affirming the Truths of the Heart: Buddhist Teachings on Samvega and Pasada. Dhammatalks.org. Available online: https://www.dhammatalks.org/books/NobleStrategy/Section0004.html (accessed on 6 May 2020).

Trenckner, Carl Wilhelm, ed. 1880. The Milindapanho, Being Dialogues between King Milinda and the Buddhist Sage Nagasena. London: Williams and Norgate.

Walshe, Maurice, and Venerable Sumedho Thera. 1995. The Long Discourses of the Buddha, a Translation of the Digha Nikaya. Boston: Wisdom Publications.

Wilson, Liz. 1996. Charming Cadavers. Chicago: University of Chicago Press.

Woodward, Frank Lee, and Edward M. Hare. 2008. Book of Gradual Sayings: Anguttara Nikaya, or More-Numbered Suttas. 5 vols. Oxford: Pali Text Society.

\section{Secondary Sources}

Barro, Robert, and Rachel Cleary. 2019. The Wealth of Religions: The Political Economy of Believing and Belonging. Princeton: Princeton University Press.

Blackburn, Anne. 1998. Looking for the Vinaya: Monastic Discipline in the Practical Canon of the Theravada. Journal of the International Association of Buddhist Studies 22: 255-85.

Braarvig, Jens. 2009. The Buddhist hell, an early instance of an idea? Numen 56: 254-81. [CrossRef]

Brereton, Bonnie. 1995. Thai Tellings of Phra Malai: Texts and Rituals Concerning a Popular Buddhist Saint. Tempe: Arizona State University.

Charney, Michael W. 2006. Powerful Learning: Buddhist Literati and the Throne in Burma's Last Dynasty. 1752-1885. Ann Arbor: Centers for South and Southeast Asian Studies, University of Michigan.

Collins, Steven. 1998. Nirvana and Other Buddhist Felicities. Cambridge: Cambridge University Press.

Coomaraswamy, Ananda K. 1943. Samvega, aesthetic shock. Harvard Journal of Asiatic Studies 7: 174-79. [CrossRef]

Crosby, Kate. 2006. A Theravada code of conduct for good Buddhists. Journal of the American Oriental Society 126: 177-87.

De La Perriere, Benedicte Brac. 2009. An overview of the field of religion in Burmese studies. Asian Ethnology 68: 185-210.

De Silva, Padmasiri. 2018. The Psychology of Emotions and Humor in Buddhism. Cham: Palgrave Macmillan.

Druzin, Bryan, and Anthony S. Wan. 2015. The Theatre of Punishment: Case Studies in the Political Function of Corporal and Capital Punishment. Washington University Global Studies Law Review 14: 357-99.

Duggan, Lawrence G. 1989. Was Art Really the Book of the Illiterate? Word and Image 5: 227-51. [CrossRef]

Ebrey, Patricia B., and Peter N. Gregory. 1993. Religion and Society in Tang and Sung China. Honolulu: University of Hawaii Press.

Eckel, David M. 2008. Bhaviveka and His Buddhist Opponents. Cambridge: Harvard University Press.

Edgerton, Samuel Y. 1985. Pictures and Punishment: Art and Criminal Prosecution during the Florentine Renaissance. Ithaca: Cornell University Press.

Foucault, Michel. 2008. Discipline and Punish. Translated by Alan Sheridan. London: Penguin Books.

Frasch, Tilman. 1996. Pagan, Stadt und Staat. Stuttgart: F. Steiner.

Gaillard Munier, Cristophe. 2007. Burmese Buddhist Murals. Epigraphic Corpus of the Powin Taung Caves. Bangkok: White Lotus.

Gaillard Munier, Cristophe. 2019. Depictions of Portuguese in the Buddhist Murals of Myanmar. Orientations 50: 92-102.

Gardiner, Eileen, ed. 2012. Buddhist Hell: Visions, Tours and Descriptions of the Infernal Netherworld. New York: Ithaca Press.

Giustarini, Giuliano. 2012. The role of fear (bhaya) in the Nikayas and the Abhidhamma. Journal of Indian Philosophy 40: 511-31. [CrossRef]

Granoff, Phyllis. 2012. After sinning: some thoughts on remorse, responsibility and the remedies for sin in Indian religious traditions. In Sins and Sinners: Perspectives from Asian Religions. Edited by Phyllis Granoff and Koichi Shinohara. Ldeiden: Brill, pp. 175-215.

Green, Alexandra. 2018. Buddhist Visual Cultures: Rhetoric and Narrative in Late Burmese Wall Paintings. Hong Kong: Hong Kong University Press. 
Hallisey, Charles, and Anne Hansen. 1996. Narrative, sub ethics and the moral life, some evidence from Theravada Buddhism. Journal of Religious Ethics 24: 305-27.

Handlin, Lilian. 2017. Hedging Against Lives Uncertainties and the Theravada Label. Journal of Burmese Studies 21: 97-132. [CrossRef]

Handlin, Lilian. 2012. The King and His Bhagava. In How Theravada Is Theravada: Exploring Buddhist Identities. Edited by Peter Skilling, Jason A. Carbine, Claudio Cicuzza and Santi Pakdeekham. Chiang Mai: Silkworm Books, pp. 165-236.

Harre, Rom, ed. 1998. The Social Construction of Emotion. Oxford: Blackwell.

Harris, Elizabeth J. 1990-1994. Violence and Disruption in Society: A Study of the Early Buddhist Texts. Boston: Wheel Publication, pp. 1-35.

Heim, Maria. 2003. The Aesthetics of Excess. Journal of the American Academy of Religion 71: 531-54. [CrossRef]

Heim, Maria. 2012. Shame and Apprehension: Notes on the Moral Value of Hiri and Ottappa. In Embedded Languages: Studies in Religion, Culture and History of Sri Lanka. Edited by Carol Anderson. Colombo: S. Godage and Brothers, pp. 237-60.

Horner, Iseline B. 1966. Earth as Swallower. Artibus Asiae Supplementum 23: 151-59. [CrossRef]

Jagarabhivamsa, Tipitakadhara. 1986. (1348, Burmese Era). Samvegavatthudipani. Mandalay: Nyunt Sarpay. (In Burmese)

Lieberman, Victory. 2016. Burmese Administrative Cycles: Anarchy and Conquest, 1580-1760. Princeton: Princeton University Press.

Luce, Gordon H. 1959. Old Burma Early Pagan. 3 parts. New York: J. J. Augustine.

MacIntyre, Alasdair. 2002. A Short History of Ethics, 2nd ed. Notre Dame: University of Notre Dame Press.

Malalasekera, Gunapala Piyasena. 1937-1938. Dictionary of Pali Proper Names. 2 vols. London: J. Murray.

Merback, Mitchell B. 1998. The Thief, The Cross and the Wheel: Pain and the Spectacle of Punishment. Chicago: University of Chicago Press.

Mingun, Sayadaw. 2008. Great Chronicles of Buddhas. Singapore: Singapore Edition.

Mrozik, Suzanne. 2012. Astonishment: A Study of an Ethically Valorized Emotion in Buddhist Narrative Literature in Embedded Languages: Studies of Sri Lankan and Buddhist Cultures. Edited by Carol S. Anderson. Colombo: Godage International Publishers Ltd., pp. 261-88.

Nyanaponika, Thera, and Hellmuth Hecker. 1997. The Great Disciples of the Buddha: Their Lives, Their Works, Their Legacy. Boston: Wisdom Publications.

Pe Maung Tin, and Gordon H Luce. 1920. The Shwegugyi Inscription, Pagan 1141 AD. Journal of the Burma Research Society 10: 67-74.

Rhys Davids, Thomas William, and William Stede. 1995. The Pali Text Society's Pali-English Dictionary. Oxford: Pali Text Society.

Roodenburg, Herman, and Pieter Spierenburg. 2004. Social Control in Europe, 1500-1800. Ohio: Ohio State University Press.

Schoeber, Juliane. 2008. Communities of Interpretation in the Study of Religion in Burma. Journal of Southeast Asian Studies 39: 255-67. [CrossRef]

Solomon, Robert C. 1995. The Cross-cultural Comparison of Emotion. In Emotions in Asian Thought. Edited by Joel Marks and Roger T. Ames. Albany: State University of New York Press.

Sorensen, Joseph T. 2012. Poetic Sequsence as Personal Salvation: Saigyo's Poems "Upon Seeing Pictures of Hell”. Japanese Language and Literature 46: 2-45.

Walker, Trent. 2018. Samvega and Pasada, Dharma Songs in Contemporary Cambodia. Journal of the International Association of Buddhist Studies 41: 271-325.

Win, Than Tun. 1992. Pali and Sanskrit Loans in Myanmar Language, Pagan Period. Mater's Thesis, Tokyo University of Foreign Studies, Department of Southeast Asian Studies, Tokyo, Japan.

Yian, Geok Goh. 2015. Southeast Asian Images of Hells: Transmission and Adaptation. Bulletin de l'Ecole Francaise d'Extreme Orient 101: 91-116. [CrossRef]

(C) 2020 by the author. Licensee MDPI, Basel, Switzerland. This article is an open access article distributed under the terms and conditions of the Creative Commons Attribution (CC BY) license (http://creativecommons.org/licenses/by/4.0/). 